\title{
Republic of Poland: 2007 Article IV Consultation-Staff Report; Staff Supplement; Public Information Notice on the Executive Board Discussion; and Statement by the Executive Director for the Republic of Poland
}

Under Article IV of the IMF's Articles of Agreement, the IMF holds bilateral discussions with members, usually every year. In the context of the 2007 Article IV consultation with the Republic of Poland, the following documents have been released and are included in this package:

- $\quad$ the staff report for the 2007 Article IV consultation, prepared by a staff team of the IMF, following discussions that ended on January 21, 2008, with the officials of the Republic of Poland on economic developments and policies. Based on information available at the time of these discussions, the staff report was completed on March 19, 2008. The views expressed in the staff report are those of the staff team and do not necessarily reflect the views of the Executive Board of the IMF;

- $\quad$ a staff supplement of April 9, 2008 updating information on recent developments;

- $\quad$ a Public Information Notice (PIN) summarizing the views of the Executive Board as expressed during its April 16, 2008 discussion of the staff report that concluded the Article IV consultation; and

- $\quad$ a statement by the Alternate Executive Director for the Republic of Poland.

The document listed below has been or will be separately released.

Selected Issues Paper

The policy of publication of staff reports and other documents allows for the deletion of market-sensitive information.

To assist the IMF in evaluating the publication policy, reader comments are invited and may be sent by e-mail to publicationpolicy@imf.org.

Copies of this report are available to the public from

International Monetary Fund • Publication Services

$70019^{\text {th }}$ Street, N.W. • Washington, D.C. 20431

Telephone: (202) 623-7430 • Telefax: (202) 623-7201

E-mail: publications@imf.org • Internet: http://www.imf.org

Price: $\$ 18.00$ a copy

\section{International Monetary Fund Washington, D.C.}





\title{
INTERNATIONAL MONETARY FUND
}

\section{REPUBLIC OF POLAND}

\section{Staff Report for the 2007 Article IV Consultation}

\author{
Prepared by the Staff Representatives for the 2007 Consultation \\ with the Republic of Poland
}

Approved by Michael Deppler and Adnan Mazarei

March 19, 2008

\section{Executive Summary}

Growth is slowing and core inflation rising. Supply-side constraints are emerging, with real wages growing well above productivity. GDP growth is set to ease from $6 \frac{1}{2}$ to 5 percent in 2008 , while inflation is projected to remain outside the upper end of the band in 2008-09.

Policy tightening is warranted. Monetary policy should retain a tightening bias to prevent higher inflation expectations from becoming entrenched and a prolonged tightening bias from causing excessive appreciation in the future. The 2008 budget will, at best, be neutral, but the government plans to cut the structural deficit by about $1 / 2$ percent of GDP annually over the medium-term. This will help safeguard external sustainability and maintain the zloty within its equilibrium range as the current account deficit otherwise will approach the limit of what is safe. Staff suggest a threeyear fiscal framework to protect against pro-cyclical policy and broaden support for fiscal targets.

There is no evidence of the current turmoil spilling over through financial channels. Banks are very profitable, have scant exposure to US sub-prime assets and structured products, and the corporate bond market is small. While systemic vulnerabilities are limited, the unification of supervision comes at a sensitive time and vigilance is needed during the transition period.

Automatic stabilizers should be allowed to work. Downside risks arising from the possibility of stronger-than-expected external spillovers are broadly offset by risks that domestic demand will be more robust than assumed. Should downside risk materialize, monetary tightening should pause and the fiscal stabilizers should be allowed to work.

Boosting labor participation is essential for long-term growth prospects. Participation is low and the scope for increasing utilization is being exhausted. Reforming generous provisions for early retirement and for disability payments is of highest priority, and reducing the tax wedge at lower incomes and reforming the agricultural pension system could also boost participation.

The authorities will set a timetable for euro adoption once they deem that the conditions for success have been established. 


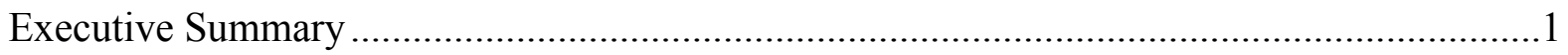

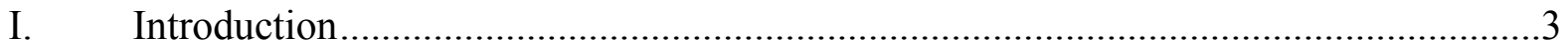

II. Strong Growth Continued in 2007, But Bottlenecks Have Emerged .............................3

A. Recent Economic Developments .........................................................................

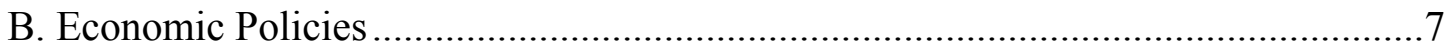

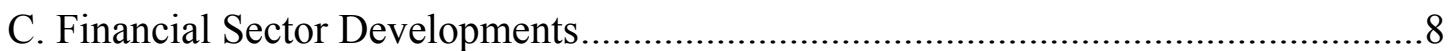

III. Outlook: Gradually Slowing Output Growth, But Inflationary Risks Remain.............10

IV. Should the Monetary Policy Tightening Cycle Continue? ..........................................12

V. Sustained Fiscal Consolidation Required ..............................................................12

VI. Limited Financial Sector Vulnerabilities and Supervision ........................................15

VII. Enhancing Growth and Flexibility, and Euro Adoption ..............................................16

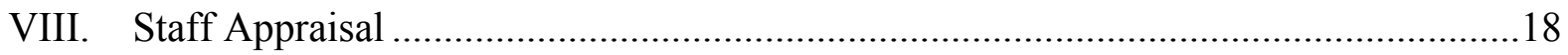

Boxes

1. Macroeconomic Effects of European Union Transfer to the New Member States (NMS)................................................................................14

2. What Can Poland Learn from Other EU Countries Regarding Labor

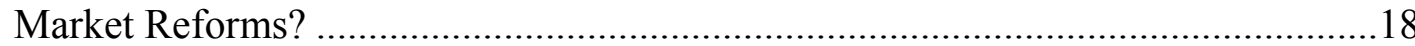

Figures

1. Poland and Other Emerging European Countries: Private Credit, 2000-06 _...............21

2. Poland and Other EU Countries: Labor Market Indicators, 1980-2006 .....................22

3. Poland and Other CEE Countries: Real and Nominal Convergence

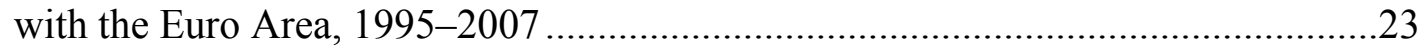

4. External Debt Sustainability: Bound Tests ........................................................24

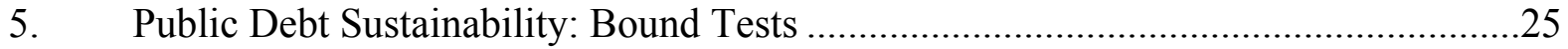

Tables

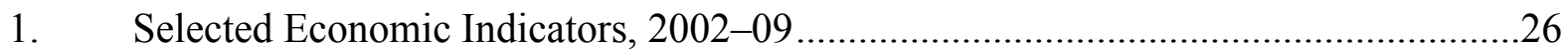

2. Balance of Payments on Transaction Basis, 2004-2013 ………….........................27

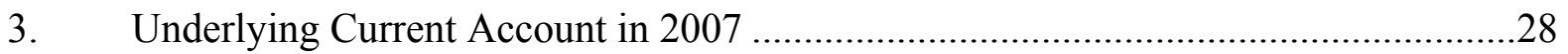

4. External Debt Sustainability Framework, 2002-2012 …………………….............29

5. General Government Revenues and Expenditures, 2002-09 ......................................30

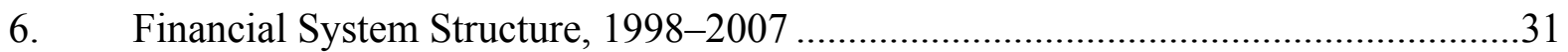

7. The Core Set of Financial Soundness Indicators for Banks, 1998-2007 ....................32

8. Encouraged and Other Financial Soundness Indicators, 1998-2007...........................33

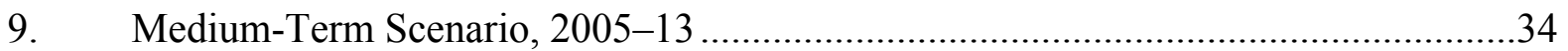

10. Public Sector Debt Sustainability Framework, 2002-2012 ……………..................35

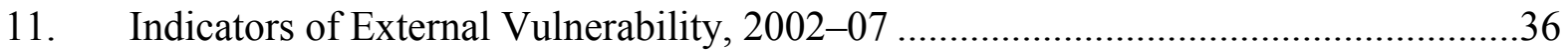




\section{INTRODUCTION ${ }^{1}$}

1. Poland is experiencing strong and well-balanced growth, in large part because of rapid financial deepening and an EU accession related investment boom. So far, the recovery has resulted in only limited upward pressure on core inflation and the external current account deficit. Similarly, the zloty remains within the estimated equilibrium range.

2. Resource constraints are, however, beginning to emerge, especially in the labor market, where real wage growth has outpaced productivity for some time. The recent steady increase in core inflation suggests that scope for continuing to absorb unit labor costs (ULCs) by squeezing profit margins is diminishing. And with limited observed spillovers thus far from the slowdown in major industrial countries, GDP growth is set to remain at or above potential, increasing the risk of a wage-price spiral. Cost pressures could also erode competitiveness and lead to a faster deterioration in the current account than seen in recent years.

3. Against this background, discussions with the newly elected government focused on the dual challenge of containing demand pressures and strengthening the economy's supply response. As to the former, the main topics included spillovers from the financial market turmoil, the appropriate near-term monetary and fiscal policy stance, and the need for fiscal consolidation over the medium term. On the supply side, the focus was on the role of the financial sector, the scope for boosting Poland's exceptionally low labor participation, and the prospect for accelerating catch-up gains in productivity through liberalization and privatization. Discussions also focused on the frameworks for fiscal policy and financial sector supervision.

\section{Strong Growth Continued in 2007, But Bottlenecks Have Emerged}

\section{A. Recent Economic Developments}

\section{After years of sluggish performance, Poland enjoyed a second year of strong} economic growth in 2007 (Table 1). The upturn has been underpinned by robust and wellbalanced growth as EU accession has bolstered business confidence and spurred a longawaited rise in investment. Meanwhile, private consumption has remained strong, driven by rapidly rising real wages, increasing employment, and record-high credit growth, but also tax cuts. The external sector, however, has become an increasing drag on the economy since mid-2006. This, and incipient signs of a gradual slowing in GDP growth, likely reflect emerging capacity constraints.

\footnotetext{
${ }^{1}$ A team comprising of Mr. Thomsen (head), Mr. Hoffmaister, Ms. Allard, and Mr. Annett (all EUR) and Mr. Galizia (MCM) visited Warsaw during January 14-21, 2008; an advance team arrived on January 9. Messrs. Rosenberg and Sierhej, from the Warsaw Regional Office, supported the work of the mission. Poland is an Article VIII country (Appendix I). Data provision is adequate for surveillance (Appendix II).
} 

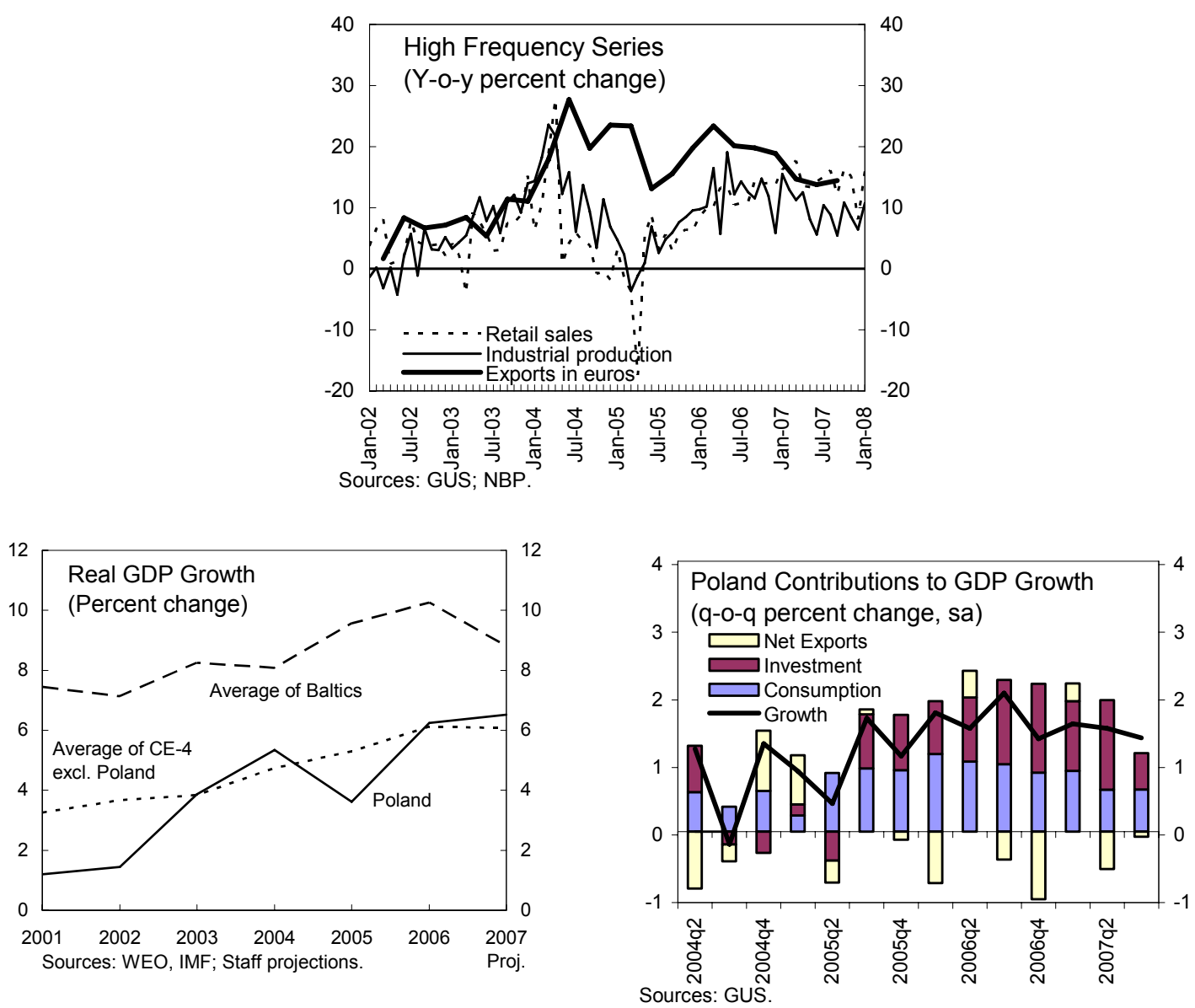

5. The output gap is closing and labor markets are tightening. Capacity utilization indicators have reached record-high levels, and staff estimates that GDP growth is still running above potential, despite the rise in investment in recent years. Pressures are particularly evident in labor markets. Driven by plummeting unemployment, wage growth reached close to 10 percent in the fourth quarter (year-on-year), and real wage growth continues to significantly outstrip productivity gains. Labor shortages have been compounded by continuous emigration to Western Europe since EU accession.
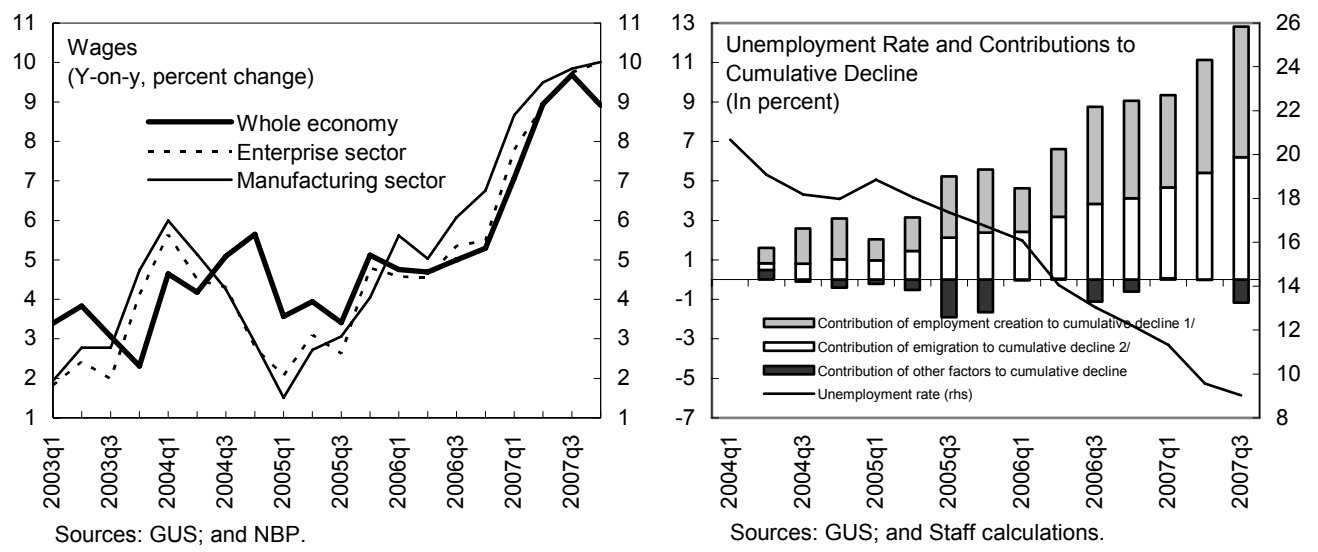

Sources: GUS; and NBP.

$1 /$ Assuming half of the new jobs are filled with previously unemployed people.

2/ Assuming 1.5 million Poles emigrated since May 2004, out of which 60 percent were previously unemployed. 
6. Demand pressures are beginning to affect inflation. Headline CPI inflation has been increasing since 2006, reaching 41/4 percent (year-on-year) in January 2008, despite some appreciation of the zloty. This lies not only well above the National Bank of Poland's (NBP's) inflation target of $2 \frac{1}{2}$ percent, but also above the $1 \frac{1}{2}-31 \frac{1}{2}$ percent band. Until the Fall of 2007, this increase almost entirely reflected soaring food and energy prices, and core inflation remained stable as rising ULCs were absorbed by lower profit margins, which had been boosted by wage restraint in the first half of the decade. Core inflation has edged up during the last six months, suggesting that the scope for squeezing profit margins is narrowing. Consistent with this, market-based indicators suggest that inflation expectations remained well-anchored through most of 2007, but began to pick up toward the end of the year.
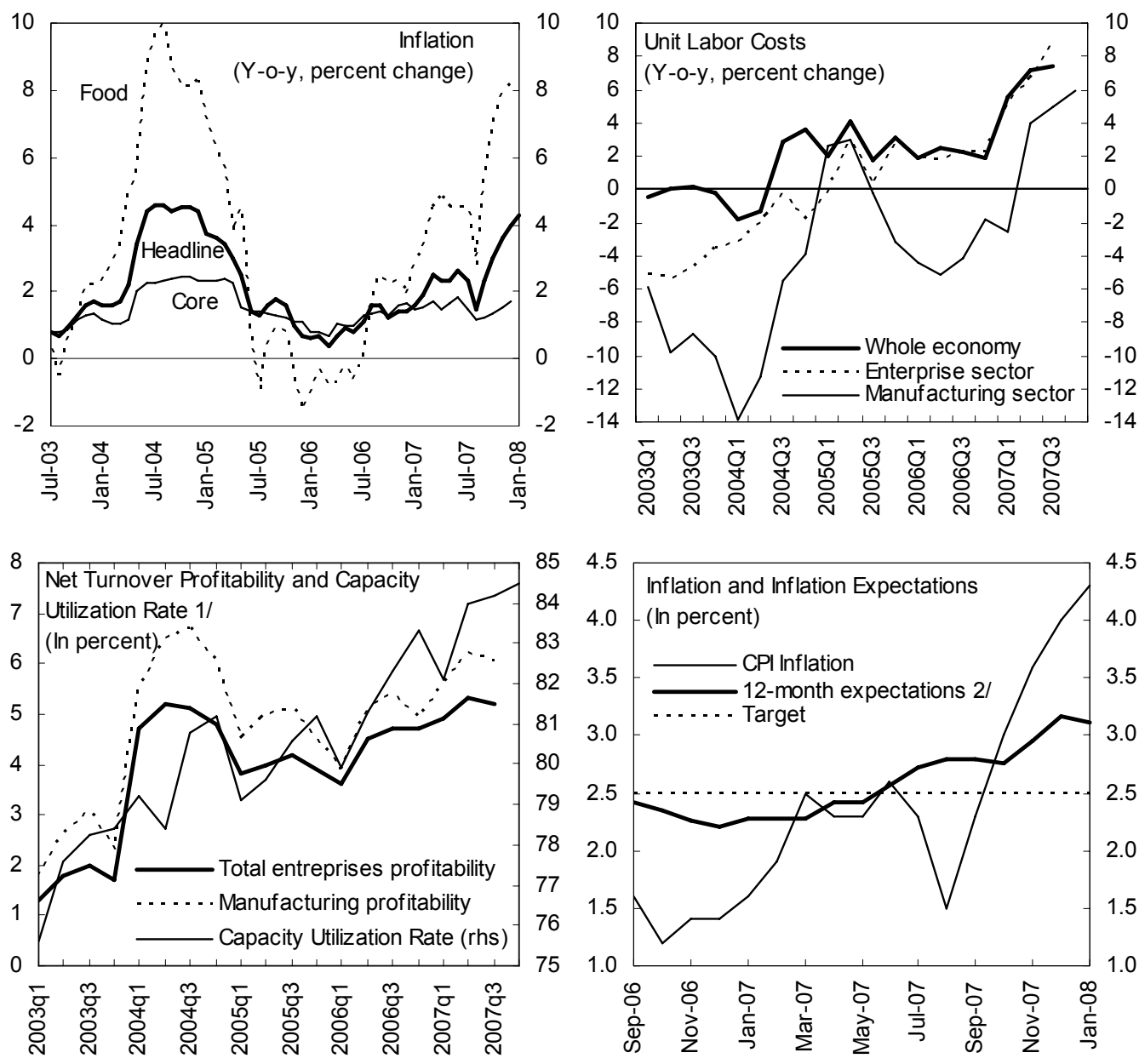

Sources: GUS; NBP; Bloomberg; Staff calculations.

$1 /$ Net profit in percent of turnover.

2/ Derived from inflation-indexed Treasury. 


\section{Despite demand pressures, the current account deficit is still relatively low and} the zloty is within the estimated equilibrium range. Buoyant imports have resulted in a slight widening of the deficit - to about $33 / 4$ percent of GDP in 2007 - even as Poland has continued to gain export market share and remittances have grown. However, the deficit has remained fully financed by record levels of FDI, and the estimated underlying deficit of $4 \frac{1}{2}$ to 6 percent of GDP in 2007 is consistent with external sustainability inasmuch as it remains below the estimated debt-stabilizing level of 6 percent of GDP (Tables 2, 3, and 4). ${ }^{2}$ Furthermore, staff estimates of the equilibrium real exchange rate do not point to misalignment, despite the real appreciation that has taken place since mid$2006 .{ }^{3}$

\begin{tabular}{lrrrrr}
\multicolumn{7}{c}{$\begin{array}{c}\text { Poland: Export Margin, 2003-07 } \\
\text { (Year-on-year rate of change) }\end{array}$} & & \\
\hline & 2003 & 2004 & 2005 & 2006 & $\begin{array}{r}2007 \\
\text { proj. }\end{array}$ \\
\hline Export margin & & & & & -2.6 \\
Exports deflator & 6.3 & 7.5 & -5.3 & 0.2 & -2.6 \\
Unit labor cost & 6.2 & 8.3 & -2.5 & 2.3 & 3.8 \\
Relative profitability of exports 1. & 5.9 & 4.2 & -5.2 & 0.8 & 1.0 \\
Exports deflator & 6.2 & 8.3 & -2.5 & 2.3 & 3.8 \\
GDP deflator & 0.4 & 4.1 & 2.6 & 1.5 & 2.8 \\
\hline Source: IMF, WorddEconomic Outlook. & & & & & \\
1/ Assumes a common unit labor cost for the economy. & & &
\end{tabular}

Balance of Payments, 2005-07 (In billions of US \$)

\begin{tabular}{|c|c|c|c|}
\hline & 2005 & 2006 & $\begin{array}{l}2007 \\
\text { Proj. }\end{array}$ \\
\hline Current Account Balance & -5 & -11 & -15 \\
\hline Capital and Financial Account Balance & 16 & 14 & 35 \\
\hline Net FDI & 7 & 10 & 16 \\
\hline Other Net Flows & 9 & 4 & 19 \\
\hline Errors and Omissions & -3 & -1 & -6 \\
\hline Reserve Accumulation & 8 & 2 & 13 \\
\hline \multicolumn{4}{|l|}{ Memo item: } \\
\hline Current Account in percent of GDP & -1.6 & -3.2 & -3.7 \\
\hline
\end{tabular}

Sources: NBP, Staff projections.

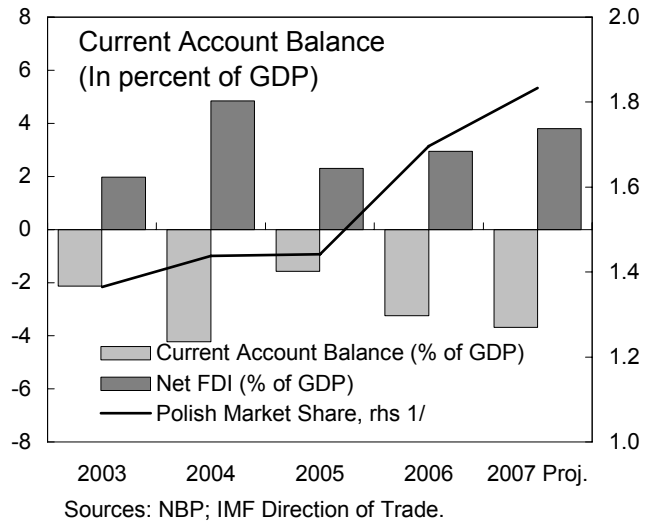

1/ Data as of $2007 q 3$.

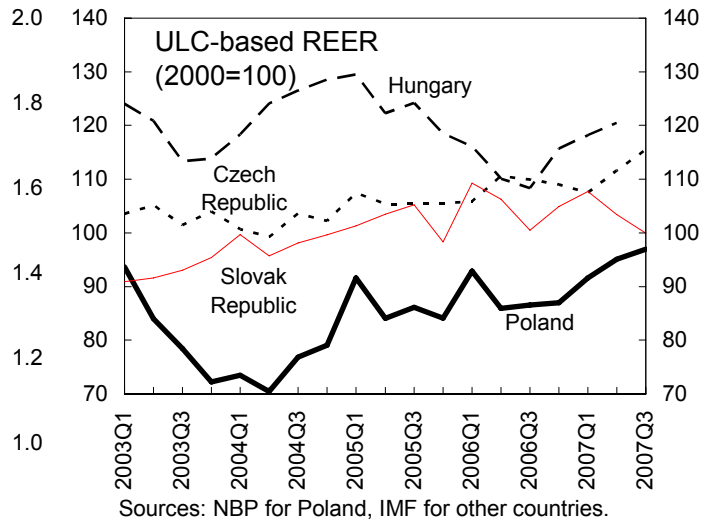

\footnotetext{
2 The underlying current account balance is defined as the balance that would result, at prevailing market exchange rates, if all countries were operating at their respective potential output levels. It is estimated using trade equations. The methodology is described in Bayoumi and Faruquee, 1998, Chapter V of "Exchange Rate Assessment, Extensions of the Macroeconomic Balance Approach,” IMF Occasional Paper 167.

${ }^{3}$ This assessment draws on preliminary CGER estimates suggesting that the estimated deviations from the equilibrium real exchange rate are within the margin of error of the estimation.
} 


\section{B. Economic Policies}

\section{Adjusting for cyclical factors, there was a fiscal tightening of about $3 / 4$ percent of} GDP in 2007 (Table 5). Expenditures were below budgeted limits at both state and local levels, an under-execution that largely reflected difficulties in carrying out public investments, including those related to EU funds. At the same time, strong cyclically-driven tax collections contributed to a substantially lower-than-budgeted general government deficit of $2 \frac{1}{2}$ percent of GDP, a full $1 / 2$ percent of GDP below the 2007 Convergence Program target.

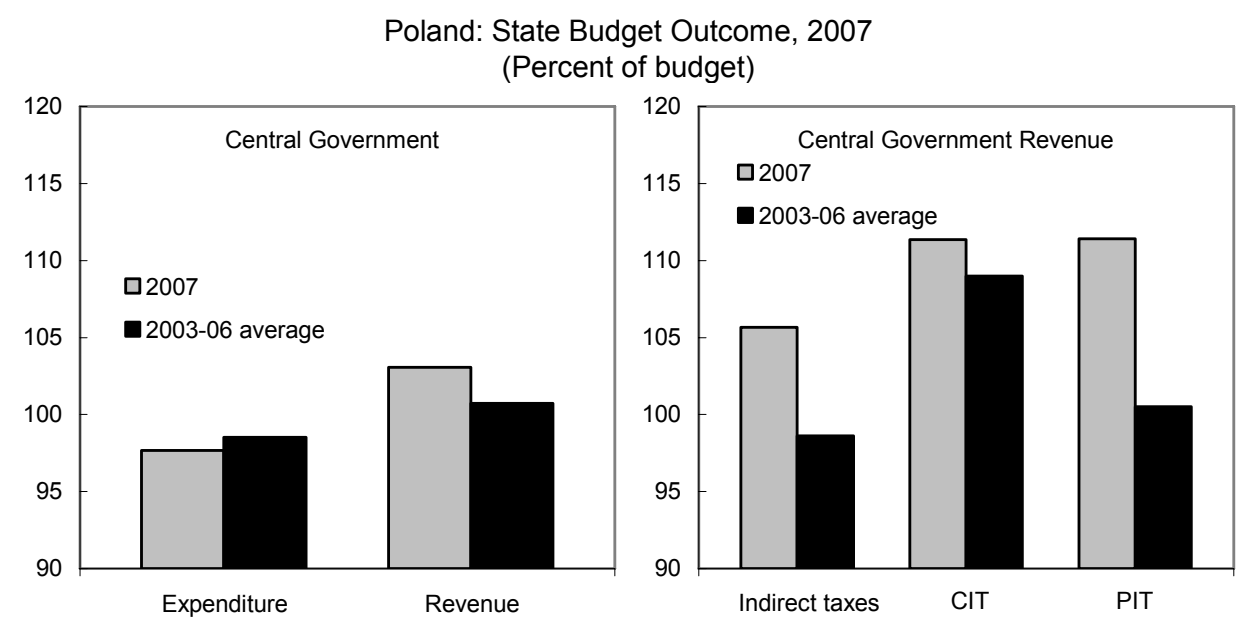

Source: Ministry of Finance.

Poland: Summary General Government Balance, 2006-07 (In percent of GDP)

\begin{tabular}{lcr}
\hline & 2006 & $\begin{array}{r}2007 \\
\text { Est. }\end{array}$ \\
\hline General government revenue & 39.8 & 41.3 \\
General government expenditure 1/ & 43.8 & 43.9 \\
General government balance 1/ & -4.0 & -2.6 \\
Memorandum items: & -3.2 & -2.4 \\
Structural balance 2/ & \\
\hline Sources: Polish authorities; and IMF staff estimates and projections. \\
1/ Fund definition (including the cost of the pension reform). \\
2/ Actual balance corrected for economic cycle.
\end{tabular}

9. A monetary tightening cycle is underway. Reflecting the Monetary Policy Council's (MPC)'s concern about rising inflation, policy interest rates have been raised six times since April 2007 and now stand at 51/2 percent. Simultaneously, the zloty has appreciated in response to a widening spread of domestic interest rates over euro and dollar interest rates. Nonetheless, monetary conditions have loosened, as the increase in nominal rates have not prevented real interest rates from falling in the face of accelerating inflation. Besides liquidity management operations (including repos), the NBP has continued 
to refrain from directly intervening in foreign exchange markets although international reserves have increased since 2004 as a result of EU transfers and re-evaluation.
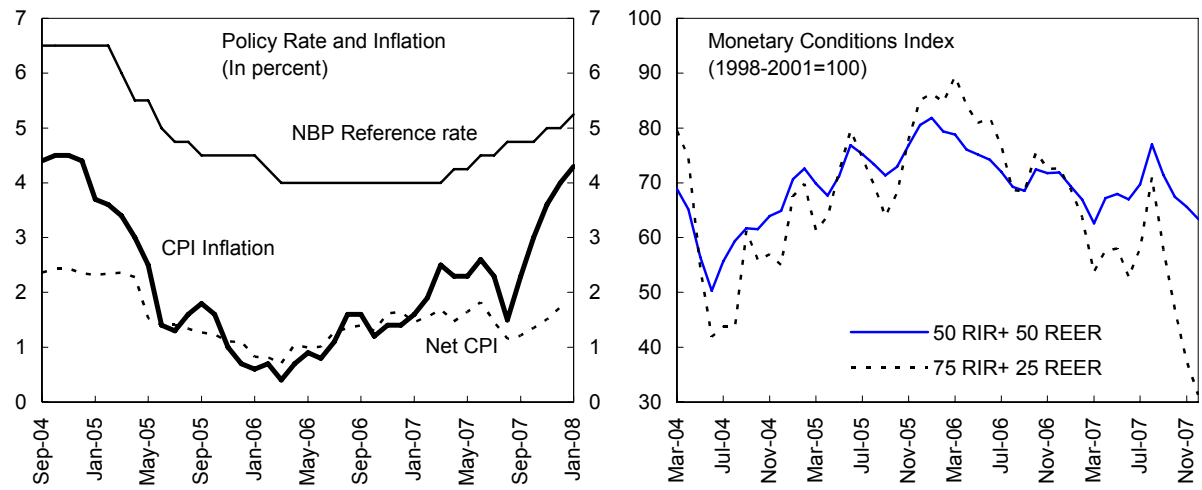

Sources: GUS; NBP; Staff calculations.

\section{Financial Sector Developments}

10. The impact of the international capital market turmoil has been limited so far.

The banking sector's profitability has remained high and it has little, if any, exposure to U.S. sub-prime mortgage assets. Foreign capital inflows have held up well, and the increases in both credit default swap and bond spreads have been limited, especially in relation to other European emerging markets. In contrast, the stock market retrenchment in Poland has been more severe, following substantially larger gains than elsewhere in the region since 2006.

\begin{tabular}{lcccc}
\hline \multicolumn{5}{c}{ Selected Financial Indicators } \\
\hline & $\begin{array}{l}\text { Poland } \\
(2007)\end{array}$ & $\begin{array}{c}\text { Czech } \\
\text { Republic } \\
(2006)\end{array}$ & $\begin{array}{c}\text { Hungary } \\
(2006)\end{array}$ & $\begin{array}{c}\text { Western } \\
\text { Europe 1/ } \\
(2006)\end{array}$ \\
\hline $\begin{array}{l}\text { Return on equity } \\
\text { Return on assets }\end{array}$ & 23.7 & 23.1 & 22.9 & $7.5-15.6$ \\
$\begin{array}{l}\text { Foreign currency } \\
\text { denominated liabilities } \\
\text { to total liabilities }\end{array}$ & 1.8 & 1.3 & 1.8 & $0.3-0.8$ \\
\hline
\end{tabular}

1/ Western Europe comprises, France, Germany, Italy, and the UK. Sources: GFSR, IMF; and country authorities.

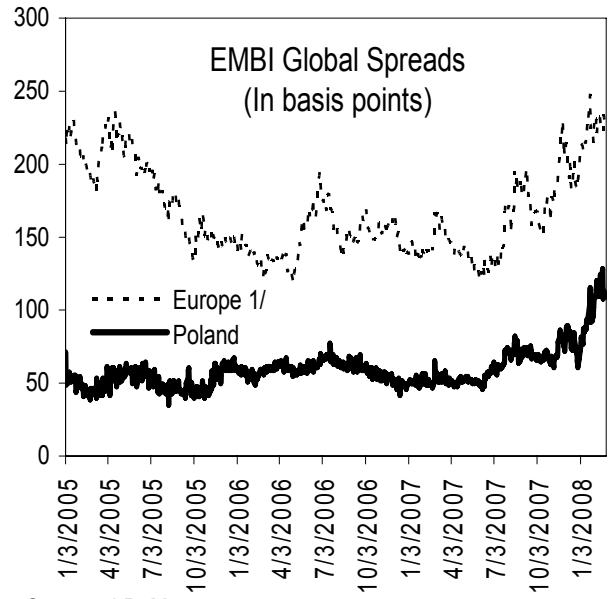

Source: J.P. Morgan

1/ Comprises Bulgaria, Hungary, Kazakhstan, Poland, Russia, Serbia, Turkey, and Ukraine.

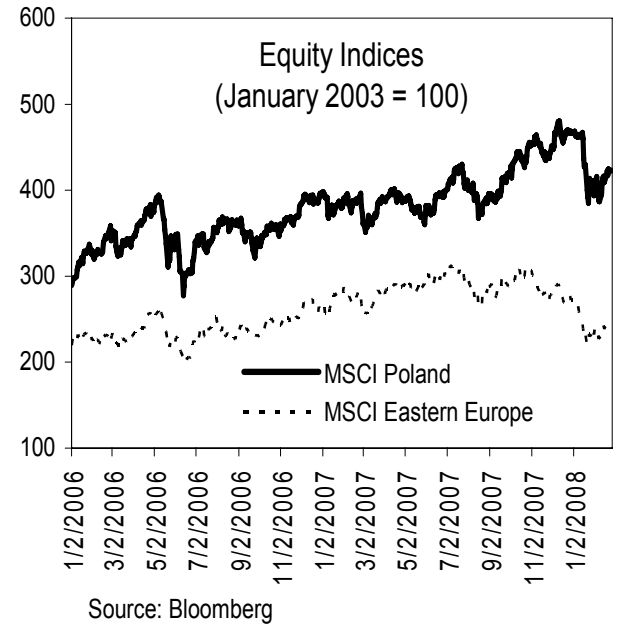


Government Bond and Stock Market, CE-4

(February 1, 2007 - February 15, 2008)
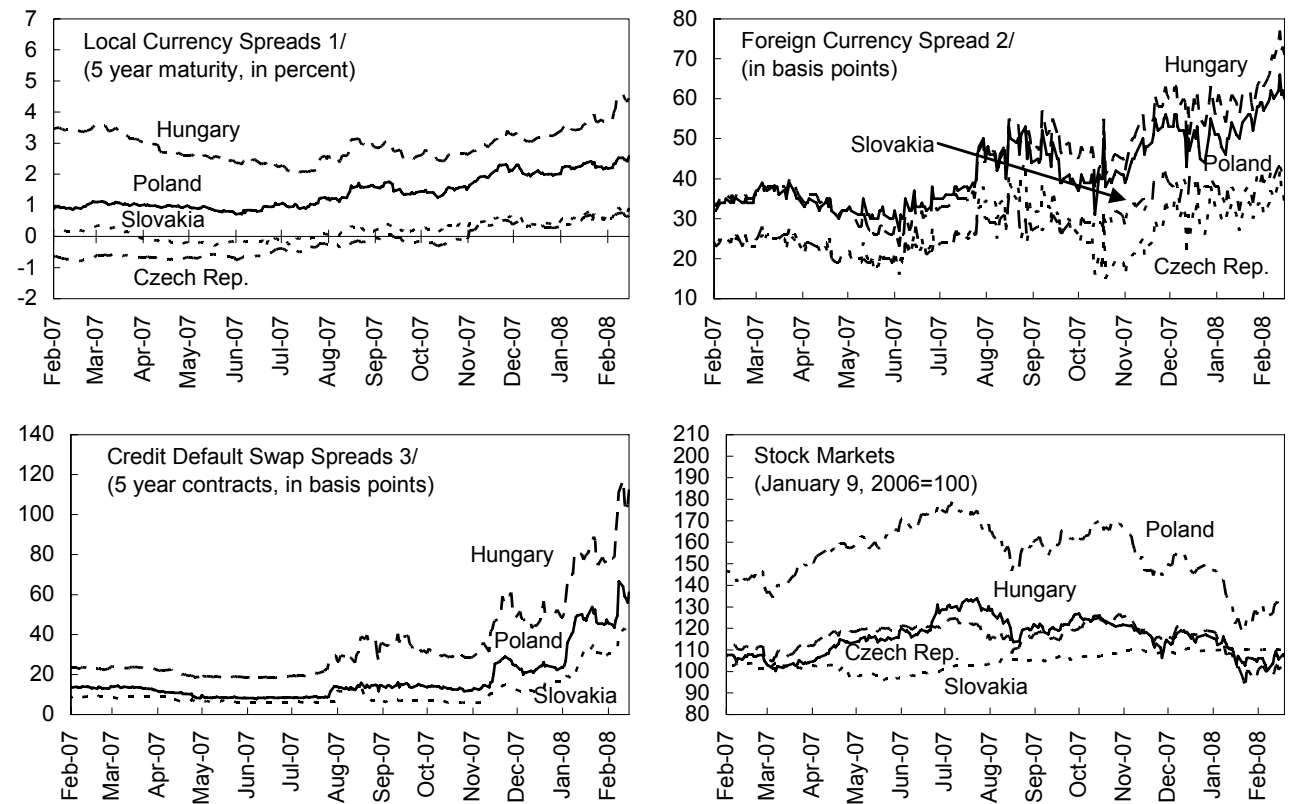

Source: Bloomberg.

1/ Spread of 5-year local currency government bond versus 5-year Bund.

2/ JP Morgan Euro EMBI Global government spreads.

$3 /$ The credit default swap (CDS) is an over-the-counter contract whereby the buyer pays the seller a periodic fee in return for a contingent payment by the seller upon default of the issuer of a credit instrument. The fee is the spread time the face value of the bond.

11. Credit growth remains strong. The fastest growth is taking place in the mortgage market, where a rapidly rising number of households are benefiting from first-time access to mortgage credit (Figure 1). But while mortgage growth is slowing, markets for enterprise and consumer loans remain strong. After years of deleveraging, corporate credit growth has also resumed, reflecting the buoyancy of investment. While corporate and mortgage interest rates have increased in line with policy rates, interest rates on consumer loans have declined, reflecting heightened competition in a segment of the market that still offers banks relatively high risk-adjusted returns. Whereas the banking system was increasing its net foreign assets until 2006 — as foreign-owned

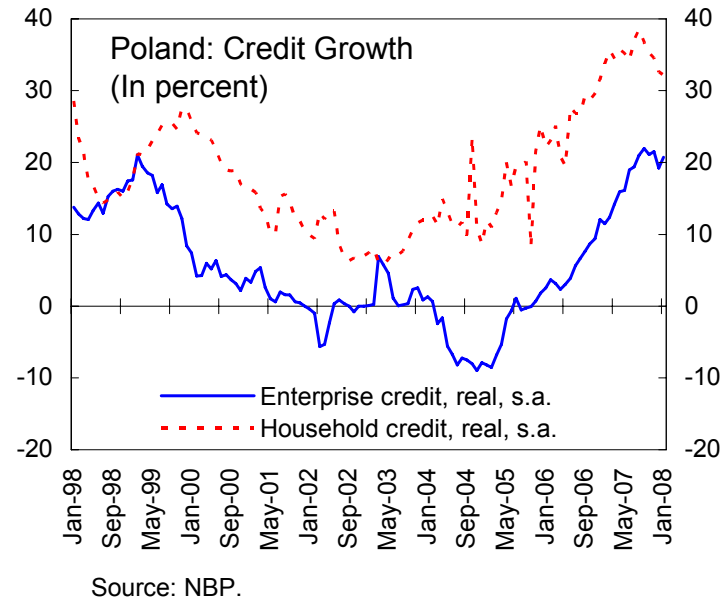


local banks were net lenders to their parent groups - domestic credit has been increasingly funded from abroad, consistent with the rising interest differential in favor of the zloty.
Sources of Growth in Net Domestic Assests, 2005-07

(Changes in terms of net domestic assets, in percent)

\begin{tabular}{lrrr}
\hline & 2005 & 2006 & $\begin{array}{r}2007 \\
\text { Prel. }\end{array}$ \\
\hline Growth in Net Domestic Assets & 8.0 & 30.2 & 34.3 \\
Growth in Broad Money & 21.3 & 27.2 & 20.3 \\
Growth in Net Foreign Liabilities & -13.3 & 3.0 & 14.1 \\
\hline Sources: NBP, Staff estimates. & & &
\end{tabular}

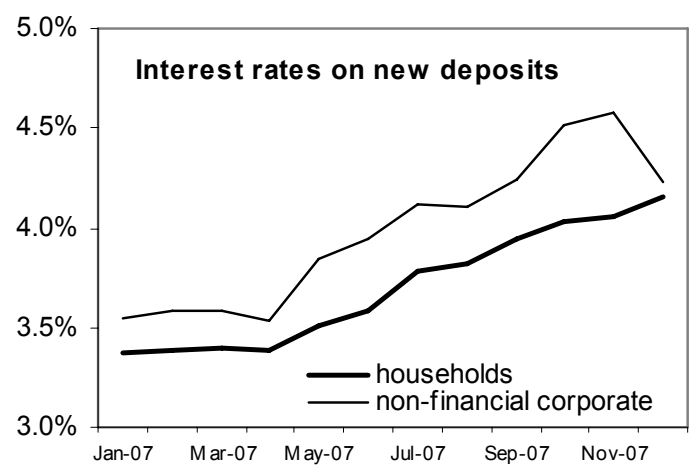

Source: NBP

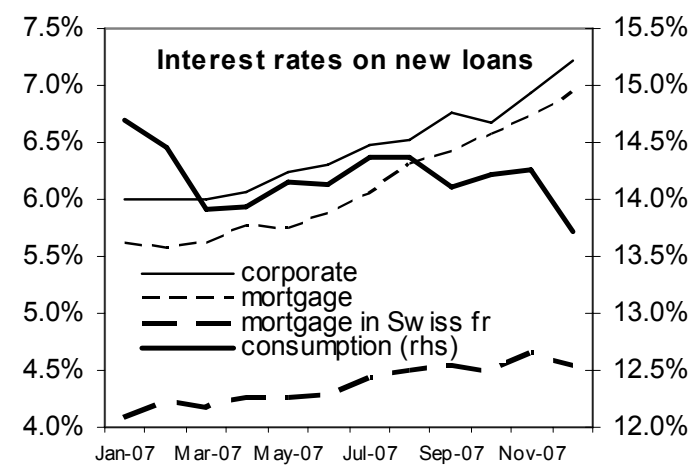

\section{OUtlook: Gradually Slowing OUTPUT GroWth, BUt Inflationary RiSks REMAIN}

12. Economic growth is expected to continue to ease in 2008. Staff and the authorities agreed that the slowdown evident in the data would continue. Staff's baseline scenario shows growth slowing to 5 percent, compared to the authorities' projection of 5-5 $\frac{1}{2}$ percent. In addition to base effects, the further slowdown reflects weaker export markets and a tightening of domestic resource constraints. As to the latter, with real wage growth set to continue to outstrip productivity gains and with some evidence that there is only limited scope for further squeezing profit margins, staff expects investment growth to gradually Potential and Output Growth and the Output Gap, 2004-08

\begin{tabular}{lrrrrr}
\hline & 2004 & 2005 & 2006 & 2007 & 2008 \\
\hline The Authorities' Estimates & & & & & \\
$\quad$ Potential Growth & 4.2 & 4.8 & 5.3 & 5.5 & 5.6 \\
$\quad$ Output Growth & 5.3 & 3.6 & 6.2 & 6.5 & 5.5 \\
$\quad$ Output Gap & -0.1 & -1.2 & -0.4 & 0.5 & 0.4 \\
Staff's Estimates & & & & & \\
$\quad$ Potential Growth & 4.3 & 4.5 & 4.5 & 4.6 & 4.7 \\
$\quad$ Output Growth & 5.3 & 3.6 & 6.2 & 6.5 & 4.9 \\
$\quad$ Output Gap & -3.2 & -4.0 & -2.4 & -0.6 & -0.4 \\
\hline Source: Ministry of Finance; and Fund staff estimates. &
\end{tabular}

moderate. The authorities are somewhat more optimistic about the remaining slack in the labor market. In terms of the output gap, staff projects it to narrow for a third year, with only a marginal increase in potential growth to $43 / 4$ percent; the authorities foresee little change, reflecting their assumption of higher potential growth.

Poland's Outlook, 2007-08

\begin{tabular}{lcc}
\hline & 2007 & 2008 \\
\hline GDP Growth & 6.5 & 4.9 \\
Inflation (period average) & 2.5 & 3.8 \\
Current Account Balance & -3.7 & -4.9 \\
Memo item: & & \\
Euro Zone GDP Growth & 2.6 & 1.6 \\
\hline
\end{tabular}

Sources: WEO, IMF; and Fund staff projections. 
13. Inflationary pressures will remain high, and could possibly increase. Pressures on prices are expected to remain elevated, despite the growth slowdown, in line with emerging supply-side constraints under the baseline scenario. Upward pressures could be magnified by secondary effects from the large food and energy price increases last year still in the pipeline. In view of these considerations, staff projects that, absent further tightening, inflation will systematically exceed the upper end of the plus/minus 1 percent inflation band round the NBP's central inflation target in 2008-09. NBP projections also show such an overshooting.

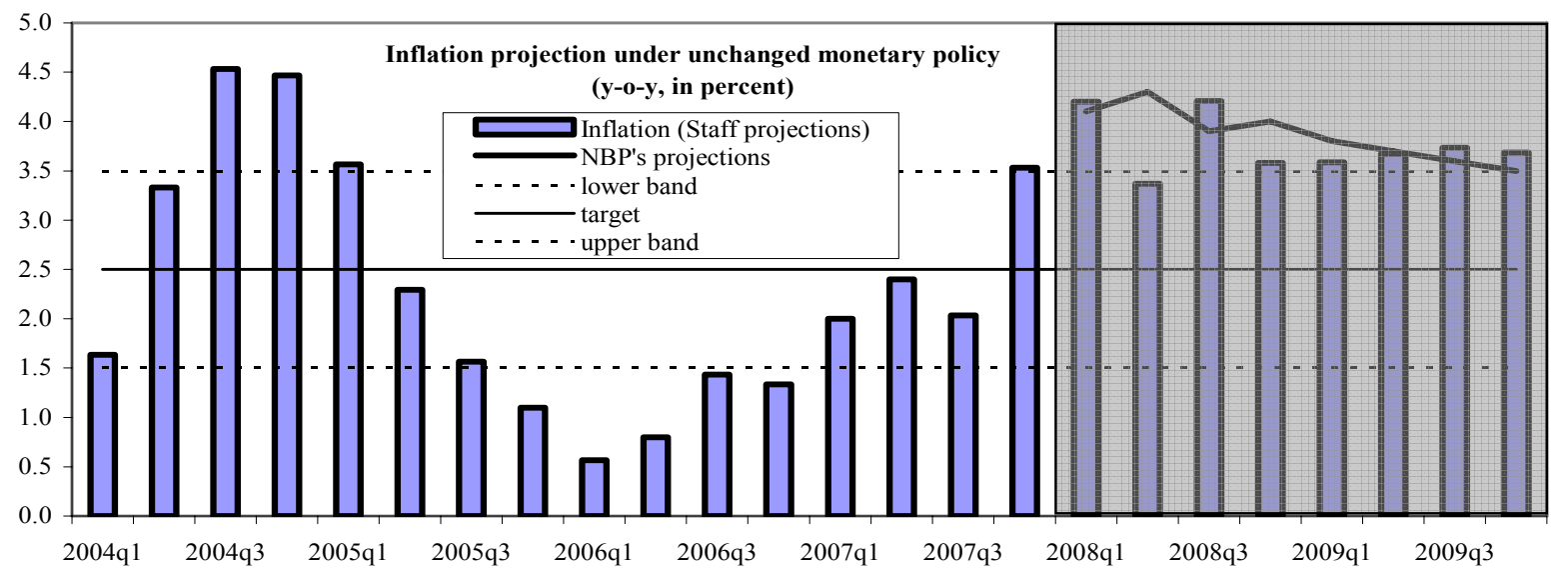

Sources: NBP Inflation Report; Staff projections.

\section{The outlook for growth is subject to increasing uncertainty, but risks appear}

equally balanced. Staff agrees that there is some upside risk stemming from the possibility that investments will not slow as much in face of cost pressures as assumed in the baseline scenario. On the other hand, downside risks - arising from the possibility of larger-thanexpected spillovers from the weakening external environment, through both real and financial channels - are also clearly present. At this juncture, staff believes that these risks are broadly balanced, and that the problem already evident in the data of gradually emerging resource constraints, with decelerating growth and accelerating core inflation, will most likely remain the key challenge facing policy makers. This assessment drives staff's recommendations to tighten policies, as discussed below. Clearly, should the aforementioned downside risks materialize - to such an extent that stronger-than-expected negative external spillovers cause growth to fall below potential and inflationary pressures to ease - a pause in the tightening cycle of monetary policy would be warranted. In that case, there would also be scope for some fiscal support to activity, by allowing the automatic fiscal stabilizers to operate.

\section{Looking to the medium term, the external current account deficit is expected to} widen (Table 9). While the deficit is currently well contained - and the zloty is within its equilibrium range - it is projected to gradually increase but remain below the upper limit of what is safe. In this regard, however, the experience of other countries in the region suggests that some downside risks, especially if consumption growth fails to moderate. This could be the case if expectations of persistently large income gains and increased access to consumer 
financing, possibly fueled by large capital inflows, trigger greater consumption smoothing. The additional fiscal consolidation discussed below would thus serve to reduce external vulnerabilities.

\section{Should the Monetary Policy Tightening Cycle Continue?}

\section{There were divergent views within the MPC on the need for further tightening} of monetary policy. Among those favoring a pause, the main considerations included relatively more optimistic assumptions about potential growth, the lagged impact of the recent increases in policy rates, and the risk of stronger negative spillovers from the weakening external environment. Opponents of a pause were less optimistic about potential growth, and saw the recent increase in core inflation as a sign of an emerging wage-price spiral in the face of tightening labor market constraints.

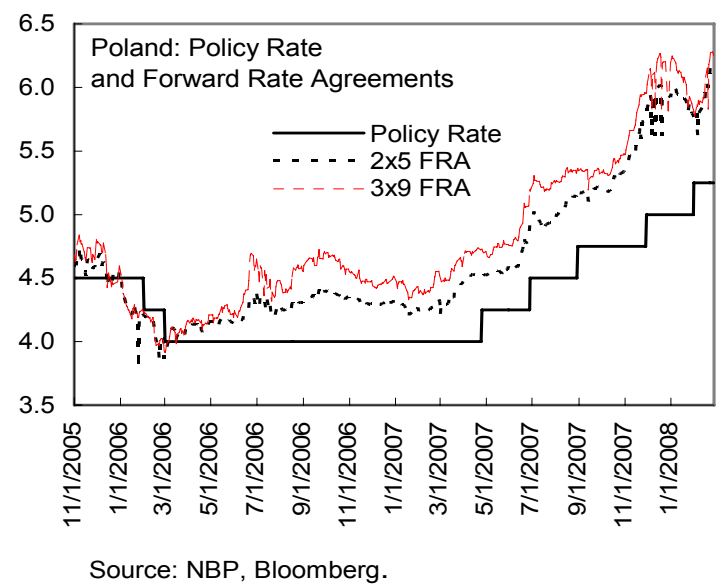

\section{Staff felt that, on balance, a continuation of the tightening cycle was warranted} at this time. This was in line with the baseline scenario's assumption of increasing resource constraints. Staff was particularly concerned that the emergence of a wage-price spiral was heightening the risk of increased inflation becoming entrenched in inflation expectations. In this regard, it warned that the entrenchment of inflation around the upper end of the band could fuel market expectations of a prolonged tightening bias, triggering additional capital inflows and attendant upward pressures on the zloty. In advocating a tightening, staff was guided by the assessment that the international capital market turmoil will neither prompt a major tightening of monetary conditions nor pose any significant risks to the banking system.

\section{Sustained Fiscal Consolidation REQUiRed}

18. The 2008 budget implies a small fiscal stimulus. On unchanged policies, and predicated on staff's baseline growth scenario, the budget submitted to parliament by the previous administration implies a widening of the fiscal deficit in 2008 by about $1 / 4$ percent of GDP as the continued buoyancy of fiscal revenues is more than offset by a number of expansionary measures. There was agreement that this stimulus was unfortunate under the current circumstances. The authorities explained, however, that exacting constitutional deadlines meant that only minor corrections to the inherited 2008 budget had been feasible. While they ruled out a mid-year supplementary budget and saw little scope for underexecuting expenditures, they were confident of a better-than-budgeted outcome on account of continued revenue buoyancy, suggesting that any fiscal stimulus would be small. 
Poland: Summary State Budget, 2007-08 1/

(In percent of GDP)

\begin{tabular}{lccc}
\hline & \multicolumn{2}{c}{2007} & 2008 2/ \\
\cline { 2 - 3 } & Budget & Estimated & Projected \\
\hline Revenues & \multicolumn{3}{c}{ (in percent of GDP) } \\
Expenditures & 19.7 & 20.5 & 22.6 \\
Balance & 22.3 & 22.0 & 24.9 \\
Memo items & -2.6 & -1.5 & -2.3 \\
$\quad$ & & & \\
General government balance $3 /$ & -3.6 & -2.6 & -2.9 \\
Cyclically adjusted balance & -- & -2.4 & -2.8 \\
Underlying balance & -- & -2.3 & -2.5 \\
GDP growth & 5.4 & 6.5 & 4.9 \\
\hline
\end{tabular}

Source: Ministry of Finance and staff estimates.

1/ Includes EU transfers and excludes transfers to the second pillar of the pension system.

2/ Consistent with the State budget, revenues and expenditures related to EU funds are reflected in the 2008 projection.

3/ Fund definition (including the cost of the pension reform).

19. The government intends to accelerate fiscal consolidation over the medium term, targeting a deficit of one percent of GDP by 2011. Such a target would be consistent with Poland's commitments under the Stability and Growth Pact. It would entail a reduction in the structural deficit of about $1 / 2$ percent of GDP annually, considerably more than the cumulative reduction of $3 / 4$ percent of GDP over the four-year period envisaged under the previous government's Convergence Program The authorities noted that this, in combination with stepped-up privatization, would secure a reduction in public debt of 4-7 percent of GDP by 2011.

Evolution of General Government Balance, 2008-2012

\begin{tabular}{lrrrrr}
\hline & 2008 & 2009 & 2010 & 2011 & 2012 \\
\hline I. Baseline scenario 1/ & & & & & \\
Revenue & 41.8 & 42.0 & 42.0 & 42.0 & 42.1 \\
Expenditure & 44.8 & 45.0 & 44.9 & 44.7 & 44.7 \\
Fiscal balance & -2.9 & -3.0 & -2.8 & -2.7 & -2.5 \\
Public debt & 46.1 & 46.1 & 45.8 & 45.4 & 44.8 \\
Nominal expenditure growth & 9.9 & 8.2 & 7.2 & 7.2 & 7.6 \\
Real expenditure growth & 7.3 & 5.5 & 4.5 & 4.6 & 4.9 \\
I. Adjustment scenario & & & & & \\
Revenue & & & & & \\
Expenditure & 41.8 & 42.0 & 42.0 & 42.0 & 42.1 \\
Fiscal balance & 44.8 & 44.4 & 44.0 & 43.5 & 43.1 \\
Public debt & -2.9 & -2.4 & -2.0 & -1.5 & -1.0 \\
Nominal expenditure growth & 9.9 & 6.7 & 6.8 & 6.4 & 6.6 \\
Real expenditure growth & 7.3 & 3.9 & 4.0 & 3.7 & 3.9 \\
\hline Source: Staff calculations. & & & & &
\end{tabular}

Source: Staff calculations. 
20. The fiscal consolidation will be focused on the expenditure side. The new target would be consistent with expenditure continuing to grow by about 4 percent a year. To accommodate EU-funded capital spending and the government's desire to cut taxes, however, current spending will need to slow more substantially (Box 1). Moreover, considering that non-discretionary spending amount to about 70 percent of total spending and that wages in important parts of the public sector are subject to considerable upward pressure due to shortages caused by emigration, staff noted that the consolidation would likely entail streamlining benefit programs. Senior officials acknowledged that this would be desirable, but cautioned that it was too early in the new government's term for detailed plans to have been developed and approved. They did, however, note that cutting taxes would be subordinated achieving the medium-term deficit target.

\section{Box 1. Macroeconomic Effects of European Union Transfer to the New Member States ${ }^{1 /}$}

European Union (EU) funds are poised to play a substantial role in macroeconomic outcomes of the new member states. Estimates for eight new member states (NMS) in Central and Eastern Europe - those that acceded in 2004-place EU transfers in excess of 3 percent of GDP annually during 2007-13.

Simulation results using the Fund's Global Integrated Monetary and Fiscal model (GIMF) modified to account for ongoing income catch-up in NMS - shed light on the channels though which these funds affect the economy and their impact on resource allocation:

- Income convergence gains depend critically on the share of EU funds funneled to productive public investment. Funds devoted to income support-a temporary demand shock - have limited and short-lived output effects, while those resulting in productive public investment - a long-lived supply shock - boost capital accumulation, productivity gains and eventually long run growth.

- Initially, as EU funds boost income, resources are shifted to the nontraded goods sector, whose demand increases as income rises. Over time, however, productive public investment increases domestic competitiveness, and thus gradually production shifts back to the tradable sector. Meanwhile, the real exchange rate depreciates, as the productivity gains give these countries a competitive edge on foreign markets, thereby alleviating the potential for Dutch disease effects.

Poland, would also benefit from taking advantage of the period of EU funds inflow to consolidate its fiscal position. Saving the fiscal revenue generated by the growth boost would entail a substantial decline in the public debt ratio over the medium run. Moreover, by gradually substituting other current spending with EU-financed public investment, the authorities could rebalance public expenditure from non-discretionary spending toward capital spending and thereby mitigate the negative macroeconomic impact of fiscal retrenchment.

1/ Selected Issues Paper by Celine Allard. 


\section{The more ambitious fiscal consolidation path will have numerous advantages.}

The authorities underscored the need to establish appropriate cyclical safety margins in terms of the Maastricht deficit, and create space for planned tax cuts and public investment within the context of the adjustment program. Staff noted the added benefit of relieving pressure on monetary policy by letting fiscal policy assume a greater share of the stabilization burden. This is particularly important considering that an over-reliance on monetary policy to deal with demand pressures could entice capital inflows, exacerbating upward pressures on the zloty. Staff also argued that a more ambitious path of fiscal consolidation would help safeguard external sustainability by dampening a medium-term current account deficit that is currently envisaged to approach the upper bound of what is sustainable.

22. There was agreement that Poland has room for allowing automatic stabilizers to work in a downturn. Should the downside risks to the baseline growth scenario materialize because of larger-then-anticipated negative external spillovers, the medium-term adjustment trajectory could be lengthened to facilitate greater fiscal support to activity. The still comfortable external current account deficit affords room for maneuver in this regard.

\section{The authorities recognized the need to strengthen the medium-term fiscal}

framework. Staff noted that the current framework lags best practice. In particular, its focus on annual budgets - with the medium-term targets agreed with the EU having little bearing on annual targets - lends a somewhat myopic slant to fiscal policy. To guard against a procyclical policy, staff suggested rolling three-year nominal expenditure ceilings that would not be adjusted as macroeconomic circumstances change. A three-year framework could possibly also broaden political support for medium term targets and spending priorities, and strengthen the efficiency of spending financed by EU funds, especially if lower levels of government were included. The authorities agreed that the annual focus was a weakness, but noted that fiscal policy is anchored by a constitutional limit on public debt and that strict procedures prevent revenue windfalls from being spent. They also felt that the advantage of a fully-fledged medium-term framework would be limited as long as non-discretionary expenditures remain very high. Overall, they welcomed staff's suggestions and expressed interest in further exploring options in this area.

\section{Limited FinANCIAL SECTOR VULNERABILITIES AND SUPERVISION}

24. Financial sector risks are limited. The authorities noted that the rapid expansion of credit has been associated with some reduction in capital adequacy ratios. However, they also noted that the banking system remained well capitalized and profitable, the overall share of foreign liabilities is small, and the current financial market turmoil has so far had scant impact on Polish markets. Stress tests suggest only limited systemic risks from major external shocks, with all but a small number of banks able to absorb losses fully from income. A potential vulnerability arises from the mismatch between longer-term foreign currency denominated-assets (mostly variable-rate mortgages) and shorter-term liabilities in the banking system. In this regard, since some of the major international banks that are 
affected by the turmoil are active in Poland, one concern is the risk that they could curtail lending to their Polish subsidiaries. The authorities noted, however, that there was no evidence of this so far and that the high profitability of the subsidiaries made it unlikely that the parent group would pull back. While a few banks that have relied heavily on external lending to expand credit could find difficult to rollover such liabilities, the authorities saw no broader systemic risk in this regard.

25. The recent consolidation of supervisory functions comes at a difficult time. The unification was completed on January 1, 2008 when the NBP's banking supervision department was merged into the Financial Supervision Authority (KNF). In discussing operational aspects of the new unified agency, discussions focused on two issues identified during the 2006 FSAP:

- $\quad$ Ensuring a smooth transfer of banking supervision from the NBP to the KNF. Responding to staff concerns, the authorities noted that the two bodies had signed an operational memorandum governing the exchange of information, and that existing processes and procedures, safety net arrangements, and human resources had been retained. Consequently, the ability to monitor and respond in a timely and comprehensive manner had not been impaired. They also noted that a confidential tripartite memorandum of understanding between the ministry of finance, the NBP and the KNF on financial stability had been signed - this memorandum included an agreement to update financial stability arrangements in line with EU-level commitments.

- $\quad$ Strengthening the autonomy and governance of the KNF. Staff argued that appointment and dismissal procedures for members of the KNF's board felt short of best practice by providing few safeguards against political interference. Introducing fixed terms of appointment would help ensure that board members, once appointed, remained independent and served only in their technical capacity. While acknowledging the issue in principle, the authorities felt that the autonomy of the KNF was unlikely to be undermined in practice and that this was not the time to address these governance concerns.

\section{ENHANCING GrowTH AND FleXibILITy, AND Euro AdOPTION}

26. Boosting the labor force holds the key to long-term growth prospects. The authorities recognized that Poland's exceptionally low labor participation-especially among those above 50 years of age-was a major obstacle to long-term growth (Figure 2), and that increasing labor supply meant reforming the generous provisions for early retirement, bettertargeting disability benefits, and further reducing the tax wedge, especially at lower levels of income. They had not yet formulated concrete plans, however. Staff also pointed to the need to reform the farmer's pension scheme (KRUS), with the ultimate goal of merging it into the general scheme. It noted that the experience of several EU member countries-including 
Ireland and the Netherlands - has shown that incremental reforms can have a significant long-term impact on labor participation, especially in the context of social partnership frameworks (Box 2).

27. Product market liberalization and privatization will be high on the agenda. The authorities recognized that Poland lags its peers in this area. They explained that the new government has given priority to cutting red tape and reinvigorating the stalled privatization program, stressing that they intend to take early action in this regard to secure catch-up gains in productivity. Staff welcomed this, noting that labor-supply enhancing policies tended to be more effective in the context of liberal product markets.

28. The authorities are committed to euro adoption as soon as circumstances permit. They recognized that Poland's preparedness to join and subsequently thrive in the EMU will hinge on curtailing the economy's susceptibility to country-specific shocks, and on furthering its adaptability to such shocks. They felt that both their focus on macroeconomic stability and their broad reform priorities meant that such preparedness was set to steadily improve. They stressed, however, the importance of ensuring that all the necessary conditions were met on a sustainable basis before establishing a rigid timetable for entering ERM2 (Figure 3). Staff supported the authorities' plans in this regard. 


\section{Box 2. What Can Poland Learn from Other EU Countries Regarding Labor Market Reforms? ${ }^{1 /}$}

Over the past quarter century, Ireland and the Netherlands have seen their unemployment rates fall more sharply, and their employment rates rise more steeply, than any other EU country. After an initial crisis, both countries propelled themselves to the top of the class in terms of labor market outcomes. They did this on the back of an internally consistent nexus of reforms that complemented and reinforced each other. Interestingly, Poland's situation today in terms of employment, unemployment, and participation is similar to that of Ireland in early 1980s, on the eve of its reform program.

The reform program in Ireland and the Netherlands focused on boosting labor supply. In both countries, this was attained by coordinated agreements between the social partners, where the effects of lower nominal wage growth were mitigated by labor tax cuts. Both countries had legacies of relatively liberal labor and product markets.

These results are supported by cross-country econometric evidence. Wage moderation tends to be affected by such factors as the tax wedge, benefits, the government wage bill, and degree of coordination or centralization in the wage-setting process. At the same time, low levels of product and labor market regulation allow this wage moderation to kindle vigorous private sector employment growth.

Poland could benefit significantly from a strategy of boosting labor supply in the context of a social partnership framework, especially in light of its high tax wedges and benefits, as well as its extensive product market regulation. As a simple thought experiment based on the panel econometric results, if Poland moved instantaneously to the position of Ireland for the key institutional variables - tax wedge, disability benefits, government wage bill, product market regulation, employment protection legislation, and wage bargaining coordination/ centralization - the private sector employment rate would climb by $9 \frac{1}{2} 2$ percentage points over three years, erasing 60 percent of the difference between the two countries in this variable. In terms of magnitude, product market regulation and the tax wedge are the most important variables contributing to the employment increase.

1/ Selected Issues Paper by Tony Annett.

\section{STAFF APPRAISAL}

29. Poland is enjoying strong and well-balanced economic growth with no serious domestic and external imbalances so far. Core inflation remains low, the external current account deficit is comfortable, and the zloty is within its estimated equilibrium range.

\section{But emerging supply constraints point to a dual challenge of limiting demand} pressures while tackling obstacles to long-term growth. Slower growth and rising core inflation suggest that the recovery is beginning to run up against supply-side constraints. 
Preventing cost pressures from impairing investment and competitiveness while boosting potential growth - not least through measures aimed at increasing the exceptionally low labor participation — should be the overarching objectives as the new coalition government formulates its economic program in the coming months.

31. External spillovers are unlikely to eliminate the need for policy tightening. There is no evidence of significant spillovers through financial channels at this stage. While exports are likely to slow, growth is set to remain at or above potential, with real wages still running well ahead of productivity. Thus, staff's baseline requires policy tightening. While the risk of a fundamentally different outlook - with below-potential growth calling for further policy tightening to be put on hold - can certainly not be dismissed, there is little evidence of this at this time.

32. The MPC should move quickly to bring inflation back to target, by maintaining a tightening bias in monetary policy. Staff is particularly concerned that inflationary expectations could get entrenched at elevated levels if a wage-price spiral takes hold, making it more costly - in terms of lower output growth - to bring inflation back to target. It is also concerned that expectations of a prolonged tightening bias could exert upward excessive pressure on the zloty. Thus, the uncertainty relating to the external outlook notwithstanding, it is too early to pause the tightening cycle.

33. In recommending further tightening, staff has taken into account that the banking system remains strong and that the turmoil in international capital markets poses no notably heightened systemic risks. Still, the unification of regulatory functions under the auspices of the KNF comes at a difficult time, and the authorities should give priority to ensuring that this does not impair timely and effective supervision. A particular concern in this regard is the need to ensure that current operational procedures remain in place and that existing staff are retained.

34. The new government's commitment to reducing the structural fiscal deficit to 1 percent of GDP over the medium-term is welcome. While it would have been desirable for the 2008 budget to advance this process, the relaxation is small and the new government admittedly had little time to approve a more appropriate budget. Looking beyond 2008, the more ambitious consolidation path will increase the scope for automatic stabilizers to work. In this regard, should external spillovers cause growth to drop below potential, there would be a case for delaying the consolidation and allow the counter-cyclical impulse from such stabilizers. The stronger consolidation will also provide an additional cushion against excessive external imbalances, which is important since the current account deficit is set to gradually increase to the upper bounds of what is sustainable from a long-term perspective.

35. Fiscal consolidation would need to focus on the expenditure side. While the new government is still in the process of formulating detailed plans, staff welcomes indications that lowering the deficit will take priority over cutting taxes. Priority should be given to 
streamlining socially sensitive benefit programs, considering the high level of nondiscretionary spending, and staff is encouraged by the support for this difficult task among senior officials. In this regard, strengthening the fiscal framework by introducing three-year rolling spending limits could not only provide a safeguard against pro-cyclical fiscal policy, but could also help mobilize broader and more durable political and social support for an expenditure-based consolidation program.

36. Increasing the exceptionally-low labor participation is key to long-term growth prospects. Reforming generous provisions for early retirement, reducing the tax wedge, and reforming the farmer's pension scheme should be a priority. In this area as well, staff is encouraged by the ideas and preliminary plans of senior officials, although it understands that changes will be socially sensitive. In this regard, the experience of other EU countries demonstrate that incremental progress in all of these areas could result in a significant increase in participation over the long run. The authorities should also be mindful that these measures will have highly complementary effects in that they will also facilitate fiscal consolidation.

37. Structural reforms could boost productivity. Higher labor utilization has accounted for most of the increase in output, with a relatively modest contribution from productivity gains. It should, therefore, be a priority to ensure that the waning scope for increasing labor utilization is offset by a gradual strengthening of productivity. In this regard, Poland is lagging its peers as far as the business climate is concerned, and there appears to be scope for realizing additional catch-up gains in productivity through further deregulation and privatization. The authorities' determination to restart the privatization program is therefore much welcomed.

38. Overall, the medium-term outlook is very favorable. The improvement in the investment climate that has followed EU accession, the prospect of increasing EU funds, the new government's commitment to reinvigorate reforms, and - not least - its determination to adopt the euro as soon as circumstances permit, all augur well for Poland's ability to take full advantage of its EU membership and ensure that income convergence continues apace.

39. It is recommended that the Article IV consultation remain on a 12-month cycle. 
Figure 1. Poland and Other Emerging European Countries: Private Credit, 2000-06
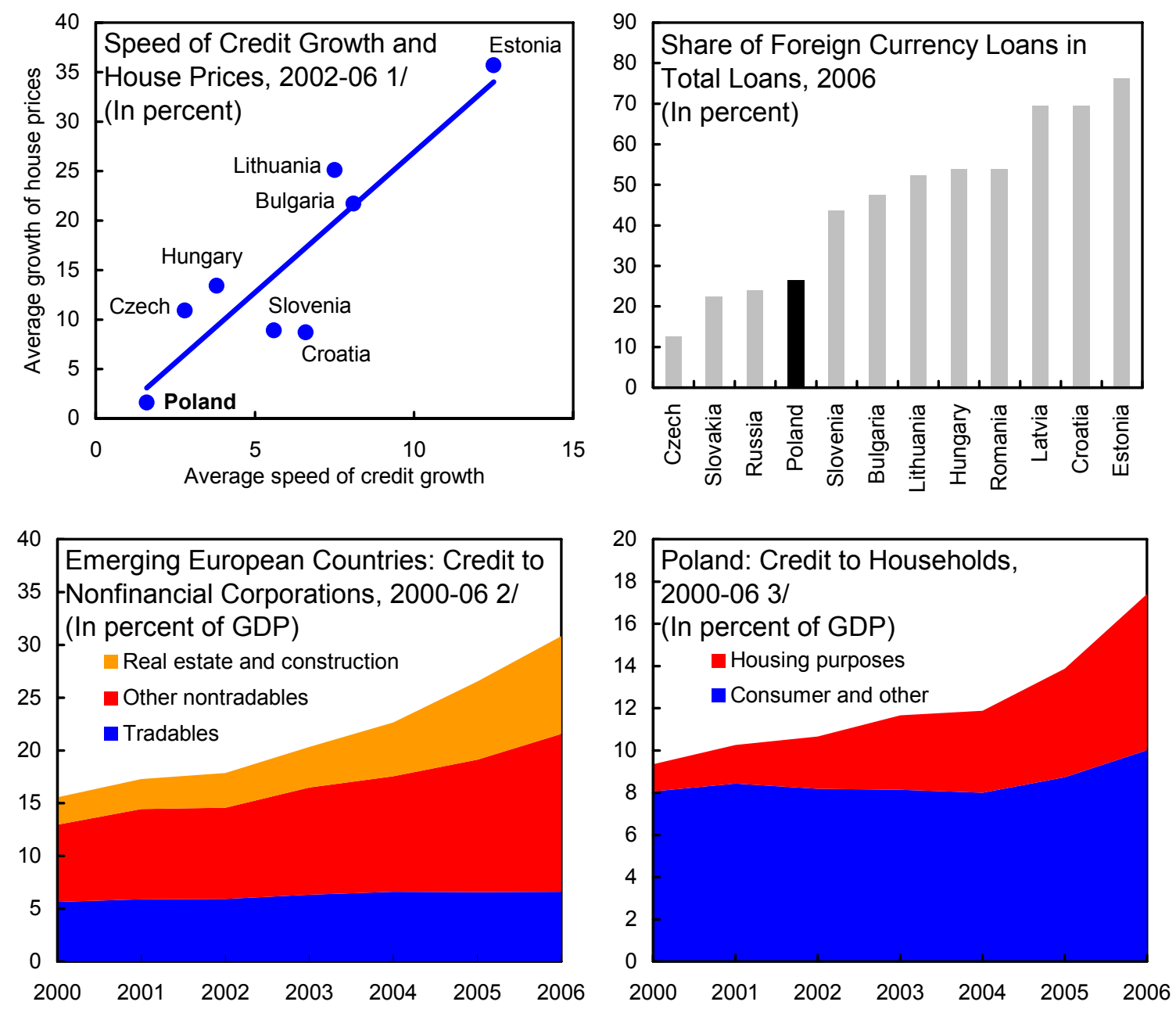

Source: Egert and Mihaljek (2007); European Central Bank; national authorities; and IMF staff calculations.

$1 /$ The speed of credit growth is defined as the annual percentage-point increase in the creditto-GDP ratio, averaged over the period 2002-2006. Credit measure includes direct crossborder credit and refers to households and nonfinancial corporations.

$2 /$ Credit measures exclude direct credit from abroad. The sample of countries consists of Bulgaria, Croatia, Czech (data not available in 2000), Estonia, Hungary, Latvia, and Lithuania. $3 /$ Credit measures exclude direct credit from abroad. The sample of countries consists of Bulgaria, Croatia, Czech, Estonia, Hungary, Latvia, and Poland. 
Figure 2. Poland and Other EU Countries: Labor Market Indicators, 1980-2006 1/
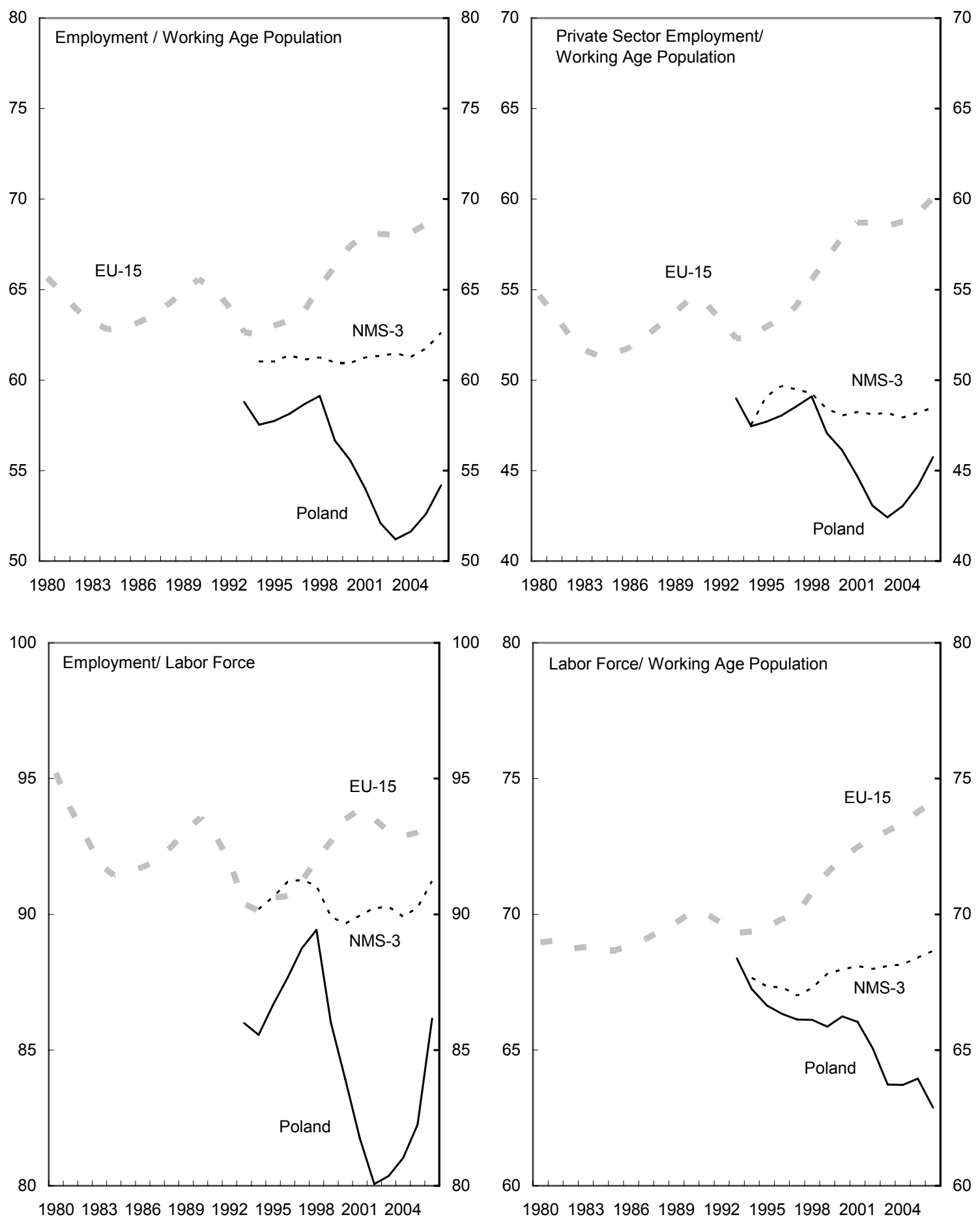

Source: OECD Economic Outlook and OECD Analytical Database.

1/ NMS-3 includes Czech Republic, Hungary, and Slovak Republic. 
Figure 3. Poland and Other CEE Countries: Real and Nominal Convergence with the Euro Area, 1995-2007
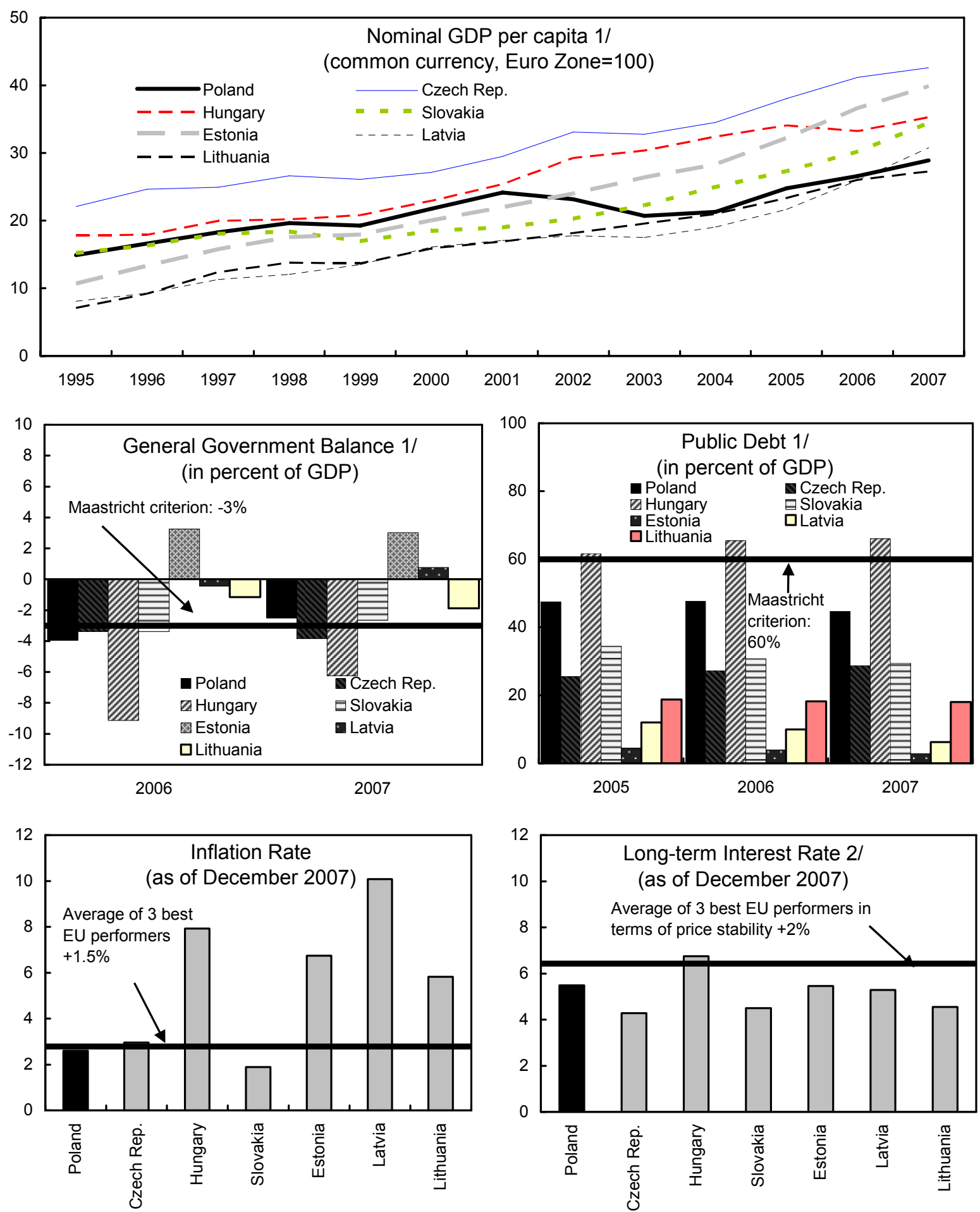

Sources: IMF, World Economic Outlook; and Eurostat.

1/ Projections for 2007.

2/ Estonia data is as of November 2007. 
Figure 4. Poland: External Debt Sustainability: Bound Tests 1/

(External debt in percent of GDP)
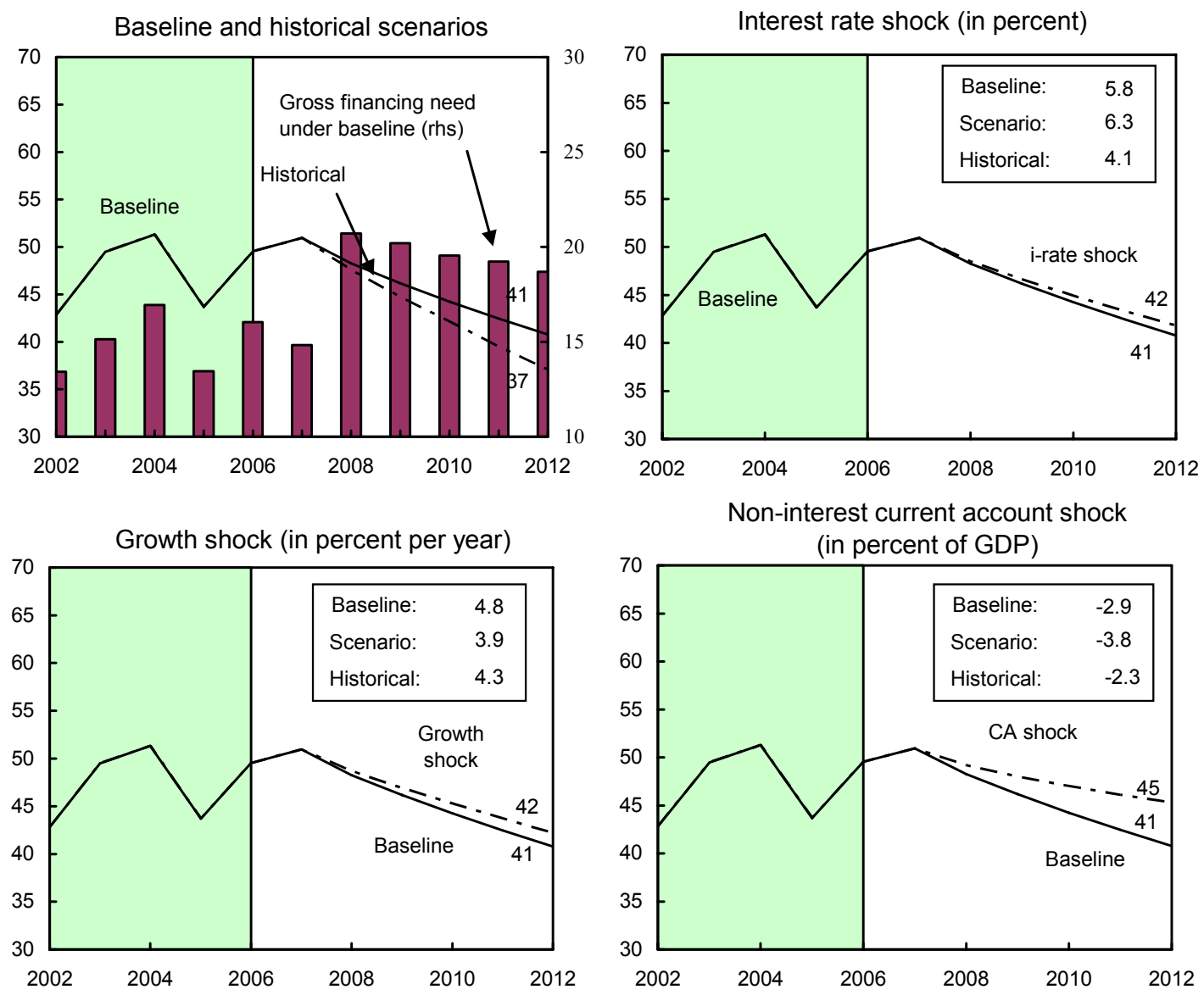

Combined shock 2/
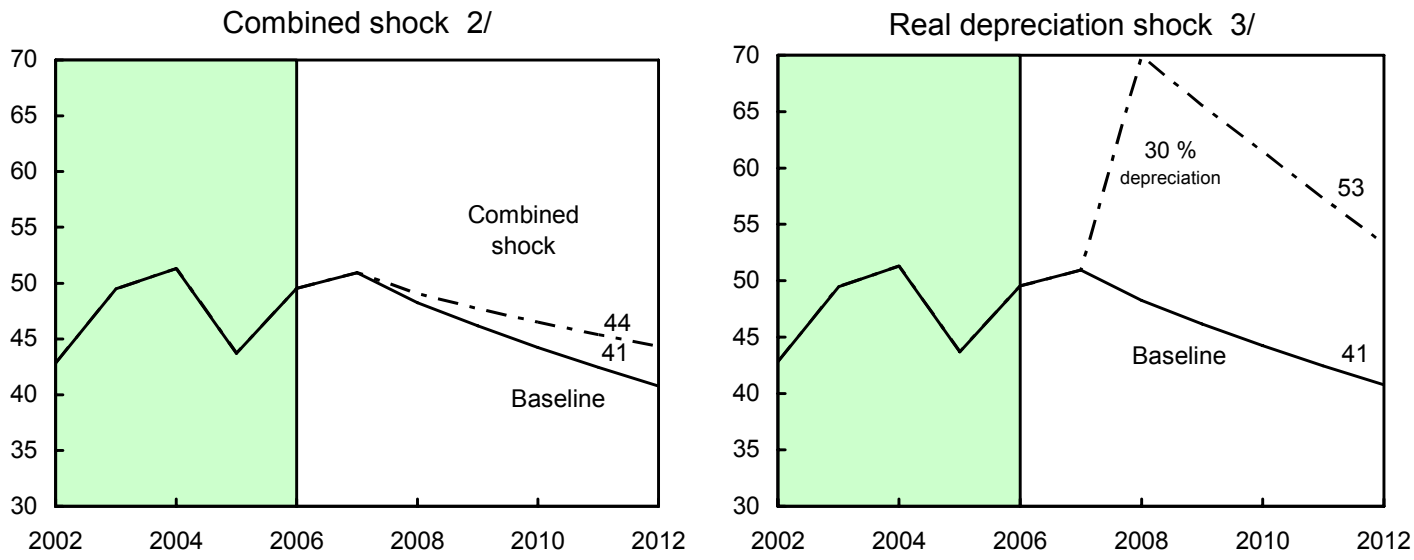

Sources: International Monetary Fund, Country desk data, and staff estimates.

$1 /$ Shaded areas represent actual data. Individual shocks are permanent one-half standard deviation shocks. Figures in the boxes represent average projections for the respective variables in the baseline and scenario being presented. Ten-year historical average for the variable is also shown.

2/ Permanent 1/4 standard deviation shocks applied to real interest rate, growth rate, and current account balance.

3/ One-time real depreciation of 30 percent occurs in 2008. 
Figure 5. Poland: Public Debt Sustainability: Bound Tests 1/

(Public debt in percent of GDP)
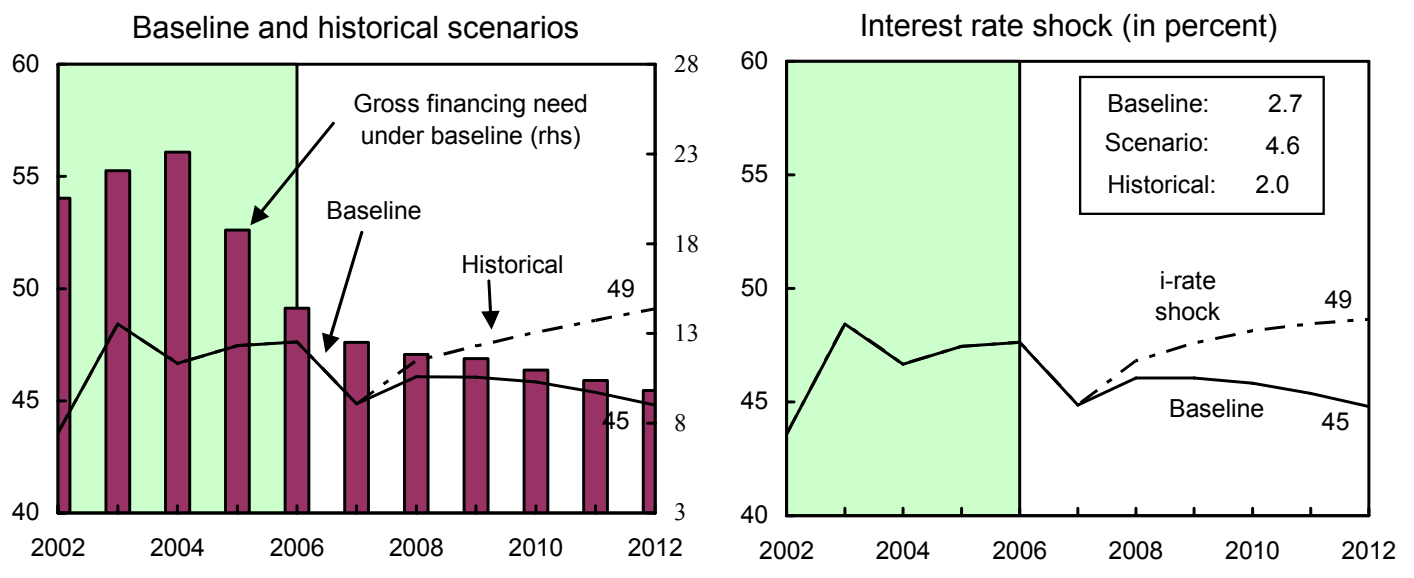

Primary balance shock (in percent of GDP) and

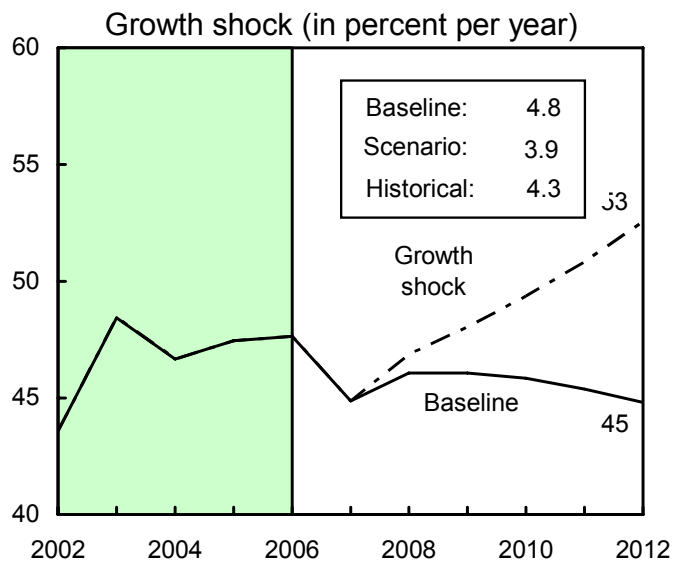
no policy change scenario (constant primary balance)

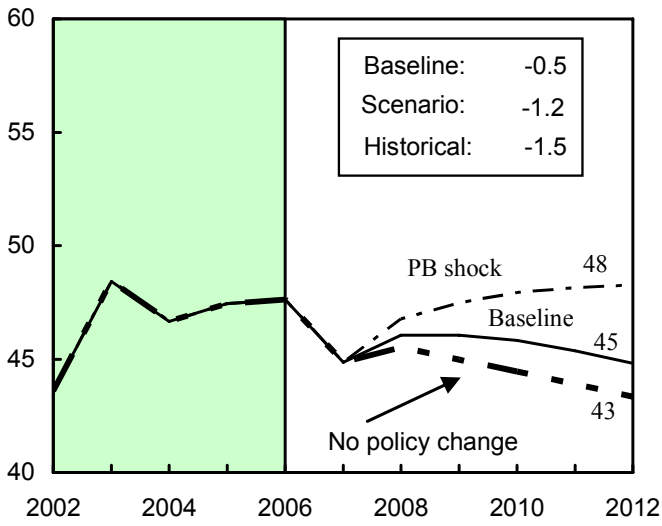

Combined shock 2/

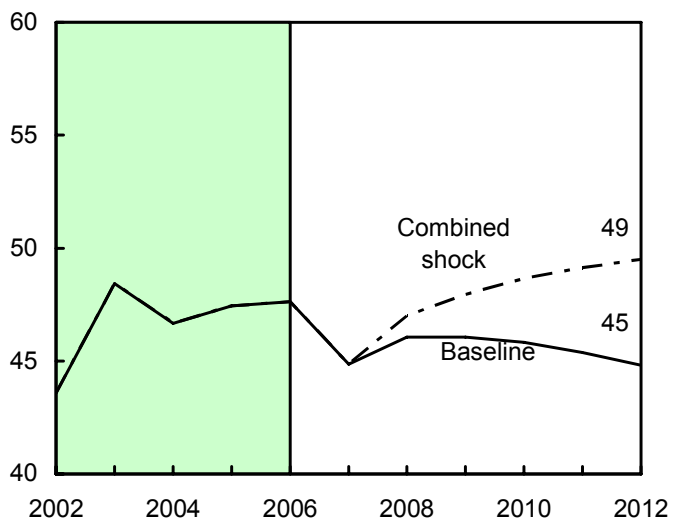

Real depreciation and contingent liabilities shocks 3/

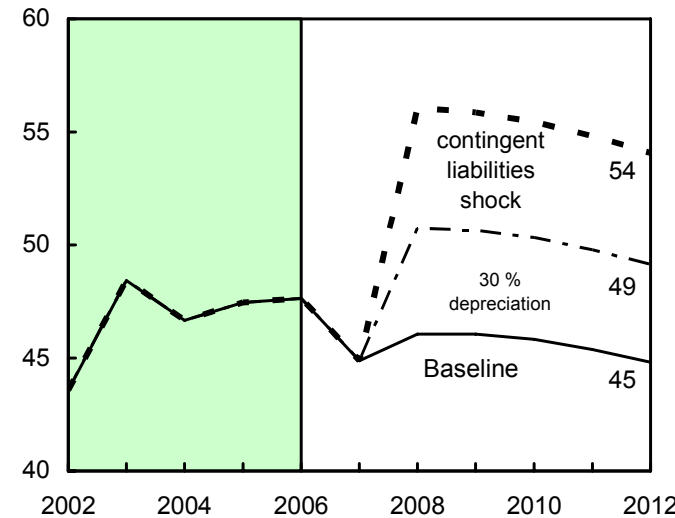

Sources: International Monetary Fund, country desk data, and staff estimates.

1/ Shaded areas represent actual data. Individual shocks are permanent one-half standard deviation shocks. Figures in the boxes represent average projections for the respective variables in the baseline and scenario being presented. Ten-year historical average for the variable is also shown.

2/ Permanent 1/4 standard deviation shocks applied to real interest rate, growth rate, and primary balance.

3 / One-time real depreciation of 30 percent and 10 percent of GDP shock to contingent liabilities occur in 2008, with real depreciation defined as nominal depreciation (measured by percentage fall in dollar value of local currency) minus domestic inflation (based on GDP deflator). 
Table 1. Poland: Selected Economic Indicators, 2002-09

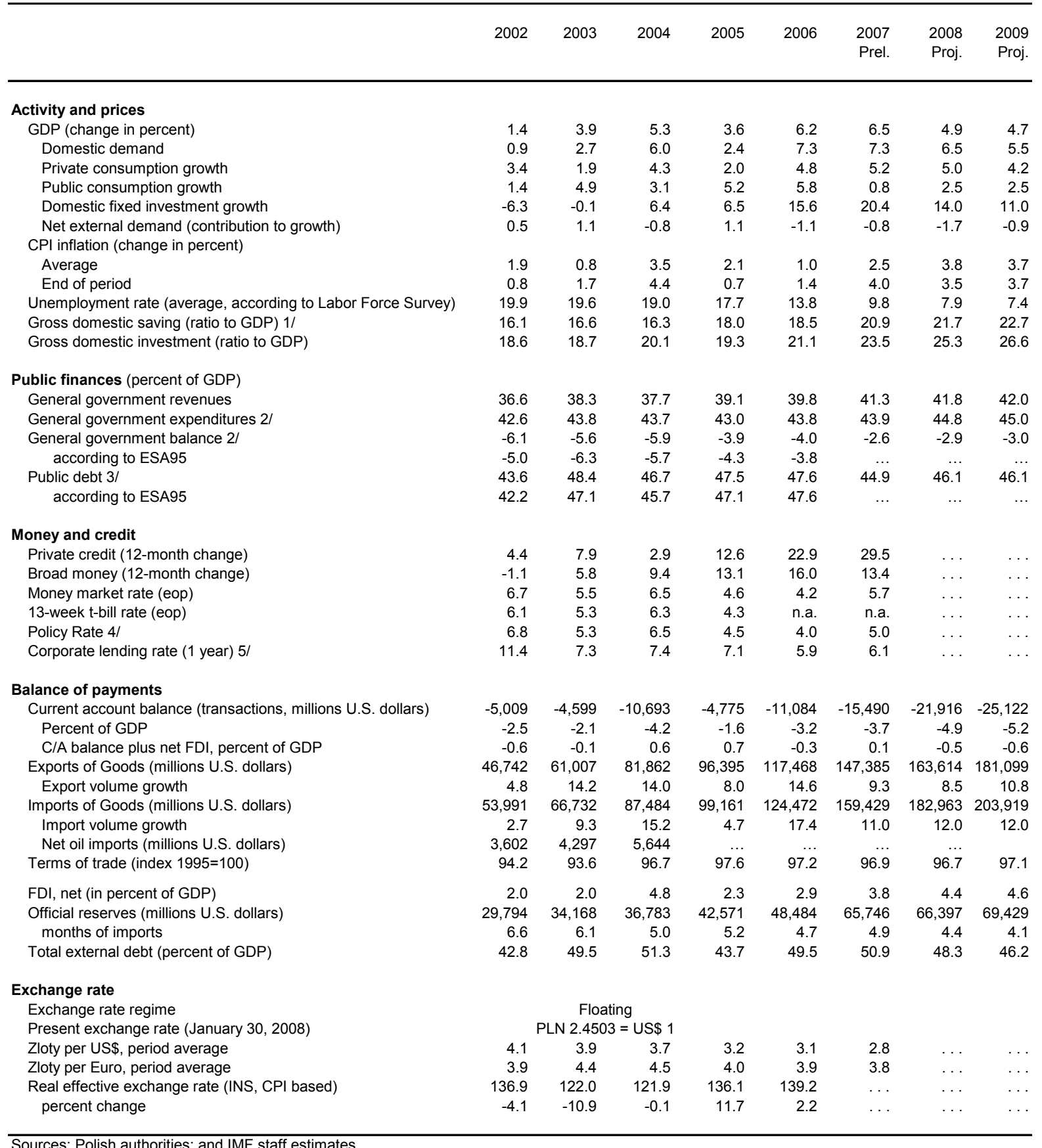

$1 /$ Derived as total savings minus the current account minus capital transfers.

2/ Fund definition (including the cost of the pension reform).

$3 /$ Polish definition of debt including risk weighted stock of outstanding guarantees.

4/ Yield on 7-day NBP money market bills.

5/ The methodology for computing interest rates was changed in 2004 to fulfil ECB requirements.

6/ The main reasons for the increase in international reserves since 2004 are an accumulation of EU transfers held in euros in the Ministry of Finance's account at the NBP, the appreciation of the euro against the dollar and, in 2007, a repo operation (\$5.3 billion) that will be reversed in 2008 . 
Table 2. Poland: Balance of Payments on Transaction Basis, 2004-13 (In millions of US\$)

\begin{tabular}{|c|c|c|c|c|c|c|c|c|c|c|}
\hline & 2004 & 2005 & $\begin{array}{r}2006 \\
\text { Est. }\end{array}$ & $\begin{array}{l}2007 \\
\text { Proj. }\end{array}$ & $\begin{array}{l}2008 \\
\text { Proj. }\end{array}$ & $\begin{array}{c}2009 \\
\text { Proj. }\end{array}$ & $\begin{array}{l}2010 \\
\text { Proj. }\end{array}$ & $\begin{array}{l}2011 \\
\text { Proj. }\end{array}$ & $\begin{array}{l}2012 \\
\text { Proj. }\end{array}$ & $\begin{array}{c}2013 \\
\text { Proj. }\end{array}$ \\
\hline Current account balance & $-10,693$ & $-4,775$ & $-11,084$ & $-15,490$ & $-21,916$ & $-25,122$ & $-27,214$ & $-31,215$ & $-34,004$ & $-37,190$ \\
\hline percent of GDP & -4.2 & -1.6 & -3.2 & -3.7 & -4.9 & -5.2 & -5.3 & -5.7 & -5.8 & -5.9 \\
\hline Trade balance & $-5,622$ & $-2,766$ & $-7,004$ & $-12,044$ & $-19,349$ & $-22,820$ & $-26,198$ & $-30,407$ & $-34,621$ & $-38,450$ \\
\hline percent of GDP & -2.2 & -0.9 & -2.0 & -2.9 & -4.3 & -4.8 & -5.1 & -5.5 & -5.9 & -6.1 \\
\hline \multicolumn{11}{|l|}{ Exports } \\
\hline percentage change in unit values & 32.1 & 18.2 & 22.5 & 19.2 & 11.0 & 10.7 & 10.8 & 11.0 & 11.8 & 12.0 \\
\hline percentage volume growth & 14.0 & 8.0 & 14.6 & 9.3 & 8.5 & 10.8 & 11.0 & 10.7 & 10.6 & 10.6 \\
\hline export market growth & 11.1 & 8.4 & 12.1 & 8.6 & 8.4 & 6.8 & 6.8 & 6.3 & 6.3 & 6.2 \\
\hline \multicolumn{11}{|l|}{ Imports } \\
\hline percentage change in unit values & 29.2 & 13.5 & 25.9 & 21.5 & 14.8 & 11.5 & 11.3 & 11.6 & 12.0 & 11.8 \\
\hline percentage volume growth & 15.2 & 4.7 & 17.4 & 11.0 & 12.0 & 12.0 & 11.7 & 11.4 & 11.1 & 11.1 \\
\hline growth in domestic demand & 6.0 & 2.4 & 7.3 & 7.3 & 6.5 & 5.5 & 5.3 & 5.4 & 5.3 & 5.3 \\
\hline Terms of trade percentage change & 3.3 & 0.9 & -0.3 & -0.4 & -0.1 & 0.4 & 0.3 & 0.1 & 0.3 & 0.5 \\
\hline Services balance & 1,014 & 1,946 & 2,217 & 4,883 & 4,864 & 5,179 & 5,610 & 6,035 & 6,653 & 7,493 \\
\hline Credit & 13,471 & 16,258 & 20,584 & 28,040 & 31,439 & 34,799 & 38,571 & 42,816 & 47,856 & 53,576 \\
\hline Debit & 12,457 & 14,312 & 18,367 & 23,157 & 26,575 & 29,619 & 32,962 & 36,782 & 41,204 & 46,084 \\
\hline Net Income & $-11,536$ & $-10,889$ & $-14,500$ & $-18,337$ & $-17,178$ & $-18,105$ & $-19,351$ & $-20,915$ & $-22,561$ & $-24,565$ \\
\hline Net transfers & 5,451 & 6,934 & 8,203 & 10,008 & 9,747 & 10,624 & 12,726 & 14,072 & 16,525 & 18,333 \\
\hline o/w EU receipts & 1,978 & 3,902 & 4,239 & 4,522 & 3,844 & 4,270 & 5,890 & 6,715 & 8,278 & 9,082 \\
\hline o/w payment to EU & $-1,635$ & $-3,031$ & $-3,178$ & $-3,629$ & $-3,906$ & $-4,203$ & $-4,523$ & $-4,867$ & $-5,239$ & $-5,646$ \\
\hline Capital and financial account balance & 9,712 & 16,290 & 14,216 & 34,840 & 22,567 & 28,154 & 33,217 & 37,193 & 43,431 & 48,809 \\
\hline Capital account balance & 1,180 & 995 & 2,105 & 4,774 & 5,657 & 6,288 & 8,708 & 9,936 & 12,270 & 13,465 \\
\hline o/w net EU transfers & & 1,012 & 2,290 & 4,659 & 5,767 & 6,406 & 8,835 & 10,072 & 12,416 & 13,623 \\
\hline Financial account balance & 8,532 & 15,295 & 12,111 & 30,066 & 16,910 & 21,866 & 24,509 & 27,257 & 31,162 & 35,344 \\
\hline Foreign direct investment (net) & 12,259 & 7,013 & 10,037 & 15,967 & 19,811 & 22,204 & 24,872 & 27,847 & 31,346 & 35,106 \\
\hline by nonresidents & 13,091 & 10,363 & 19,198 & 18,747 & 20,811 & 23,204 & 25,872 & 28,847 & 32,346 & 36,106 \\
\hline o/w privatization & 197 & 31 & 8 & 95 & 100 & 100 & 100 & 100 & 100 & 100 \\
\hline Portfolio investment (net) & 9,281 & 12,600 & $-3,007$ & $-6,133$ & -900 & -969 & $-1,042$ & $-1,321$ & -971 & -609 \\
\hline by non-residents & 10,612 & 15,109 & 1,543 & 332 & 2,300 & 2,475 & 2,664 & 2,867 & 3,085 & 3,325 \\
\hline o/w equities & 1,660 & 1,333 & $-2,134$ & -897 & 300 & 323 & 347 & 374 & 402 & 434 \\
\hline Other investment & $-13,208$ & $-4,511$ & 5,838 & 22,326 & $-2,001$ & 631 & 679 & 731 & 787 & 848 \\
\hline Assets & $-11,999$ & $-2,782$ & $-3,734$ & $-1,491$ & $-2,201$ & $-2,369$ & $-2,549$ & $-2,743$ & $-2,952$ & $-3,182$ \\
\hline Liabilities & $-1,209$ & $-1,729$ & 9,572 & 23,817 & 200 & 3,000 & 3,228 & 3,474 & 3,739 & 4,029 \\
\hline Financial derivatives & 200 & 193 & -757 & $-2,094$ & 0 & 0 & 0 & 0 & 0 & 0 \\
\hline Errors and omissions & 1,771 & $-3,380$ & -652 & $-6,472$ & 0 & 0 & 0 & 0 & 0 & 0 \\
\hline Overall balance & 790 & 8,135 & 2,480 & 12,878 & 651 & 3,032 & 6,003 & 5,978 & 9,428 & 11,619 \\
\hline \multicolumn{11}{|l|}{ Financing } \\
\hline Reserve assets & -790 & $-8,135$ & $-2,480$ & $-12,878$ & -651 & $-3,032$ & $-6,003$ & $-5,978$ & $-9,428$ & $-11,619$ \\
\hline \multicolumn{11}{|l|}{ Memorandum items: } \\
\hline Current plus capital account (percent of GDP) & -3.8 & -1.2 & -2.6 & -2.6 & -3.6 & -3.9 & -3.6 & -3.9 & -3.7 & -3.8 \\
\hline Official reserves $1 /$ & 36,783 & 42,571 & 48,484 & 65,746 & 66,397 & 69,429 & 75,432 & 81,410 & 90,838 & 102,457 \\
\hline in months of imports & 5.0 & 5.2 & 4.7 & 4.9 & 4.4 & 4.1 & 4.0 & 3.9 & 3.8 & 3.9 \\
\hline Ratio of reserves to short-term debt $2 /$ & 106.3 & 101.8 & 97.4 & 103.7 & 92.8 & 92.6 & 95.2 & 101.6 & 107.6 & 117.7 \\
\hline Total external debt (percent of GDP) & 51.3 & 43.7 & 49.5 & 50.9 & 48.3 & 46.2 & 44.2 & 42.5 & 40.8 & 39.2 \\
\hline Total external debt (percent of exports) $3 /$ & 136.2 & 117.9 & 122.6 & 121.9 & 110.8 & 102.5 & 94.8 & 87.6 & 80.6 & 74.0 \\
\hline External debt service (percent of exports) $3 / 4 /$ & 27 & 22 & 26 & 20 & 23 & 21 & 20 & 19 & 18 & 17 \\
\hline Gross FDI inflows (percent of GDP) & 5.2 & 3.4 & 5.6 & 4.5 & 4.6 & 4.8 & 5.0 & 5.3 & 5.5 & 5.7 \\
\hline Net FDI inflows (percent of GDP) & 4.8 & 2.3 & 2.9 & 3.8 & 4.4 & 4.6 & 4.9 & 5.1 & 5.3 & 5.6 \\
\hline
\end{tabular}

Sources: National Bank of Poland; and IMF staff estimates.

1/ The main reasons for the increase in international reserves since 2004 are an accumulation of EU transfers held in euros in the Ministry of Finance's account at the NBP, the appreciation of the euro against the dollar and, in 2007, a repo operation ( $\$ 5.3$ billion) that will be reversed in 2008.

2/ By remaining maturity.

3/ Exports of goods and services.

4/ Excluding repurchase of debt. 
Table 3. Underlying Current Account in 2007 1/

\begin{tabular}{lcc}
\hline & \multicolumn{2}{c}{ Estimates using } \\
\cline { 2 - 3 } & $\begin{array}{c}\text { Transtition economies' } \\
\text { elastiticities }\end{array}$ & $\begin{array}{c}\text { Poland-specific } \\
\text { elasticitites }\end{array}$ \\
\hline Underlying current account balance (CAB) & & -4.5 \\
assuming a foreign output gap equal to: & -5.1 & -4.9 \\
$\quad-0.5$ percent & -5.5 & -5.2 \\
$\quad 0.0$ percent & -5.8 & \\
$\quad$ 0.5 percent & & -3.7 \\
Memo items: & & -6.0 \\
CAB & & \\
External-debt stabilizing (non-interest) CAB & & \\
\hline Source: WEO, IMF; Staff calculations. \\
1/ Calculations are based on the formula proposed in "A Calibrated Model of the Underlying Current Account," by \\
Messrs. Bayoumi and Faruqee (Chapter 5, in Occasional Paper 167, IMF); transition economies' elasticities are taken \\
from that paper.
\end{tabular}




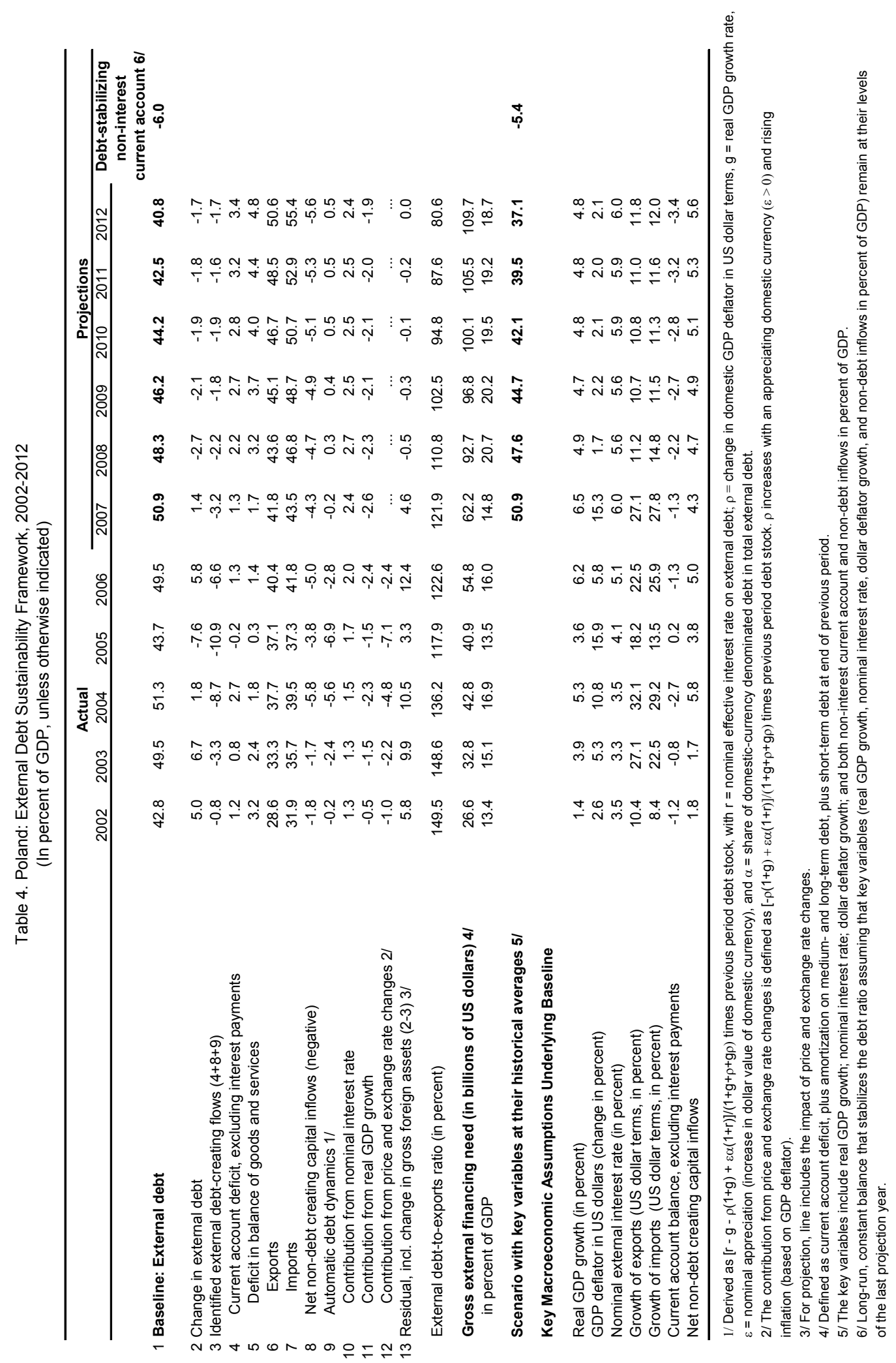


Table 5. Poland: General Government Revenues and Expenditures, 2002-09 (In percent of GDP)

\begin{tabular}{|c|c|c|c|c|c|c|c|c|}
\hline & 2002 & 2003 & 2004 & 2005 & 2006 & $\begin{array}{r}2007 \\
\text { Est. }\end{array}$ & $\begin{array}{l}2008 \\
\text { Proj. }\end{array}$ & $\begin{array}{l}2009 \\
\text { Proj. }\end{array}$ \\
\hline General government revenue & 36.6 & 38.3 & 37.7 & 39.1 & 39.8 & 41.3 & 41.8 & 42.0 \\
\hline Taxes & 19.1 & 19.2 & 18.5 & 19.8 & 21.2 & 22.3 & 22.8 & 22.8 \\
\hline Social security contributions & 10.9 & 11.0 & 11.8 & 12.0 & 12.0 & 12.2 & 10.7 & 10.7 \\
\hline Other taxes and nontax & 6.5 & 8.0 & 7.3 & 7.3 & 6.7 & 6.8 & 8.3 & 8.5 \\
\hline General government expenditure 1/ & 42.6 & 43.8 & 43.7 & 43.0 & 43.8 & 43.9 & 44.8 & 45.0 \\
\hline Goods and services & 14.3 & 15.4 & 15.3 & 17.6 & 17.7 & 21.0 & 21.6 & 21.6 \\
\hline Transfers and subsidies & 22.6 & 22.9 & 22.8 & 19.8 & 20.1 & 18.4 & 18.1 & 17.9 \\
\hline Interest payments & 3.0 & 2.9 & 2.4 & 2.5 & 2.6 & 2.4 & 2.2 & 2.3 \\
\hline Capital and net lending & 2.7 & 2.7 & 3.2 & 3.1 & 3.3 & 2.1 & 2.9 & 3.2 \\
\hline General government balance 1/ & -6.1 & -5.6 & -5.9 & -3.9 & -4.0 & -2.6 & -2.9 & -3.0 \\
\hline Financing & 6.1 & 5.6 & 5.9 & 3.9 & 4.0 & 2.6 & 2.9 & 3.0 \\
\hline Domestic & 5.3 & 4.4 & 4.5 & 2.3 & 3.2 & 1.9 & 2.2 & 2.4 \\
\hline External & 0.5 & 0.8 & 0.3 & 1.2 & 0.7 & 0.6 & 0.6 & 0.5 \\
\hline Privatization & 0.2 & 0.4 & 1.1 & 0.3 & 0.0 & 0.1 & 0.2 & 0.1 \\
\hline \multicolumn{9}{|l|}{ Memorandum items: } \\
\hline Structural balance 2/ & -4.9 & -4.2 & -4.9 & -2.6 & -3.2 & -2.4 & -2.8 & -2.9 \\
\hline Underlying balance $3 /$ & -4.3 & -3.9 & -4.4 & -3.1 & -3.0 & -2.3 & -2.5 & -2.6 \\
\hline Primary balance & -3.1 & -2.7 & -3.5 & -1.3 & -1.3 & -0.2 & -0.7 & -0.7 \\
\hline $\begin{array}{l}\text { ESA95 deficit } \\
\text { of which: }\end{array}$ & -5.0 & -6.3 & -5.7 & -4.3 & -3.8 & $\ldots$ & $\ldots$ & $\ldots$ \\
\hline State balance (excluding pension reform costs) & -4.9 & -4.4 & -5.7 & -4.2 & -3.8 & -2.8 & -3.5 & -3.4 \\
\hline Rest of government balance & -1.2 & -1.2 & -0.2 & 0.3 & -0.1 & 0.2 & 0.6 & 0.4 \\
\hline Public debt $4 /$ & 43.6 & 48.4 & 46.7 & 47.5 & 47.6 & 44.9 & 46.1 & 46.1 \\
\hline ESA95 public debt & 42.2 & 47.1 & 45.7 & 47.1 & 47.6 & $\ldots$ & $\ldots$ & $\ldots$ \\
\hline
\end{tabular}

Sources: Polish authorities; and IMF staff estimates and projections.

1/ Fund definition (including the cost of the pension reform).

2/ Actual balance corrected for economic cycle.

3/ Actual balance corrected for economic cycle and one-off/special effects.

4/ Polish definition of debt including risk weighted stock of outstanding guarantees. 


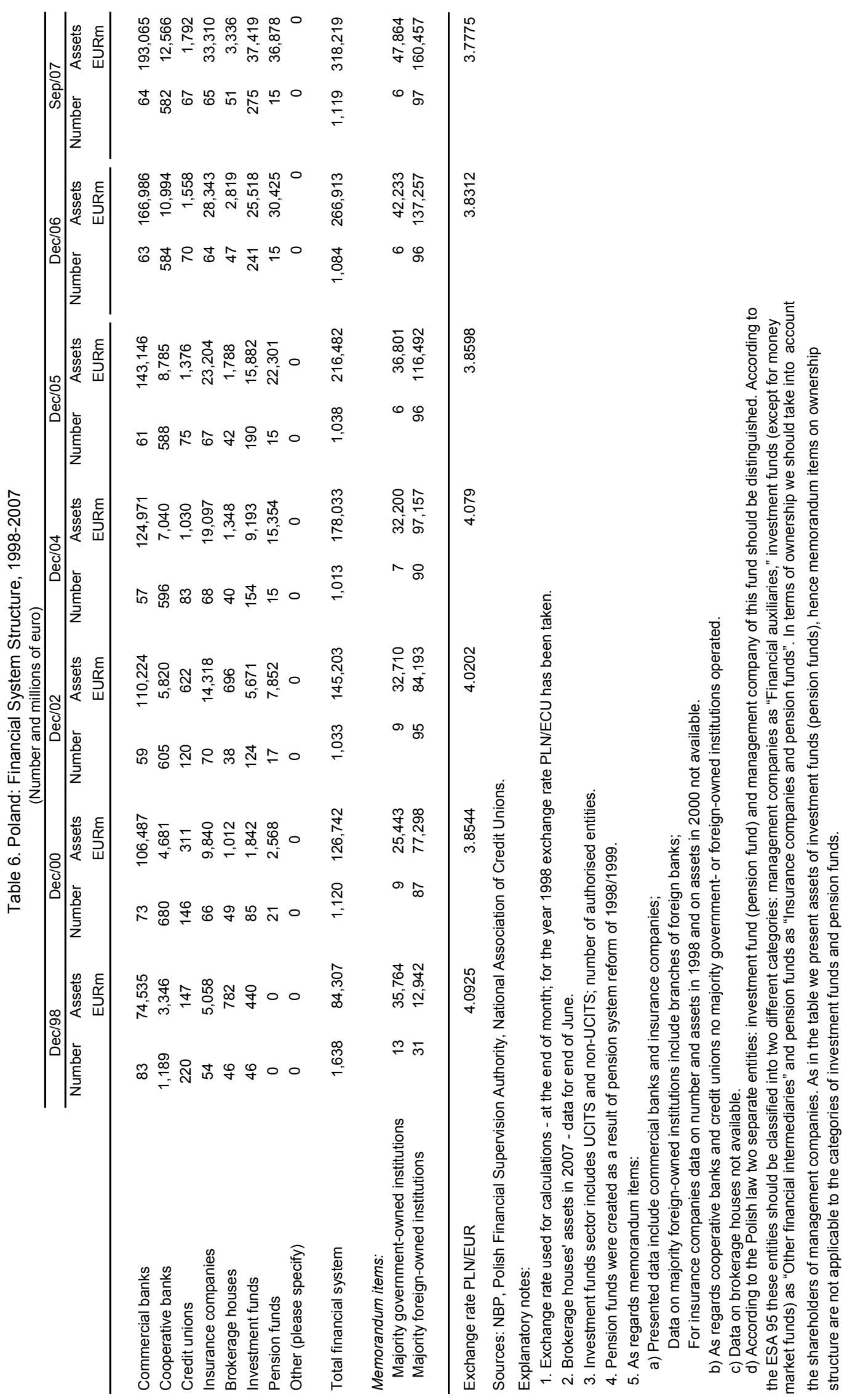




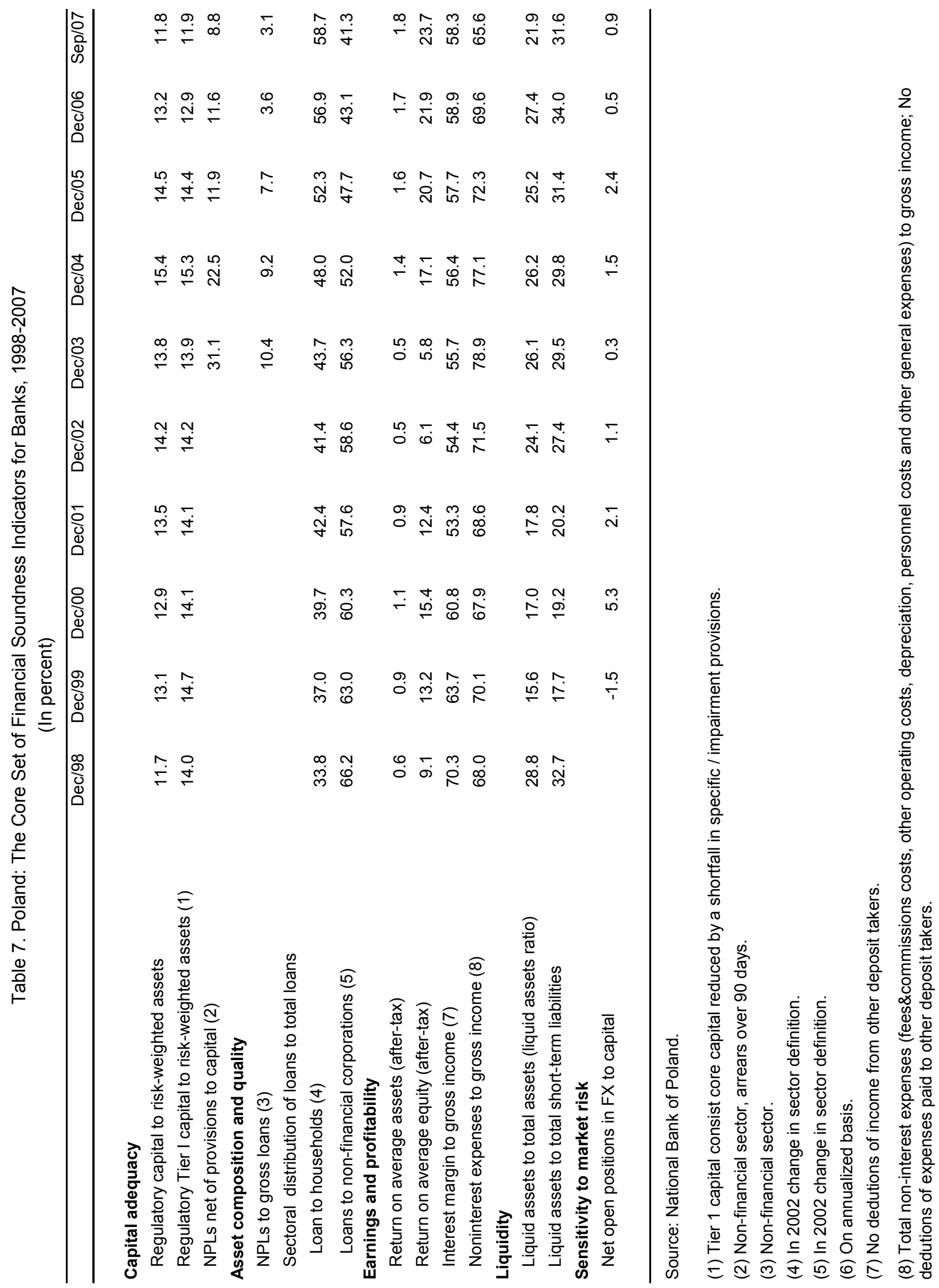


Table 8. Poland: Encouraged and Other Financial Soundness Indicators, 1998-2007

(In percent, unless otherwise indicated)

\begin{tabular}{|c|c|c|c|c|c|c|c|c|c|c|}
\hline & Dec/98 & Dec/99 & $\mathrm{Dec} / 00$ & $\mathrm{Dec} / 01$ & $\mathrm{Dec} / 02$ & $\mathrm{Dec} / 03$ & $\mathrm{Dec} / 04$ & Dec/05 & $\mathrm{Dec} / 06$ & Sep/07 \\
\hline \multicolumn{11}{|l|}{ Deposit-taking institutions } \\
\hline Capital to assets & 7.0 & 7.1 & 7.2 & 8.0 & 8.7 & 8.3 & 8.0 & 7.8 & 7.6 & 7.4 \\
\hline Large exposures to capital & & & & & & 404.5 & 379.0 & 370.3 & 387.9 & 415.7 \\
\hline Geographical distribution of loans to total loans & \multicolumn{10}{|c|}{ n.a. } \\
\hline \multicolumn{11}{|l|}{ Domestic } \\
\hline \multicolumn{11}{|l|}{ Foreign } \\
\hline Gross asset position in fin. derivatives to capital & & & & & & & & 27.8 & 25.0 & 28.4 \\
\hline Gross liability position in fin. derivatives to capital & & & & & & & & 25.8 & 23.0 & 27.1 \\
\hline Trading income to total income (1) & 10.1 & 12.0 & 16.9 & 23.3 & 21.4 & 14.6 & 14.2 & 14.8 & 11.9 & 12.6 \\
\hline Personnel expenses to noninterest expenses (2) & 48.4 & 46.7 & 44.2 & 43.7 & 42.2 & 41.4 & 40.1 & 42.9 & 44.8 & 44.8 \\
\hline Spread between reference loan and deposit rates (3) & 750.7 & 696.8 & 684.7 & 782.2 & 751.5 & 607.2 & 638.8 & 428.4 & 427.4 & 473.2 \\
\hline \multicolumn{11}{|l|}{ Spread between highest and lowest interbank rate (4) } \\
\hline $\mathrm{O} / \mathrm{N}$ & & & & 1.314 & 0.762 & 0.314 & 0.259 & 0.258 & 0.194 & 0.179 \\
\hline $\mathrm{T} / \mathrm{N}$ & 0.639 & 0.760 & 1.231 & 1.215 & 0.735 & 0.276 & 0.256 & 0.251 & 0.184 & 0.173 \\
\hline $1 \mathrm{~W}$ & 0.756 & 0.655 & 0.645 & 0.769 & 0.615 & 0.209 & 0.194 & 0.194 & 0.161 & 0.162 \\
\hline Customer deposits to total (non-interbank) loans & 151.6 & 140.8 & 140.0 & 148.1 & 141.8 & 136.4 & 137.2 & 135.8 & 117.0 & 96.8 \\
\hline FX denominated loans to total loans & 24.6 & 25.6 & 29.7 & 34.5 & 32.8 & 33.6 & 31.5 & 33.0 & 32.4 & 27.9 \\
\hline FX denominated liabilities to total liabilities & 20.7 & 22.2 & 19.7 & 20.8 & 20.3 & 21.5 & 19.2 & 19.2 & 16.9 & 17.1 \\
\hline Net open position in equities to capital & 4.9 & 5.8 & 5.7 & 4.2 & 4.2 & 4.4 & 2.5 & 1.6 & 2.9 & 2.6 \\
\hline \multicolumn{11}{|l|}{ Insurance sector } \\
\hline Solvency ratio (5) & 15.1 & 25.9 & 35.6 & 42.1 & 50.7 & 54.3 & 56.1 & 68.6 & 66.5 & 94.0 \\
\hline Life & 22.6 & 25.7 & 30.8 & 36.7 & 45.3 & 48.5 & 52.7 & 49.1 & 39.8 & 55.7 \\
\hline Non-life & 9.8 & 26.0 & 39.8 & 46.8 & 55.6 & 60.0 & 59.4 & 90.9 & 105.3 & 151.7 \\
\hline Return on average equity & 16.8 & 12.2 & 9.2 & 13.7 & 14.9 & 16.7 & 18.6 & 25.8 & 27.5 & 17.1 \\
\hline Life & 20.4 & 10.0 & 10.4 & 11.0 & 13.8 & 21.8 & 23.1 & 31.3 & 35.2 & 31.0 \\
\hline Non-life & 10.9 & 14.5 & 8.3 & 15.6 & 15.7 & 12.9 & 15.6 & 22.8 & 23.5 & 10.1 \\
\hline \multicolumn{11}{|l|}{ Nonfinancial corporations sector } \\
\hline Total debt to equity (6) & & & & & 109.1 & 105.9 & 87.8 & 80.7 & 81.2 & \\
\hline Total debt to corporate GDP & & & & & 63.5 & 65.3 & 57.2 & 55.4 & 57.0 & \\
\hline Return on equity & & & & & -0.8 & 5.2 & 12.0 & 9.5 & 10.9 & \\
\hline Earnings to interest and principal expenses & \multicolumn{10}{|c|}{ n.a. } \\
\hline \multicolumn{11}{|l|}{ Corporate net foreign exchange exposure to equity } \\
\hline Number of applications for protection from creditors & & & & & & & 227 & 156 & 96 & 70 \\
\hline \multicolumn{11}{|l|}{ Households } \\
\hline Household debt to GDP & 6.7 & 8.4 & 9.5 & 10.4 & 10.8 & 11.7 & 12.1 & 14.4 & 17.8 & 21.6 \\
\hline Household bank debt to disposable income & n.a. & 11.4 & 13.1 & 13.9 & 14.7 & 16.4 & 17.4 & 20.5 & 26.3 & 30.4 \\
\hline Household financial liabilities to disposable income & n.a. & 11.7 & 13.3 & 14.1 & 14.8 & 16.6 & 17.8 & 21.3 & 27.1 & 31.3 \\
\hline Household financial liabilities to financial assets (7) & n.a. & & 25.4 & 25.5 & 26.0 & 27.8 & 30.1 & 33.4 & 36.3 & 42.5 \\
\hline Household debt service and principal payments to income & \multicolumn{10}{|c|}{ n.a. } \\
\hline \multicolumn{11}{|l|}{ Market liquidity } \\
\hline Average bid-ask spread in the securities market (8) & & & 0.139 & 0.085 & 0.042 & 0.038 & 0.048 & 0.041 & 0.060 & 0.027 \\
\hline Average daily turnover ratio in the securities market (9) & & & 1.48 & 3.38 & 7.70 & 13.97 & 13.80 & 29.62 & 45.45 & 50.48 \\
\hline \multicolumn{11}{|l|}{ Real estate markets } \\
\hline \multicolumn{11}{|l|}{ Real estate prices } \\
\hline \multicolumn{11}{|l|}{ Commercial } \\
\hline Residential & \multicolumn{10}{|c|}{ n.a. } \\
\hline Residential real estate loans to total loans & 7.0 & 7.4 & 8.6 & 10.7 & 13.5 & 17.7 & 19.3 & 23.0 & 20.7 & 19.0 \\
\hline Commercial real estate loans to total loans & & & & & 1.2 & 2.0 & 3.5 & 3.6 & 3.8 & 3.7 \\
\hline
\end{tabular}

Source: NBP, Polish Financial Supervision Authority, Central Statistical Office.

(1) Net trading and FX income to total income.

(2) Personnel expenses to net noninterest income.

(3) Spread in weighted average loan and deposit rates for non-financial corporations and households. In 2002 change in sectors definition (1998 data cover November

and December only). In 2005 a change of methodology (data without current deposits and loans).

(4) Average bid/ask spread of the interbank interest rates.

(5) Available solvency margin / written premiums - net of reinsurance.

(6) Short and long term liabilities/equity.

(7) Financial assets - including shares.

(8) 5 Y Treasury bond average daily spreads.

(9) Billion zloty. Average gross daily turnover in the T-bonds market (assuming 252 working days per year, 2007 - 189 working days).

Data include 2 legs of Repo transactions. 
Table 9. Poland: Medium-Term Scenario, 2005-13

\begin{tabular}{|c|c|c|c|c|c|c|c|c|c|}
\hline & 2005 & $\begin{array}{r}2006 \\
\text { Est. }\end{array}$ & $\begin{array}{c}2007 \\
\text { Proj. }\end{array}$ & $\begin{array}{c}2008 \\
\text { Proj. }\end{array}$ & $\begin{array}{l}2009 \\
\text { Proj. }\end{array}$ & $\begin{array}{l}2010 \\
\text { Proj. }\end{array}$ & $\begin{array}{c}2011 \\
\text { Proj. }\end{array}$ & $\begin{array}{l}2012 \\
\text { Proj. }\end{array}$ & $\begin{array}{c}2013 \\
\text { Proj. }\end{array}$ \\
\hline \multicolumn{10}{|l|}{ Activity and prices } \\
\hline GDP (change in percent) & 3.6 & 6.2 & 6.5 & 4.9 & 4.7 & 4.8 & 4.8 & 4.8 & 4.8 \\
\hline Domestic demand growth & 2.4 & 7.3 & 7.3 & 6.5 & 5.5 & 5.3 & 5.4 & 5.3 & 5.3 \\
\hline Private consumption growth & 2.0 & 4.8 & 5.2 & 5.0 & 4.2 & 3.8 & 3.8 & 3.7 & 3.7 \\
\hline Public consumption growth & 5.2 & 5.8 & 0.8 & 2.5 & 2.5 & 2.5 & 2.5 & 2.5 & 2.5 \\
\hline Domestic fixed investment growth & 6.5 & 15.6 & 20.4 & 14.0 & 11.0 & 11.0 & 11.0 & 10.5 & 10.0 \\
\hline Net external demand (contribution to growth) & 1.1 & -1.1 & -0.8 & -1.7 & -0.9 & -0.8 & -0.8 & -0.8 & -0.8 \\
\hline $\mathrm{CPI}$ inflation (average change in percent) & 2.1 & 1.0 & 2.5 & 3.8 & 3.7 & 3.4 & 2.8 & 2.5 & 2.5 \\
\hline Unemployment rate & 18.2 & 16.2 & 12.7 & 10.8 & 10.4 & 10.4 & 10.4 & 10.4 & 10.4 \\
\hline Gross domestic saving (ratio to GDP) $1 /$ & 18.0 & 18.5 & 20.9 & 21.7 & 22.7 & 24.4 & 25.7 & 27.3 & 28.5 \\
\hline Private savings & 18.8 & 19.1 & 21.4 & 21.7 & 22.5 & 24.5 & 25.9 & 27.5 & 28.9 \\
\hline Public savings & -0.8 & -0.6 & -0.5 & 0.0 & 0.2 & 0.0 & -0.2 & -0.3 & -0.4 \\
\hline Gross domestic investment (ratio to GDP) & 19.3 & 21.1 & 23.5 & 25.3 & 26.6 & 28.0 & 29.5 & 31.0 & 32.3 \\
\hline \multicolumn{10}{|l|}{ Public finances (percent of GDP) } \\
\hline General government revenues & 39.1 & 39.8 & 41.3 & 41.8 & 42.0 & 42.0 & 42.0 & 42.1 & 42.1 \\
\hline General government expenditures & 43.0 & 43.8 & 43.9 & 44.8 & 45.0 & 44.9 & 44.7 & 44.7 & 44.6 \\
\hline General government balance 2/ & -3.9 & -4.0 & -2.6 & -2.9 & -3.0 & -2.8 & -2.7 & -2.5 & -2.5 \\
\hline Public debt $3 /$ & 47.5 & 47.6 & 44.9 & 46.1 & 46.1 & 45.8 & 45.4 & 44.8 & 44.2 \\
\hline \multicolumn{10}{|l|}{ Balance of payments (percent of GDP) } \\
\hline Current account balance & -1.6 & -3.2 & -3.7 & -4.9 & -5.2 & -5.3 & -5.7 & -5.8 & -5.9 \\
\hline Total external debt & 43.7 & 49.5 & 50.9 & 48.3 & 46.2 & 44.2 & 42.5 & 40.8 & 39.2 \\
\hline
\end{tabular}

Sources: Polish authorities; and IMF staff estimates.

1/ Derived as total savings minus the current account minus capital transfers.

2/ Fund definition (including the cost of the pension reform).

3/ Polish definition of debt including risk weighted stock of outstanding guarantees. 


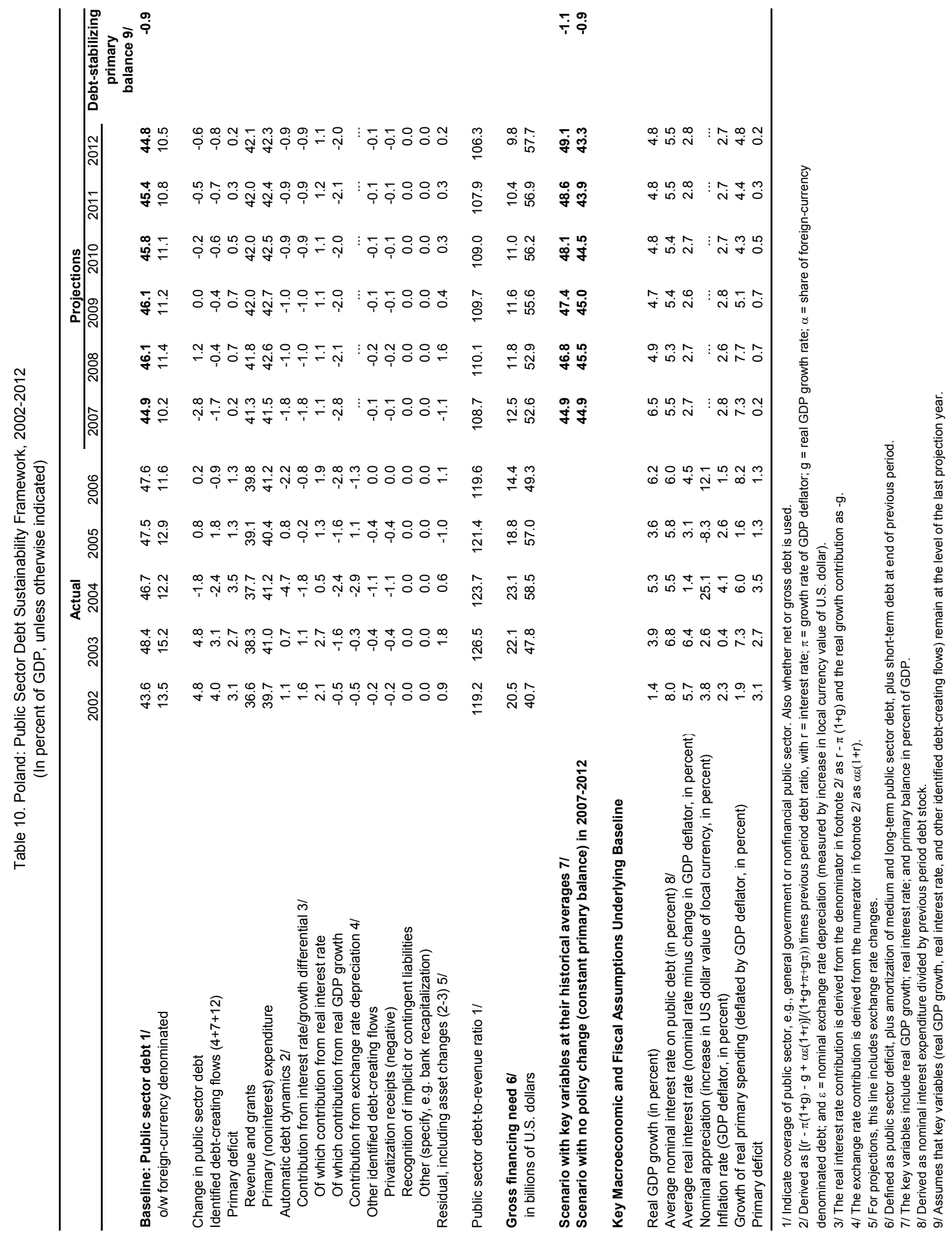


Table 11. Poland: Indicators of External Vulnerability, 2002-07 (In percent of GDP, unless otherwise indicated)

\begin{tabular}{|c|c|c|c|c|c|c|c|}
\hline & 2002 & 2003 & 2004 & 2005 & 2006 & $\begin{array}{l}2007 \\
\text { Proj. }\end{array}$ & $\begin{array}{c}\text { Date of } \\
\text { Observation }\end{array}$ \\
\hline \multicolumn{8}{|l|}{ Financial indicators } \\
\hline Public sector debt (in percent of GDP) $1 /$ & 43.6 & 48.4 & 46.7 & 47.5 & 47.6 & 44.2 & Proj. for 2007 \\
\hline Broad money (percent change, 12-month basis) & -1.1 & 5.8 & 9.4 & 13.1 & 16.0 & 13.6 & Nov-07 \\
\hline Private sector credit (percent change, 12 month basis) & 4.4 & 7.9 & 2.9 & 12.6 & 22.9 & 29.7 & Nov-07 \\
\hline Domestic credit to GDP & 32.3 & 33.2 & 32.9 & 33.6 & 38.7 & 44.9 & Dec-07 \\
\hline 3 month WIBO rate $2 /$ & 6.4 & 5.5 & 6.5 & 4.6 & 4.2 & 5.7 & Dec-07 \\
\hline 3 month WIBO real rate $3 /$ & 5.9 & 3.7 & 2.0 & 3.9 & 2.8 & 1.6 & Dec-07 \\
\hline \multicolumn{8}{|l|}{ External Indicators } \\
\hline Exports (percent change, 12-month basis in US\$) & 10.4 & 27.1 & 32.1 & 18.2 & 22.5 & 27.1 & Proj. for 2007 \\
\hline Imports (percent change, 12-month basis in US\$) & 8.4 & 22.5 & 29.2 & 13.5 & 25.9 & 27.8 & Proj. for 2007 \\
\hline Current account balance & -2.5 & -2.1 & -4.2 & -1.6 & -3.2 & -3.7 & Proj. for 2007 \\
\hline Capital and financial account balance & 3.6 & 4.0 & 3.8 & 5.4 & 4.2 & 8.3 & Proj. for 2007 \\
\hline o/w: Inward portfolio investment (debt securities etc.) & 1.5 & 1.7 & 4.2 & 5.0 & 0.5 & 0.1 & Proj. for 2007 \\
\hline Other investment (loans, trade credits etc.) & 0.2 & 1.5 & -0.5 & -0.6 & 2.8 & 5.7 & Proj. for 2007 \\
\hline Inward foreign direct investment & 2.1 & 2.1 & 5.2 & 3.4 & 5.6 & 4.5 & Proj. for 2007 \\
\hline Net Foreign Assets (NFA) of commercial banks (in billions of US\$) & 33.8 & 35.9 & 46.9 & 54.1 & 58.3 & $\ldots$ & \\
\hline Official reserves (in billions US\$) & 29.8 & 34.2 & 36.8 & 42.6 & 48.5 & 65.7 & Dec-07 \\
\hline Official reserves in months of imports of goods & 6.6 & 6.1 & 5.0 & 5.2 & 4.7 & 4.9 & Proj. for 2007 \\
\hline Reserve money to reserves (Ratio) & 0.5 & 0.5 & 0.6 & 0.5 & 0.6 & 0.7 & Nov-07 \\
\hline Broad money to reserves (Ratio) & 2.6 & 2.6 & 2.8 & 3.1 & 3.3 & $\ldots$ & \\
\hline Reserves to total short term external debt (in percent) 4 / & 123.1 & 105.6 & 106.3 & 101.8 & 97.4 & 103.7 & Proj. for 2007 \\
\hline Total external debt (in billions of US\$) & 84.9 & 107.3 & 129.8 & 132.8 & 169.3 & 229.9 & Proj. for 2007 \\
\hline o/w: Central and local government debt (in billions of US\$) & 35.7 & 44.0 & 57.7 & 58.9 & $\ldots$ & $\ldots$ & \\
\hline Ratio of short-term external debt to total external debt (in percent) & 16.3 & 18.3 & 19.1 & 20.3 & 20.3 & $\cdots$ & \\
\hline Exchange rate (per US\$, period average) & 4.1 & 3.9 & 3.7 & 3.2 & 3.1 & 2.8 & Dec-07 \\
\hline REER depreciation (-) (12-month growth, period average) 5/ & -4.1 & -10.9 & -0.1 & 11.7 & 2.2 & 3.5 & Nov-07 \\
\hline \multicolumn{8}{|l|}{ Financial Market Indicators } \\
\hline Stock market index (WIG) & 13,845 & 20,820 & 26,636 & 35,601 & 50,412 & 55,649 & Dec-07 \\
\hline \multicolumn{8}{|l|}{ Foreign currency debt rating } \\
\hline Standard and Poor's 6/ & $\mathrm{BBB}+$ & $\mathrm{BBB}+$ & $\mathrm{BBB}+$ & $\mathrm{BBB}+$ & $\mathrm{BBB}+$ & A- & Dec-07 \\
\hline Moody's $7 /$ & A2 & A2 & A2 & A2 & A2 & A2 & Dec-07 \\
\hline Spread, JP Morgan's EMBI index & 185 & 69 & 65 & 60 & 47 & 50 & Apr-07 \\
\hline $\begin{array}{l}\text { Sources: Bloomberg; Polish authorities; and IMF staff estimates and ca } \\
\text { 1/ Polish definition of public debt including the risk-weighted stock of gu } \\
\text { 2/ End-of-period. } \\
\text { 3/ Backward-looking with actual CPI. } \\
\text { 4/ By remaining maturity. } \\
\text { 5/ CPI based, using } 1999 \text { trade weights. } \\
\text { 6/ In Standard \& Poor's rating system BBB- is investment grade wherea } \\
\text { 7/ In Moody's rating system Baa is investment grade whereas Ba is bel }\end{array}$ & $\begin{array}{l}\text { ations. } \\
\text { ntees. }\end{array}$ & & & & & & \\
\hline
\end{tabular}




\section{INTERNATIONAL MONETARY FUND \\ REPUBLIC OF POLAND \\ Staff Report for the 2007 Article IV Consultation-Informational Annexes}

Prepared by the European Department

March 19, 2008

Contents

Page

Appendixes

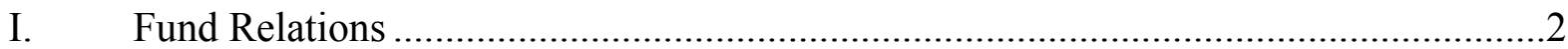

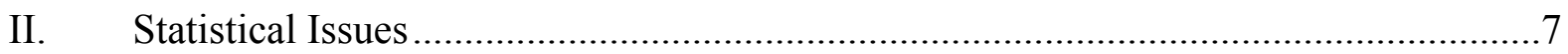




\section{Appendix I. Poland: Fund Relations}

(As of January 31, 2008)

I. Membership Status: Joined 6/12/86; Article VIII

II. General Resources Account:

SDR Million

Quota

Fund holdings of currency

Reserve position in Fund

III. SDR Department

$1,369.00$

$1,279.43$

89.59
SDR Million

Holdings

63.75
IV. Outstanding Purchases and Loans: None

V. Latest Financial Arrangements:

$\begin{array}{cc}\text { Approval } & \text { Expiration } \\ \text { Date } & \text { Date }\end{array}$

$\begin{array}{lll}\text { Stand-By } & 8 / 05 / 94 & 3 / 04 / 96 \\ \text { Stand-By } & 3 / 08 / 93 & 4 / 08 / 94 \\ \text { EFF } & 4 / 18 / 91 & 3 / 08 / 93\end{array}$

VI. Projected Obligations to Fund: None

VII. Exchange Rate Arrangement:
Percent

Quota

100.0

93.46

6.54
Percent

Allocation

N/A

$\begin{array}{cc}\begin{array}{c}\text { Amount } \\ \text { Approved } \\ \text { (SDR Million) }\end{array} & \begin{array}{c}\text { Amount } \\ \text { Drawn } \\ \text { (SDR Million) }\end{array} \\ 333.30 & 283.30 \\ 476.00 & 357.00 \\ 1,224.00 & 76.50\end{array}$

Poland accepted the obligation of Article VIII, Sections 2, 3, and 4 on June 1, 1995. The exchange system is free of restrictions on the making of payments and transfers for current international transactions.

Since April 12, 2000, the zloty has floated freely.

Prior to that, the zloty had been pegged to a currency composite made up of the U.S. dollar, deutsche mark, pound sterling, French franc, and the Swiss franc. As of January 1, 1999, the currency composite was changed to a basket comprised of 55 percent Euro and 45 percent U.S. dollar. From January 1, 1995, the zloty was redenominated, with new Z1 1 equaling old $\mathrm{Zl} 10,000$. The central parity of the zloty was adjusted under a crawling peg policy at a preannounced monthly rate. On May 16, 1995, a band of \pm 7 percent was introduced around the central rate. Following the implementation of the new system, the zloty initially appreciated by about 5 percent above the central rate. In September 1995, the exchange rate was allowed to appreciate a further 1 percent within the band. In December 1995, the central parity was raised by 6 percent, and at the same time the authorities allowed the actual exchange rate to appreciate by 22 percentage points. On January 8, 1996 the monthly rate of crawl was reduced to one percent. On February 26, 1998, with the zloty pushing towards its upper limit, 
the newly-formed Monetary Policy Council (RPP) widened the fluctuation band from \pm 7 percent to \pm 10 percent. At the same time, the rate of crawl was reduced from one percent to 0.8 percent per month. On July 17,1998 , the crawling peg's monthly rate of depreciation was cut from 0.8 percent to 0.65 percent. On September 9, 1998, the monthly rate of depreciation was reduced further to 0.50 percent. On October 29, 1998, the zlotys trading band was widened to 12.5 percent. On March 25, 1999, the zloty's trading band was widened to \pm 15 percent, and the rate of crawl was lowered to 0.3 percent per month. On December 31, 1999, the official rate was PLN 4.08 per US\$1. On April 12, 2000, the crawling band regime was abolished and the zloty has since floated freely.

Poland maintains an exchange system free of restrictions on the making of payments and transfers for current international transactions, except for the exchange restrictions imposed by Poland solely for the preservation of national or international security that have been notified to the Fund pursuant to Executive Board Decision No. 144-(52/51). Those exchange restrictions are contained in the following legal instruments:

- $\quad$ Council Regulation (EC) No. 2488/2000 of November 14, 2000, as amended (freezing of funds and economic resources of former Yugoslav President Slobodan Milosevic and certain other natural persons).

- $\quad$ Council Regulation (EC) No. 2580/2001 of December 28, 2001, as amended (freezing of funds and economic resources of certain persons, groups and entities with a view to combating terrorism).

- $\quad$ Council Regulation (EC) No. 881/2002 of May 29, 2002, as amended (freezing of funds and economic resources of persons and entities associated with Osama bin Laden, the Taliban and Al-Qaida).

- $\quad$ Council Regulation (EC) No. 1210/2003 of July 8, 2003, as amended (freezing of funds and economic resources of certain persons and entities in respect of Iraq).

- $\quad$ Council Regulation (EC) No. 314/2004 of February 24, 2004, as amended (freezing of funds and economic resources in respect of Zimbabwe).

- $\quad$ Council Regulation (EC) No. 798/2004 of April 28, 2004, as amended (freezing of funds and economic resources in respect of Burma/Myanmar).

- $\quad$ Council Regulation (EC) No. 872/2004 of April 30, 2004, as amended (freezing of funds and economic resources of persons and entities associated with Liberia's former President Taylor).

- $\quad$ Council Regulation (EC) No. 1763/2004 of October 14, 2004, as amended (freezing of funds and economic resources of certain persons indicted by the International Criminal Tribunal for the former Yugoslavia). 
- $\quad$ Council Regulation (EC) No. 560/2005 of April 14, 2005 (freezing of funds and economic resources of certain persons who constitute a threat to the peace and national reconciliation process in Côte d'Ivoire).

\section{Article IV Consultation}

The last Article IV consultation was concluded on October 4, 2006. In concluding the consultation, Directors welcomed the upswing in the Polish economy that has been developing since mid-2005, but encouraged the authorities to move decisively to increase the flexibility of the economy, resume the privatization process and help secure a favorable setting for Euro adoption. Directors expressed concerns about governance in the new law on financial supervision and urged the authorities to send a strong signal in the implementation of the legislation by committing to high standards of supervision.

\section{Technical Assistance, 1992-2007}

\begin{tabular}{|c|c|c|c|c|}
\hline Department & $\begin{array}{l}\text { Subject/Identified Need } \\
\text { Counterpart }\end{array}$ & Action & Timing & \\
\hline $\begin{array}{l}\text { MAE- } \\
\text { Coordinated }\end{array}$ & $\begin{array}{l}\text { Periodic visits by experts } \\
\text { from central banks cooperating } \\
\text { in providing technical assistance } \\
\text { to the NBP under the } \\
\text { coordination of MAE }\end{array}$ & $\begin{array}{l}\text { Experts' } \\
\text { visits }\end{array}$ & 1992-94 & NBP \\
\hline MAE & $\begin{array}{l}\text { Payments system, banking } \\
\text { supervision, monetary } \\
\text { research and analysis }\end{array}$ & Mission & May 1992 & NBP \\
\hline MAE & $\begin{array}{l}\text { Review of progress in the } \\
\text { modernization of operational } \\
\text { functions }\end{array}$ & Mission & Oct. 1992 & NBP \\
\hline MAE & $\begin{array}{l}\text { Resident expert-Advisor to } \\
\text { President of NBP }\end{array}$ & & Nov. 1991-92 & NBP \\
\hline MAE & $\begin{array}{l}\text { Additional steps in the } \\
\text { modernization process of } \\
\text { the NBP }\end{array}$ & Mission & April 1993 & NBP \\
\hline MAE & $\begin{array}{l}\text { Monetary programming and } \\
\text { operations, and payments } \\
\text { system }\end{array}$ & Mission & Nov. 1993 & NBP \\
\hline MAE & Central bank modernization & Mission & August 1994 & NBP \\
\hline MAE/LEG & $\begin{array}{l}\text { Review of the exchange and } \\
\text { payments system }\end{array}$ & Mission & February 1995 & $\begin{array}{l}\mathrm{NBP} / \\
\mathrm{MoF}\end{array}$ \\
\hline MAE & Exchange rate system & Mission & March 1995 & NBP \\
\hline
\end{tabular}




\begin{tabular}{|c|c|c|c|c|}
\hline MAE & $\begin{array}{l}\text { Review of government } \\
\text { securities market, payments } \\
\text { system and public debt } \\
\text { management }\end{array}$ & Mission & August 1995 & $\begin{array}{l}\mathrm{NBP} / \\
\mathrm{MoF}\end{array}$ \\
\hline MAE & $\begin{array}{l}\text { Asset consolidation exercise } \\
\text { visits }\end{array}$ & Expert & Late 1995 & NBP \\
\hline FAD & $\begin{array}{l}\text { Tax administration (VAT) } \\
\text { short-term assignments } \\
\text { of field experts }\end{array}$ & $\begin{array}{l}\text { Nine } \\
\text { October } 1994\end{array}$ & August 1992- & $\mathrm{MoF}$ \\
\hline FAD & Tax administration & Mission & November 1992 & $\mathrm{MoF}$ \\
\hline STA & $\begin{array}{l}\text { Framework for monetary } \\
\text { statistics }\end{array}$ & Mission & February 1993 & NBP \\
\hline STA & $\begin{array}{l}\text { Framework for monetary } \\
\text { statistics (follow-up) }\end{array}$ & Mission & November 1993 & NBP \\
\hline STA & $\begin{array}{l}\text { Government finance } \\
\text { Statistics }\end{array}$ & Mission & August 1995 & $\begin{array}{l}\mathrm{NBP} / \\
\mathrm{MoF}\end{array}$ \\
\hline STA & Money and banking statistics & Mission & January 1996 & NBP \\
\hline STA & $\begin{array}{l}\text { Government finance } \\
\text { statistics }\end{array}$ & Mission & July 1996 & $\begin{array}{l}\mathrm{NBP} / \\
\mathrm{MoF}\end{array}$ \\
\hline STA & Balance of payments statistics & Mission & November 1996 & $\begin{array}{l}\mathrm{NBP} / \\
\mathrm{MoF}\end{array}$ \\
\hline STA & $\begin{array}{l}\text { Balance of payments statistics } \\
\text { Mission }\end{array}$ & Follow-up & April 1997 & $\begin{array}{l}\mathrm{NBP} / \\
\mathrm{MoF}\end{array}$ \\
\hline STA & $\begin{array}{l}\text { Review of progress in } \\
\text { implementing the SDDS }\end{array}$ & Visit & February 1998 & \\
\hline FAD & Public expenditure management & Mission & April 1998 & $\mathrm{MoF}$ \\
\hline MAE & $\begin{array}{l}\text { Operational aspects of monetary } \\
\text { and exchange rate policy }\end{array}$ & Mission & September 1998 & NBP \\
\hline FAD & Tax administration & Mission & October 1998 & $\mathrm{MoF}$ \\
\hline FAD & $\begin{array}{l}\text { Examination of impact on } \\
\text { revenues of proposed tax reform }\end{array}$ & Mission & November 1998 & $\mathrm{MoF}$ \\
\hline FAD & Discussion of tax administration & Mission & March 1999 & $\mathrm{MoF}$ \\
\hline FAD & Tax administration seminar & Mission & April 1999 & $\mathrm{MoF}$ \\
\hline STA & $\begin{array}{l}\text { Government Finance Statistics } \\
\text { MoF/Local }\end{array}$ & Mission & October 1999 & \\
\hline FAD & $\begin{array}{l}\text { Tax administration- } \\
\text { Introduction of expert }\end{array}$ & Mission & November 1999 & $\mathrm{MoF}$ \\
\hline
\end{tabular}




\begin{tabular}{lllll} 
FAD & Administering Social Security & Mission & March 2000 & MoF \\
IMF/IBRD & FSAP & Mission & May \& Sept 2000 & MoF \\
& & & NBP \\
MAE & Monetary Operations & Mission & July 2001 & NBP \\
FAD & Expenditure restructuring & Mission & December 2001 & MoF \\
MAE & Stress testing & Mission & January 2002 & NBP \\
STA & Data ROSC & Mission & January 2003 & CSO/ \\
& & & & MoF/ \\
& & & & NBP \\
STA & Government finance & Mission & October 2003 & \\
& Statistics (GFSM 2001) & & & MoF \\
IMF/IBRD & FSAP Update & Mission & April/May 2006 & NBP \\
& & & & \\
\hline
\end{tabular}

\section{Resident Representative}

Mr. Christoph Rosenberg, the Senior Regional Resident Representative for central and eastern Europe, took up his duties in Warsaw in February 2005. 


\section{Appendix II. Poland: Statistical Issues}

1. Poland has a comprehensive macroeconomic database that has been improving in recent years and is adequate for surveillance. The authorities publish a full range of economic and financial statistics, and cooperate fully in providing data to the Fund. Data on the core indicators are available on a timely basis (see the attached Table of Common Indicators Required for Surveillance). Consistent with its commitment to provide a comprehensive set of high quality data, in an open manner, the country subscribes to the IMF's Special Data Dissemination Standard (SDDS) and its metadata are posted on the Fund's Dissemination Standards Bulletin Board.

\section{Real sector statistics}

2. The Central Statistical Office (GUS) compiles a wide range of real sector statistics, most of which are published promptly in the monthly Statistical Bulletin. The main problems for users include (i) the short span of comparable data series, reflecting the upheavals associated with transition to a market economy; (ii) inconsistencies between annual and higher frequency data, reflecting differences in weights and in coverage; and (iii) lack of easy electronic retrieval of these data.

3. The national accounts follow the concepts and definitions of the European System of Accounts 1995 (ESA 95), which is based on the System of National Accounts 1993 (SNA 1993). The GUS compiles annual and quarterly GDP estimates by the production and expenditure approaches in current and constant prices, a full set of accounts by institutional sectors, supply and use tables, input/output tables, annual financial accounts, and regional accounts. The statistical techniques are basically sound. The constant price estimates are compiled in average prices of the previous year, using deflation techniques that generally follow international standards. However, national accounts data still have some problemsthe subannual data are collected on a cumulative rather than on a discrete basis, and plans to introduce proper benchmarking have been delayed. In addition, seasonal adjustment on relatively short period leads to frequent and large backward revisions.

4. The concepts and definitions of the CPI follow the ESA 95 standards and Eurostat's requirements for the Harmonized Consumer Price Index. The CPI does not cover the imputed rents of owner-occupied dwellings. The weights for the index are obtained from the average annual expenditures primarily taken from the national Household Budget Survey (HBS) of the previous calendar year, and are updated annually. From 1999 onwards, the national classification is based on the Classification of Individual Consumption by Purpose (COICOP). The scope of the index covers all resident households, except those in some rural areas. Historical series are constructed using a chain method. Time series data are available for the index with reference periods of 1990 and 1998.

5. The producer price index (PPI) is based on the 1993 SNA concepts and definitions for recording and valuation of product prices and weights. Its scope includes mining and quarrying, manufacturing and electricity, gas and water supply. Output price indices are also calculated for agriculture, construction, and business services such as transport, storage, and 
communication. Since 2000, the index is classified by the Polish Classification of Activities based on the General Industrial Classification of Economic Activities within the European Communities, first revision (NACE, Rev.1), the Classification of Products by Activity, and the List of Products of the European Communities. The PPI does not include any estimation for missing prices or quality and seasonal adjustments.

\section{Government finance statistics}

6. The Ministry of Finance (MoF) provides detailed monthly state budget data on its website, compiled on a cash basis. Fiscal data for other levels of government are published or provided to IMF missions on a less frequent basis. Consolidated general government data are published only on an annual basis, at the time of the budget, as an estimated outturn at the time of the preparation of the next budget, and as the final outturn in late spring of the following year. The limited breakdown of expenditure by category hinders fiscal analysis and identification of priority areas for fiscal consolidation; consequently they play a very limited role in the public policy debate, although non-state budget expenditure accounts for a large share of general government expenditure.

7. Data for inclusion in the Government Finance Statistics Yearbook are reported to the Fund on a regular basis and, since 2004, according to the framework of GFSM 2001. The authorities have provided comparable data, compiled on an accrual basis, for 2001-03. Monthly cash data on consolidated core operations of the central government are reported in the GFSM 2001 cash flow statement for the IFS. The Central Statistical Office also produces fiscal data according to the ESA95 methodology for submission to the EU and use in Poland's Stability Programs. However, GFS and ESA95 data, while providing a superior classification of revenues and expenditure, traditionally became available with long lags and only on an annual basis, diminishing their value for surveillance purposes. ${ }^{1}$

\section{Monetary statistics}

8. The National Bank of Poland (NBP) regularly reports analytically useful data to the Fund with minimal delay. High-frequency data (every ten days) on the central bank balance sheet and the monetary survey are also available with minimal delay. As a member of the European Union, the country has adopted the recommendations of the European Central Bank (ECB) for the compilation of monetary and financial statistics; data compiled from March 2002 onward are generally consistent with the ECB framework, and previously released data have been revised back to December 1996.

9. The mission that prepared the data module of the Report on the Observance of Standards and Codes (ROSC) in January 2003 found that the concepts and definitions used by the NBP to compile monetary statistics were in broad conformity with the guidelines outlined in the Monetary and Financial Statistics Manual (MFSM). Nevertheless, the following concepts and principles underlying valuation and classification of financial

\footnotetext{
${ }^{1}$ In 2007, STA and Eurostat finalized bridging the annual ESA and GFS data for all EU countries.
} 
instruments deviate from the MFSM: (i) financial derivatives are indistinguishably recorded under other assets/other liabilities; (ii) accrued interest on loans and deposits are included as part of other assets/other liabilities, but not with the respective underlying instruments; (iii) similarly accrued interest on securities other than shares issued by the depository corporations are included as part of other liabilities; (iv) loan-loss provisions are classified as special reserves under capital accounts and reserves; and (v) valuation of shares and other equity on the asset side of the balance sheets of the NBP and other depository corporations is not at market prices. The first three practices differ from the MFSM guidelines, but are in conformity with the ECB framework.

10. Regarding financing data, the ROSC mission noted material differences between government finance statistics and the corresponding monetary data. The data ROSC mission recommended that the NBP, in cooperation with the MoF, reconcile monetary and government finance statistics and carry out a reconciliation exercise on a regular basis.

11. Compiled monetary data, based on the SRFs, have been published in the February 2008 issue of the IFS Supplement. The new data provide breakdowns of the claims on, and liabilities to the central government and general government, which were previously not available. However, breakdowns of the claims on, and liabilities to, other resident sectors are not available.

\section{External sector statistics}

12. While improvements have been made in the balance of payments data, some issues need to be addressed. While there are valid differences in definitions between the customs (GUS) and payment-based trade data compiled by the NBP, the two data sources need to be further cross-checked for broad consistency. The NBP now reports net foreign assets rather than the net international reserves previously shown in the monetary survey. Also, the coverage and reporting of the stock of external debt, especially at maturities up to one year, could be improved. The 2003 data ROSC mission recommended including interest on an accrual basis, making explicit the legal requirement that the NBP disseminate balance of payments statistics, separating insurance from transportation when making the c.i.f./f.o.b. adjustment, publishing on a regular basis a reconciliation table between international merchandise trade statistics and "goods" in the balance of payments, and undertaking periodic revision studies. 


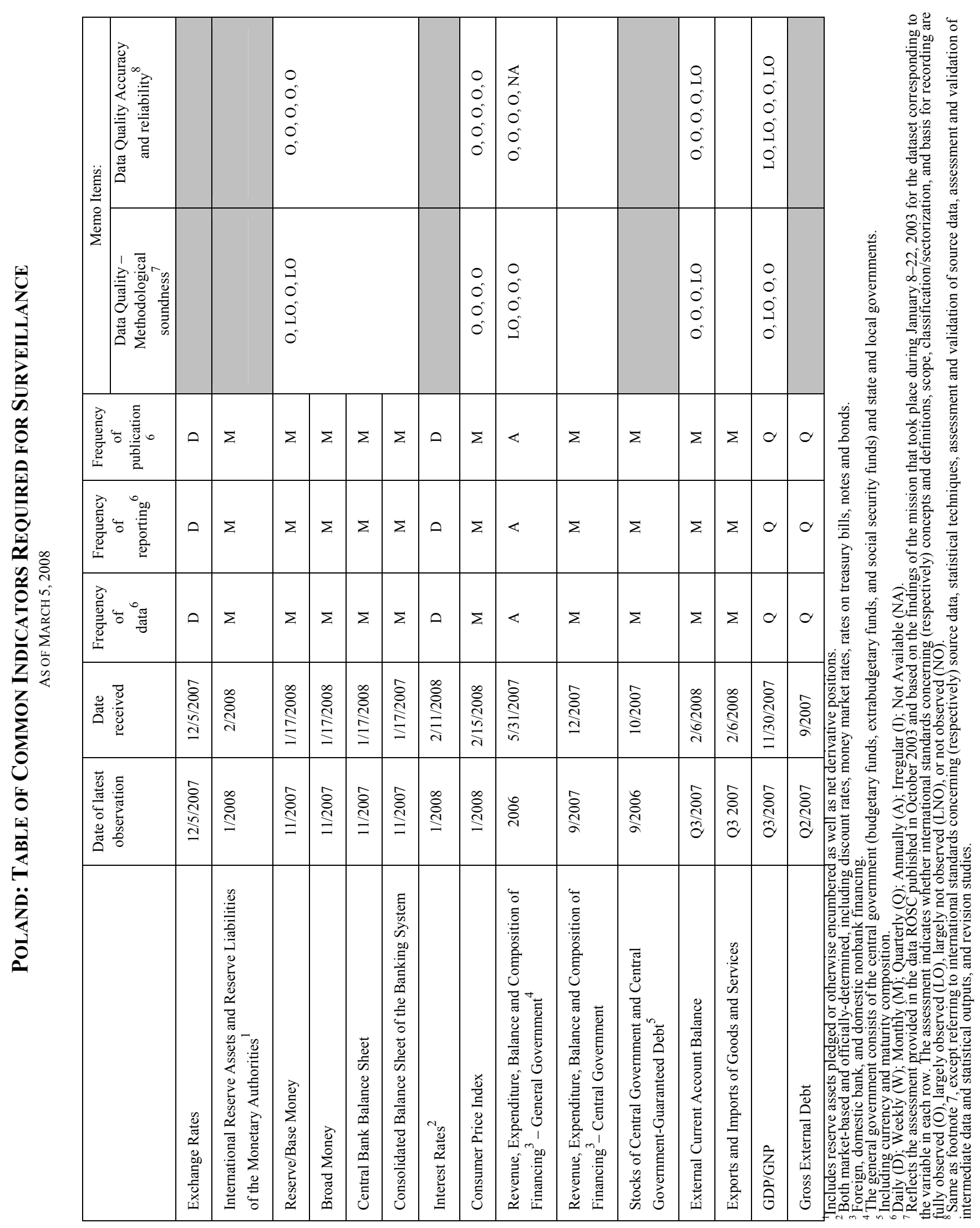




\title{
INTERNATIONAL MONETARY FUND
}

\section{POLAND \\ Staff Report for the 2007 Article IV Consultation Supplementary Information}

\author{
Prepared by the European Department \\ (In consultation with the Policy Development and Review Department) \\ Approved by Michael Deppler and Adnan Mazarei
}

April 9, 2008

This supplement to the staff report for the 2007 Article IV consultation with Poland provides information on recent developments and discusses the implications of these developments for the economic outlook and for monetary policy.

\section{Summary}

Recent data suggest that GDP growth, as well as inflationary and wage pressures, have been stronger going into 2008 than assumed in the staff's baseline scenario. There is also still no evidence of a notable impact of the global market turmoil on Poland. However, in view of the expected slowdown in major export markets, staff has reduced its GDP growth forecast and slightly lowered its end-year inflation forecast for 2009. Following a further increase in policy interest rates recently, the third increase this year, a continuation of the tightening cycle will depend on whether wage pressures ease in the coming months.

\section{Recent Developments}

1. GDP growth remains robust; inflationary pressures are not abating; and there are no signs of substantial spillovers from the global turmoil through real or financial channels:

- $\quad$ High-frequency indicators point to stronger GDP growth than assumed in staff's baseline scenario. Growth in industrial production is slowing less than expected, retail sales remain very strong, and exports have continued to grow.

- Inflation is still rising. Head-line inflation increased to 4.2 percent (year-on-year) in February. This is significantly above the central target of 2.5 percent and well outside the NBP's upper tolerance limit of $3 \frac{1}{2}$ percent for deviations from this target. Core- 
inflation is estimated to have risen from 1.7 percent at end-2007 to 2.5 percent at endFebruary.

- Labor markets have continued to tighten. Employment is still increasing, and nominal wage increases rebounded to above 10 percent (year-on-year) in January-February, having temporarily slowed in December.

- The global turmoil has lead to some further increase in credit default swap and bond spreads, with the latter increasing about 30 basis points since the beginning of 2008 . Credit growth, however, is still largely unaffected, with credit to the household and corporate sectors growing by about 30 and 20 percent, respectively, in real terms.

\section{Monetary and fiscal policies}

2. The monetary tightening cycle has continued. The Monetary Policy Council (MPC) recently increased the policy rate by 25 basis points, the third such increase since the beginning of year, stressing the further rise in inflation and pressures in the labor market. The policy rate now stands at 5.75 percent, 175 basis points higher that in April 2007, when the tightening cycle began. Despite the further tightening, the zloty has appreciated by less than 3 percent versus the euro since the beginning of the year.

3. Fiscal policy is still set to add some stimulus in 2008. Recent data point to a betterthan-budgeted fiscal position in 2008, as anticipated in the Staff Report. In particular, March CIT receipts were larger than projected, thanks to continuous strong corporate profits, while expenditure execution has so far been lower than anticipated. Staff nonetheless now projects a somewhat larger fiscal stimulus in 2008 - of about $1 / 2$ percent of GDP-because the fiscal outcome for 2007 was somewhat better than anticipated. As to other fiscal issues, the authorities' updated Convergence Program targets a deficit of 1 percent of GDP by 2011, consistent with their commitment to a more ambitious fiscal consolidation path. Also, following up on staff's recommendation to strengthen the medium-term fiscal framework, an FAD technical assistance mission visited Warsaw in late March and left the authorities an aide-memoire providing advice on implementing such a framework, including establishing expenditure ceilings.

\section{Revisions to the outlook}

4. Staff has reduced its projection for GDP growth in 2009. Driven by the downward revisions to euro area growth projections in the Spring WEO, staff expects export growth to slow moderately compared to the baseline forecast in the staff report, starting in the second half of 2008. This slowdown is expected to largely offset the stronger GDP growth evident from data going into 2008 — staff has maintained its GDP growth forecast of 4.9 percent for 2008. In 2009, however, the slower export growth is expected to translate into a reduction in GDP growth to 4.5 percent, which is a reduction of about $1 / 4$ percentage point relative to the previous baseline. 


\section{Despite the higher inflationary pressures at this time, staff expects a modest} easing compared to its baseline inflation forecast for 2009. In view of higher-thanexpected inflation in early 2008, staff has increased its forecast for 2008 from 3.8 percent to 4.0 percent (year average). However, consistent with the lowering of the GDP forecast for next year, the projected rate of inflation by end-2009 has been lowered from 3.7 percent to 3.5 percent.

\section{Staff assessment}

6. The change in external outlook poses a challenge for monetary policy. The negative spillovers from the expected slowdown in export markets, together with the delayed impact of the recent monetary tightening, will slow baseline GDP growth to slightly below its estimated potential next year. This together with the projected stabilization of commodity prices should eventually lead to a gradual easing of inflationary pressures. However, while staff believes that the risks to its baseline growth forecast are equally balanced at this stage, it is concerned about near term upside risks to its inflation forecast. In particular, the continued tightening of labor markets and increase in core inflation evident from recent data point to the risk, as discussed in the staff report, that the strong increase in ULC that has been under way will increasingly be reflected in prices because the scope for compressing profit margins might have run its course. In view of this, a continuation of double digit wage increases and rising core inflation in the coming months would, in staff's view, warrant additional tightening. The slightly higher fiscal stimulus in store for 2008 will increase the burden on monetary policy but not appreciably so.

\section{The weakening of the external outlook has not changed long-term challenges.}

Most important in this regard is preserving competitiveness by containing demand pressures, while raising potential growth by boosting the labor supply. From this perspective, Staff welcomes that the update of the Convergence Program includes a more ambitious mediumterm target for fiscal consolidation than what was envisaged in the previous version. 
Table 1. Poland: Selected Economic Indicators, 2002-09

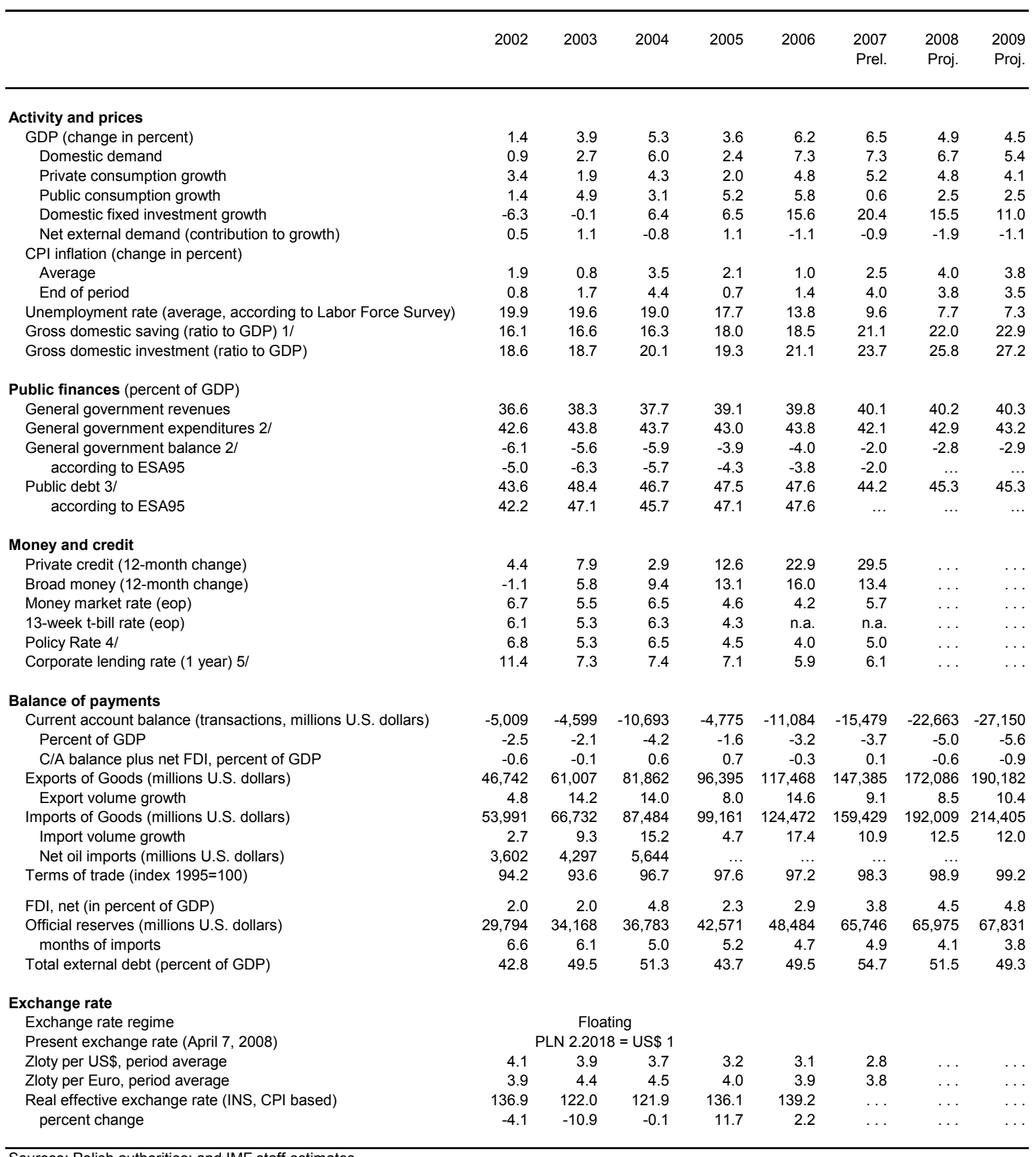

Sources: Polish authorities; and IMF staff estimates.

$1 /$ Derived as total savings minus the current account minus capital transfers.

2/ Fund definition (including pension reform costs).

3/ Polish definition of debt including risk weighted stock of outstanding guarantees

4/ Yield on 7-day NBP money market bills.

5/ The methodology for computing interest rates was changed in 2004 to fulfil ECB requirements. 


\section{INTERNATIONAL MONETARY FUND}

Public Information Notice

EXTERNAL

RELATIONS

DEPARTMENT

Public Information Notice (PIN) No. 08/xx

FOR IMMEDIATE RELEASE
International Monetary Fund

$70019^{\text {th }}$ Street, NW

Washington, D. C. 20431 USA

\section{IMF Executive Board Concludes 2007 Article IV Consultation with the Republic of Poland}

On April 16, 2008, the Executive Board of the International Monetary Fund (IMF) concluded the Article IV consultation with the Republic of Poland. ${ }^{1}$

\section{Background}

After two years of sluggish performance, Poland entered its second year of strong economic growth in 2007 . Output expanded by 6.5 percent, underpinned by robust and balanced growth in domestic demand. EU accession continued to bolster investors' confidence and private consumption was supported by several factors, notably rising real wages and record-high credit for Poland.

The external sector has been an increasing drag on the economy. Still, the current account deficit (33/4 percent of GDP) remains fully financed by FDI, and the underlying balance, estimated to be $4 \frac{1}{2}-6$ percent of GDP, is consistent with external-debt stabilizing levels. Moreover, staff estimates do not point to exchange rate misalignment, despite real appreciation since mid-2006.

\footnotetext{
${ }^{1}$ Under Article IV of the IMF's Articles of Agreement, the IMF holds bilateral discussions with members, usually every year. A staff team visits the country, collects economic and financial information, and discusses with officials the country's economic developments and policies. On return to headquarters, the staff prepares a report, which forms the basis for discussion by the Executive Board. At the conclusion of the discussion, the Managing Director, as Chairman of the Board, summarizes the views of Executive Directors, and this summary is transmitted to the country's authorities.
} 
Inflationary pressures are mounting, most evidently in the labor market. Unemployment fell by about 8 percentage points since early 2006 to about 9 percent—partly fuelled by emigration to Western Europe-and real wage growth has outstripped productivity gains starting in end-2007. So far, this has been largely absorbed through lower profit margins, but core inflation is estimated to have risen from about $13 / 4$ percent at end-2007 to $21 / 2$ percent at end-February. With fuel and food prices soaring, headline inflation picked at $41 / 4$ percent (year-on-year) in February, far above the $2 \frac{1}{2}$ percent target and beyond the $1 \frac{1}{2}-3 \frac{1}{2}$ percent inflation band.

Macroeconomic policies tightened in 2007. Adjusting for cyclical factors, fiscal tightening reached about $1 \frac{1}{2}$ percent of GDP, underpinned by expenditure under-execution. The general government deficit is estimated to have fallen to 2 percent of GDP. Meanwhile, reflecting concerns about rising inflation, policy interest rates were raised seven times since April 2007, to $5 \frac{3}{4}$ percent. Still, the increase in nominal rates has been insufficient to prevent real interest rate from falling in the face of accelerating inflation.

The turmoil in international capital markets has had only a limited impact in Poland. Spreads in bond and credit default swap have only risen moderately. In contrast, the stock market retrenchment has been severe, but it followed substantial gains since 2006. While strong domestic credit has increasingly been funded from abroad-consistent with the rising interest differential in favor of the zloty-the overall share of net foreign liabilities is still small and the banking system remains well capitalized and highly profitable. Stress tests show resilience of the banking system to a potential deterioration in the debt burdens of both households and corporates, even in the face of international shocks.

\section{Executive Board Assessment}

Directors noted that Poland is enjoying strong and well-balanced economic growth, in large part because of a boom in investment following EU accession. There have been only limited upward pressures on core inflation until recently, the external current account deficit is still relatively low, and the zloty has remained within its estimated equilibrium range.

At the same time, Directors noted that resource constraints are beginning to emerge. This is especially the case in the labor market, where real wage growth has outpaced productivity gains. The more recent uptick in core inflation suggests that there may be diminishing scope for profits to absorb rising unit labor costs, and increased risks to competitiveness. The challenge facing the new government is thus to contain demand pressure, while boosting the economy's supply response, in particular by raising the exceptionally low rate of labor participation.

With output growth remaining robust and inflationary pressures continuing to be relatively high, Directors welcomed the tightening monetary policy cycle under way since last April. Looking forward, and noting that labor market pressures point to the risk of a 
wage-price spiral, Directors stressed the importance of ensuring that higher inflationary expectations do not get entrenched. They supported the authorities' intention to maintain the tightening bias in monetary policy in order to bring inflation back to target. Some Directors encouraged the authorities to enhance their communication policy to further strengthen monetary policy credibility. Directors welcomed the authorities' commitment to the adoption of the euro as soon as the necessary conditions are met on a sustainable basis.

Directors noted the importance of strengthening Poland's medium-term budgetary framework in order to facilitate the needed expenditure-based consolidation and safeguard against a pro-cyclical fiscal stance. They therefore welcomed the authorities' determination to speed up fiscal consolidation and reduce the structural fiscal deficit to 1 percent of GDP over the medium term. This would help unburden monetary policy, create appropriate cyclical safety margins, and reduce the risk to external sustainability in the event that the private sector's saving-investment balance deteriorates faster than expected over the medium-term. Some Directors saw scope for automatic stabilizers to work in the event that external spillovers cause growth to drop below potential, but a few others urged caution in allowing full play of automatic stabilizers in such circumstances.

Directors noted that the negative spillovers on the Polish economy from the global financial market turbulence have been limited so far. There have been some modest increases in credit default swap and bond spreads, but no major slowdown in credit volumes. Spillovers may have been contained because of the absence of exposure to the US sub-prime market, the limited use of advanced structured products, and the generally high profitability of banks, including the Polish subsidiaries of international banks. Directors also noted that the banking system is well capitalized, and that the overall share of foreign liabilities is small. Nevertheless, they called for continued vigilance.

Directors noted that the recent unification of supervisory functions under the auspices of the Financial Supervision Authority has come at a time when extra vigilance is essential. They called on the authorities to ensure that there are no disruptions in the timeliness and effectiveness of supervision. The Financial Supervision Authority should give priority to formalizing understandings with the National Bank of Poland and the Ministry of Finance on future cooperation.

Directors stressed that the key to boosting long-term growth will be to increase the exceptionally low labor market participation. They welcomed the authorities' intention to pursue reforms that would enhance work incentives, and encouraged them to move ahead with the formulation of such policies. Directors took note of the experience in other EU countries in which labor participation has been boosted with incremental improvements in areas such as product market regulation and the tax wedge. Some Directors pointed to the 
complementary effects of labor market reforms on medium-term fiscal consolidation.

Directors also welcomed the authorities' determination to restart the privatization program, and saw scope for further deregulation of the economy to catalyze more rapid productivity growth.

Directors found that the authorities' commitment to macroeconomic stability, reinvigoration of structural reforms, and the adoption of the euro augur well for Poland's prospects of taking full advantage of its EU membership.

Public Information Notices (PINs) form part of the IMF's efforts to promote transparency of the IMF's views and analysis of economic developments and policies. With the consent of the country (or countries) concerned, PINs are issued after Executive Board discussions of Article IV consultations with member countries, of its surveillance of developments at the regional level, of post-program monitoring, and of ex post assessments of member countries with longer-term program engagements. PINs are also issued after Executive Board discussions of general policy matters, unless otherwise decided by the Executive Board in a particular case. 
Poland: Selected Economic Indicators, 2004-08

\begin{tabular}{|c|c|c|c|c|c|}
\hline & 2004 & 2005 & 2006 & $\begin{array}{l}2007 \\
\text { Prel. }\end{array}$ & $\begin{array}{l}2008 \\
\text { Proj. }\end{array}$ \\
\hline Real economy (change in percent) & \multicolumn{5}{|c|}{ (Change in percent) } \\
\hline Real GDP & 5.3 & 3.6 & 6.2 & 6.5 & 4.9 \\
\hline Real domestic demand & 6.0 & 2.4 & 7.3 & 7.3 & 6.7 \\
\hline $\mathrm{CPI}$ (end of period) & 4.4 & 0.7 & 1.4 & 4.0 & 3.8 \\
\hline Unemployment rate (in percent) & 19.0 & 17.7 & 13.8 & 9.6 & 7.7 \\
\hline Gross national saving (percent of GDP) $1 /$ & 16.3 & 18.0 & 18.5 & 21.1 & 22.0 \\
\hline Gross domestic investment (percent of GDP) & 20.1 & 19.3 & 21.1 & 23.7 & 25.8 \\
\hline Public finances & \multicolumn{5}{|c|}{ (In percent of GDP) } \\
\hline General government balance 2/ & -5.9 & -3.9 & -4.0 & -2.0 & -2.8 \\
\hline according to ESA95 & -5.7 & -4.3 & -3.8 & -2.0 & $\ldots$ \\
\hline Public debt 3/ & 46.7 & 47.5 & 47.6 & 44.2 & 45.3 \\
\hline according to ESA95 & 45.7 & 47.1 & 47.6 & $\ldots$ & $\ldots$ \\
\hline Money and credit & \multicolumn{5}{|c|}{ (End of period, percent) } \\
\hline Private sector credit (12-month change) & 2.9 & 12.6 & 22.9 & 29.5 & $\ldots$ \\
\hline Broad money (12-month change) & 9.4 & 13.1 & 16.0 & 13.4 & $\ldots$ \\
\hline Money market rate (end of period) & 6.5 & 4.6 & 4.2 & 5.7 & $\ldots$ \\
\hline \multicolumn{6}{|l|}{ Balance of payments } \\
\hline Trade balance (in percent of GDP) & -2.2 & -0.9 & -2.0 & -2.9 & -4.3 \\
\hline Current account (in percent of GDP) & -4.2 & -1.6 & -3.2 & -3.7 & -5.0 \\
\hline Official reserves (in billions of U.S. dollars) & 36.8 & 42.6 & 48.5 & 65.7 & 66.0 \\
\hline Reserve cover (months of merchandise imports) & 5.0 & 5.2 & 4.7 & 4.9 & 4.1 \\
\hline Total external debt (percent of GDP) & 51.3 & 43.7 & 49.5 & 54.7 & 51.5 \\
\hline Fund position & \multicolumn{5}{|c|}{ (In millions of SDRs) } \\
\hline Quota & \multicolumn{5}{|c|}{$1,369.00$} \\
\hline Fund holdings of currency (January 31,2008 ) & \multicolumn{5}{|c|}{$1,279.43$} \\
\hline Holdings of SDRs (January 31,2008 ) & \multicolumn{5}{|c|}{89.59} \\
\hline \multicolumn{6}{|l|}{ Exchange rate } \\
\hline Exchange rate regime & \multicolumn{5}{|c|}{ Floating } \\
\hline Present exchange rate (March 18,2008$)$ & \multicolumn{5}{|c|}{ PLN $2.2018=$ US $\$ 1$} \\
\hline Zloty per U.S. dollar, period average & 3.7 & 3.2 & 3.1 & 2.8 & $\ldots$ \\
\hline Appreciation $(+)$ of real effective exchange rate & & & & & \\
\hline (CPI based, in percent) & -0.1 & 11.7 & 2.2 & 3.9 & $\ldots$ \\
\hline
\end{tabular}

Sources: Central Statistical Office; data provided by Polish authorities; and IMF staff estimates.

$1 /$ Derived as total savings minus the current account minus capital transfers.

2/ Fund definition (including the cost of the pension reform).

3/ Polish definition of debt including risk weighted stock of outstanding guarantees. 


\section{INTERNATIONAL MONETARY FUND}

EXTERNAL

RELATIONS

DEPARTMENT
Public Information Notice (PIN) No. 08/46

FOR IMMEDIATE RELEASE

April 18, 2008
International Monetary Fund $70019^{\text {th }}$ Street, NW

Washington, D. C. 20431 USA

\section{IMF Executive Board Concludes 2007 Article IV Consultation with the Republic of Poland}

On April 16, 2008, the Executive Board of the International Monetary Fund (IMF) concluded the Article IV consultation with the Republic of Poland. ${ }^{1}$

\section{Background}

After two years of sluggish performance, Poland entered its second year of strong economic growth in 2007 . Output expanded by 6.5 percent, underpinned by robust and balanced growth in domestic demand. EU accession continued to bolster investors' confidence and private consumption was supported by several factors, notably rising real wages and record-high credit for Poland.

The external sector has been an increasing drag on the economy. Still, the current account deficit ( $33 / 4$ percent of GDP) remains fully financed by foreign direct investment (FDI), and the underlying balance, estimated to be 4 $1 / 2-6$ percent of GDP, is consistent with external-debt stabilizing levels. Moreover, staff estimates do not point to exchange rate misalignment, despite real appreciation since mid-2006.

Inflationary pressures are mounting, most evidently in the labor market. Unemployment fell by about 8 percentage points since early 2006 to about 9 percent-partly fuelled by emigration to

\footnotetext{
${ }^{1}$ Under Article IV of the IMF's Articles of Agreement, the IMF holds bilateral discussions with members, usually every year. A staff team visits the country, collects economic and financial information, and discusses with officials the country's economic developments and policies. On return to headquarters, the staff prepares a report, which forms the basis for discussion by the Executive Board. At the conclusion of the discussion, the Managing Director, as Chairman of the Board, summarizes the views of Executive Directors, and this summary is transmitted to the country's authorities.
} 
Western Europe-and real wage growth has outstripped productivity gains starting in end-2007. So far, this has been largely absorbed through lower profit margins, but core inflation is estimated to have risen from about $13 / 4$ percent at end-2007 to $2 \frac{1}{2}$ percent at end-February. With fuel and food prices soaring, headline inflation picked at $4 \frac{1}{4}$ percent (year-on-year) in February, far above the $2 \frac{1}{2}$ percent target and beyond the $1 \frac{1}{2}-3 \frac{1}{2}$ percent inflation band.

Macroeconomic policies tightened in 2007. Adjusting for cyclical factors, fiscal tightening reached about $1 \frac{1}{2}$ percent of GDP, underpinned by expenditure under-execution. The general government deficit is estimated to have fallen to 2 percent of GDP. Meanwhile, reflecting concerns about rising inflation, policy interest rates were raised seven times since April 2007, to $53 / 4$ percent. Still, the increase in nominal rates has been insufficient to prevent real interest rate from falling in the face of accelerating inflation.

The turmoil in international capital markets has had only a limited impact in Poland. Spreads in bond and credit default swap have only risen moderately. In contrast, the stock market retrenchment has been severe, but it followed substantial gains since 2006 . While strong domestic credit has increasingly been funded from abroad-consistent with the rising interest differential in favor of the zloty-the overall share of net foreign liabilities is still small and the banking system remains well capitalized and highly profitable. Stress tests show resilience of the banking system to a potential deterioration in the debt burdens of both households and corporates, even in the face of international shocks.

\section{Executive Board Assessment}

Executive Directors noted that Poland is enjoying strong and well-balanced economic growth, in large part because of a boom in investment following EU accession. There have been only limited upward pressures on core inflation until recently, the external current account deficit is still relatively low, and the zloty has remained within its estimated equilibrium range.

At the same time, Directors noted that resource constraints are beginning to emerge. This is especially the case in the labor market, where real wage growth has outpaced productivity gains. The more recent uptick in core inflation suggests that there may be diminishing scope for profits to absorb rising unit labor costs, and increased risks to competitiveness. The challenge facing the new government is thus to contain demand pressure, while boosting the economy's supply response, in particular by raising the exceptionally low rate of labor participation.

With output growth remaining robust and inflationary pressures continuing to be relatively high, Directors welcomed the tightening monetary policy cycle under way since last April. Looking forward, and noting that labor market pressures point to the risk of a wage-price spiral, Directors stressed the importance of ensuring that higher inflationary expectations do not get entrenched. They supported the authorities' intention to maintain the tightening bias in monetary policy in order to bring inflation back to target. Some Directors encouraged the authorities to enhance their communication policy to further strengthen monetary policy credibility. Directors welcomed the authorities' commitment to the adoption of the euro as soon as the necessary conditions are met on a sustainable basis. 
Directors noted the importance of strengthening Poland's medium-term budgetary framework in order to facilitate the needed expenditure-based consolidation and safeguard against a procyclical fiscal stance. They therefore welcomed the authorities' determination to speed up fiscal consolidation and reduce the structural fiscal deficit to 1 percent of GDP over the medium term. This would help unburden monetary policy, create appropriate cyclical safety margins, and reduce the risk to external sustainability in the event that the private sector's saving-investment balance deteriorates faster than expected over the medium-term. Some Directors saw scope for automatic stabilizers to work in the event that external spillovers cause growth to drop below potential, but a few others urged caution in allowing full play of automatic stabilizers in such circumstances.

Directors noted that the negative spillovers on the Polish economy from the global financial market turbulence have been limited so far. There have been some modest increases in credit default swap and bond spreads, but no major slowdown in credit volumes. Spillovers may have been contained because of the absence of exposure to the US sub-prime market, the limited use of advanced structured products, and the generally high profitability of banks, including the Polish subsidiaries of international banks. Directors also noted that the banking system is well capitalized, and that the overall share of foreign liabilities is small. Nevertheless, they called for continued vigilance.

Directors noted that the recent unification of supervisory functions under the auspices of the Financial Supervision Authority has come at a time when extra vigilance is essential. They called on the authorities to ensure that there are no disruptions in the timeliness and effectiveness of supervision. The Financial Supervision Authority should give priority to formalizing understandings with the National Bank of Poland and the Ministry of Finance on future cooperation.

Directors stressed that the key to boosting long-term growth will be to increase the exceptionally low labor market participation. They welcomed the authorities' intention to pursue reforms that would enhance work incentives, and encouraged them to move ahead with the formulation of such policies. Directors took note of the experience in other EU countries in which labor participation has been boosted with incremental improvements in areas such as product market regulation and the tax wedge. Some Directors pointed to the complementary effects of labor market reforms on medium-term fiscal consolidation. Directors also welcomed the authorities' determination to restart the privatization program, and saw scope for further deregulation of the economy to catalyze more rapid productivity growth.

Directors found that the authorities' commitment to macroeconomic stability, reinvigoration of structural reforms, and the adoption of the euro augur well for Poland's prospects of taking full advantage of its EU membership. 
Public Information Notices (PINs) form part of the IMF's efforts to promote transparency of the IMF's views and analysis of economic developments and policies. With the consent of the country (or countries) concerned, PINs are issued after Executive Board discussions of Article IV consultations with member countries, of its surveillance of developments at the regional level, of post-program monitoring, and of ex post assessments of member countries with longer-term program engagements. PINs are also issued after Executive Board discussions of general policy matters, unless otherwise decided by the Executive Board in a particular case. The staff report (use the free Adobe Acrobat Reader to view this pdf file) for the 2007 Article IV Consultation with Poland is also available. 
Poland: Selected Economic Indicators, 2004-08

\begin{tabular}{|c|c|c|c|c|c|}
\hline & 2004 & 2005 & 2006 & $\begin{array}{l}2007 \\
\text { Prel. }\end{array}$ & $\begin{array}{l}2008 \\
\text { Proj. }\end{array}$ \\
\hline Real economy (change in percent) & \multicolumn{5}{|c|}{ (Change in percent) } \\
\hline Real GDP & 5.3 & 3.6 & 6.2 & 6.5 & 4.9 \\
\hline Real domestic demand & 6.0 & 2.4 & 7.3 & 7.3 & 6.7 \\
\hline CPI (end of period) & 4.4 & 0.7 & 1.4 & 4.0 & 3.8 \\
\hline Unemployment rate (in percent) & 19.0 & 17.7 & 13.8 & 9.6 & 7.7 \\
\hline Gross national saving (percent of GDP) 1/ & 16.3 & 18.0 & 18.5 & 21.1 & 22.0 \\
\hline Gross domestic investment (percent of GDP) & 20.1 & 19.3 & 21.1 & 23.7 & 25.8 \\
\hline Public finances & \multicolumn{5}{|c|}{ (In percent of GDP) } \\
\hline General government balance 2/ & -5.9 & -3.9 & -4.0 & -2.0 & -2.8 \\
\hline according to ESA95 & -5.7 & -4.3 & -3.8 & -2.0 & $\ldots$ \\
\hline Public debt 3/ & 46.7 & 47.5 & 47.6 & 44.2 & 45.3 \\
\hline according to ESA95 & 45.7 & 47.1 & 47.6 & $\ldots$ & $\ldots$ \\
\hline Money and credit & \multicolumn{5}{|c|}{ (End of period, percent) } \\
\hline Private sector credit (12-month change) & 2.9 & 12.6 & 22.9 & 29.5 & $\ldots$ \\
\hline Broad money (12-month change) & 9.4 & 13.1 & 16.0 & 13.4 & $\ldots$ \\
\hline Money market rate (end of period) & 6.5 & 4.6 & 4.2 & 5.7 & $\ldots$ \\
\hline \multicolumn{6}{|l|}{ Balance of payments } \\
\hline Trade balance (in percent of GDP) & -2.2 & -0.9 & -2.0 & -2.9 & -4.3 \\
\hline Current account (in percent of GDP) & -4.2 & -1.6 & -3.2 & -3.7 & -5.0 \\
\hline Official reserves (in billions of U.S. dollars) & 36.8 & 42.6 & 48.5 & 65.7 & 66.0 \\
\hline Reserve cover (months of merchandise imports) & 5.0 & 5.2 & 4.7 & 4.9 & 4.1 \\
\hline Total external debt (percent of GDP) & 51.3 & 43.7 & 49.5 & 54.7 & 51.5 \\
\hline Fund position & \multicolumn{5}{|c|}{ (In millions of SDRs) } \\
\hline Quota & \multicolumn{5}{|c|}{$1,369.00$} \\
\hline Fund holdings of currency (January 31,2008 ) & \multicolumn{5}{|c|}{$1,279.43$} \\
\hline Holdings of SDRs (January 31,2008 ) & \multicolumn{5}{|c|}{89.59} \\
\hline \multicolumn{6}{|l|}{ Exchange rate } \\
\hline Exchange rate regime & \multicolumn{5}{|c|}{ Floating } \\
\hline Present exchange rate (March 18,2008$)$ & \multicolumn{5}{|c|}{ PLN $2.2018=$ US $\$ 1$} \\
\hline Zloty per U.S. dollar, period average & 3.7 & 3.2 & 3.1 & 2.8 & $\ldots$ \\
\hline $\begin{array}{l}\text { Appreciation }(+) \text { of real effective exchange rate } \\
\text { (CPI based, in percent) }\end{array}$ & -0.1 & 11.7 & 2.2 & 3.9 & $\ldots$ \\
\hline
\end{tabular}

Sources: Central Statistical Office; data provided by Polish authorities; and IMF staff estimates.

$1 /$ Derived as total savings minus the current account minus capital transfers.

2/ Fund definition (including the cost of the pension reform).

$3 /$ Polish definition of debt including risk weighted stock of outstanding guarantees. 


\section{Statement by Andrzej Raczko, Alternate Executive Director for the Republic of Poland and Pawel Gasiorowski, Advisor to Executive Director April 16, 2008}

On behalf of the Polish authorities, we would like to thank staff for the constructive policy dialogue with the new government, which took place during the staff's visit in Warsaw. Although the new cabinet took office in the end of 2007, the consultations were held at a good time to exchange views about the prospects of the Polish economy and were helpful for the new authorities in the policy formulation process.

Our authorities share the staff's view that the Polish economy enjoys robust growth without domestic and external imbalances. Four years since the EU accession, the GDP growth rate has stabilized at a high level -exceeding 6 percent - and has helped Poland to speed up the real convergence process. Core inflation has been reduced to an acceptable interval of 2-3 percent. Moreover, the unemployment rate has fallen from 19 to 11 percent. The current account deficit, although increased, still remains at a safe level and is mainly covered by foreign direct investments and the inflows of EU funds. Strong economic fundamentals have a positive impact on the exchange rate. Therefore, the Polish zloty has been appreciating not only vis-à-vis the US dollar but against the Euro as well. Substantial progress has been made on the fiscal front. According to the information published in the last convergence program, the general government deficit reached 2 percent of GDP and the public debt was reduced to 44.9 percent of GDP (ESA95 methodology). Hence, both indicators satisfy the Maastricht Criteria.

\section{Outlook and economic developments}

Against this positive economic outlook, the key question is how much of the current pace of activity reflects deep structural changes in the economy and can be sustained over the medium term. In addition, the strong pick up in GDP growth will be tested by the worsening external economic environment. Both issues should be examined from the perspective of the macroeconomic and structural policies.

Our authorities share the staff's opinion that growth will slow down in the next years but the pace of adjustment allows for a soft landing. Hence, the growth rate will stay close to the path of potential output. The authorities expect that the real GDP growth will slow to 5.5 percent in 2008 and 5 percent in 2009 and 2010, which means that their projections are higher than the staff's estimations.

The authorities' expectations for 2008 are supported by the recent data. The retail sales have increased over 19 percent in real terms on a yearly basis in February 2008, and the unemployment rate has fallen by an additional 2.1 percent since January. The consumption demand, which is fuelled by still growing employment and an increasing wage bill, remains strong in 2008. Investments, which rose over 20 percent in 2007, are supported by increasing EU funds and robust economic prospects and are confirmed by growing business confidence 
indicators ${ }^{1}$. The impact on investment demand of a gradual tightening of monetary policy may be delayed because a substantial part of the projects is financed by the companies' own financial resources.

The impact of strong domestic demand on GDP growth will be partially offset by a negative contribution of net exports, which is larger than before On the other hand, although the Polish currency has been gradually appreciating since the EU accession, the market share of Polish exports has increased substantially and both exports and imports grew at two-digit rates. However, the positive foreign trade outlook may be changed in case of a substantial increase of unit labor cost or recession in the EU countries.

Our authorities agree with the staff's view that the current well-balanced economic growth may be at risk if supply side constraints, particularly tightening of labor conditions, and rising inflation are not reined in by an appropriate macroeconomic and structural policy mix. The National Bank of Poland is fully committed to bringing inflation back to the target. The new government announced fiscal plans aimed at reducing the public debt to GDP ratio by 4-7 percentage points and achieving a structural government deficit of 1 percent in 2011 .

\section{Monetary policy}

The average inflation rate was at a comfortable level of 2.5 percent in 2007 , while an increase of headline inflation in the last quarter of the previous year to 3.5 percent was mainly related to the global increase of food and fuel prices. A year ago the Monetary Policy Council (MPC) noted the increasing risk of medium-term inflation pick-up and began the tightening cycle. By March 2008, the MPC had raised interest rates by 175 basis points in seven steps. The MPC's decisions mitigated the growth of core inflation, which still remains at a relatively low level of 2.5 percent.

The rising headline inflation is currently driven by rising prices of food and oil in the global markets followed by the increase in energy prices. The external price shock is beyond control of the monetary authorities and may be partially offset by the appreciating exchange rate. Hence, the tight monetary policy may only anchor inflation expectations and target the second-round effects. However, if food and energy price shocks persist for a longer time, the risk of inflation entrenchment over the upper end of the inflation target band will increase. Against this backdrop, the monetary authorities assume in their projections a gradual bringing down of inflation to the target in 2010.

The monetary authorities share the staff's view that the main concern comes from the tighter labor market and the potential risk of igniting the wage-price spiral. Hence, the MPC is committed to a tight monetary policy stance until it is clear that inflation is returning to the

\footnotetext{
${ }^{1}$ The last report of the Domestic Commercial Chamber noted that 73.2 percent of Polish companies expected a substantial increase of sales while only 4 percent of them assumed a lower level of turnover.
} 
medium-term target. Taking into account the rising disparity of interest rates and large inflows of EU funds, the authorities expect a further appreciation of the zloty and a widening of the current account deficit in 2008. Even though the monetary authorities noted the cost of tightening the monetary policy (in terms of external balance deterioration), the monetary policy credibility, which is a corner stone of the inflation-targeting framework, needs a firm decision by the MPC.

Regarding the Euro adoption, the National Bank of Poland launched a new project to prepare an updated report analyzing the merits and risks of the Euro adoption. The report will benefit from the already progressing broad consultations with social partners, academia, business and the media.

\section{Fiscal policy}

According to the last convergence program submitted in March 2008, the general government deficit was reduced to 2 percent in 2007 mainly due to buoyant tax revenues and lower capital spending. The structural deficit was reduced from 3.7 percent in 2006 to 2.2 percent in 2007. Thus, Poland fulfilled the obligation to reduce the structural deficit by 0.5 percent, which was recommended by the EU a year ago. Our authorities are particularly satisfied with the surplus of 1 percent of GDP in the social security system. Also, the central government balance improved as the deficit was 1 percent of GDP lower than in 2006.

Despite the same level of central government fiscal balance (in terms of GDP) in 2007 and 2008, the general government deficit for the next year is projected to increase to 2.5 percent of GDP. The worsening of the fiscal stance is due to the cost of the reform of payroll taxation. The reform, which was necessary to cut the high tax-wedge and increase labor participation, has a substantial fiscal cost that exceeds 1 percent of GDP in 2008 and 2 percent in the next two years. In addition, the personal income tax rates starting from the fiscal year 2009 will be reduced.

As staff rightly pointed out, given the legal procedure of budgetary bill preparation, the new government did not have enough time to implement measures that might offset the cost of the payroll tax reform. However, some adjustments on the expenditure side have been implemented to reduce the planned central government budget deficit for 2008 by 0.1 percentage points. A more comprehensive program for restraining budget expenditure will be implemented in 2009. The authorities plan to lower the cost of the central and local governments by streamlining the administrative processes. Regarding social benefits programs, our authorities consider measures that should better target social programs without a nominal spending increase. The authorities see the merit of a rolling three-year budget recommended by staff, particularly implementing a more flexible system of planning EU funds expenditures. In this respect, our authorities welcome Funds' assistance in improving the budgeting process. 
In the medium-term perspective, our authorities plan to reduce the structural general government deficit to 1 percent in 2011. The ambitious 1 percent budget deficit is a de facto equivalent of a fiscal surplus. In 1999, Poland implemented a pension reform which gradually substitutes the pay-as-you-go system (FUS) by mandatory open pension funds (OFE) managed by private firms. The new capital-based pension system will significantly reduce the risk of the negative impact of population aging. On the other hand, the transfer from the pay-as-you-go system to the capital-based system brings about temporary fiscal cost. The cost equal to the difference between the social contribution paid by the workers and the expenditures in the pay-as-you-go pension scheme is being phased out. Therefore, the introduction of the new pension system has also two fiscal consequences. First, in the short term, the positive outcome of the reduction of the aging cost is not visible in the balance of the general government sector because the OFE's surplus is not regarded as a component of a public sector balance. Second, the negative outcome of the reform, i.e. transfers from the state budget to the FUS (estimated at the level of 2 percent of GDP), has a substantial impact on the current fiscal stance. Our authorities are committed to partially address this cost by limiting access to "bridge" pensions, which allow workers in some occupational categories to enjoy early retirement benefits. The list of professions will be restricted to people over 50 who are unable to perform their job until official retirement age due to special working conditions.

\section{Structural reforms}

The improvement of labor market conditions is a top priority of the authorities. As staff correctly pointed out, the increase of the very low labor participation ratio is a decisive element to sustain high GDP growth. Our authorities plan to implement measures that focus on increasing the employment of people over 50 ("Solidarity 50+" Program). Also, a decrease of the tax wedge will reduce pricing low-skilled workers out of the labor market. The introduction of degressive unemployment benefits is being proposed. The system of early pensions will be reviewed to limit schemes to health-related cases. These measures will be accompanied by a gradual equalizing of the retirement age of men and women. Moreover, a reform of a separate farmer's pension scheme (KRUS) is being discussed. In this respect, the authorities would like to increase the contribution of the owners of large farms.

The authorities are preparing a reform package to improve the effectiveness of public health care. The proposal for the new system was sent to social partners for consultation. The package includes the introduction of co-payments for health services and promotes greater participation in the voluntary health insurance.

Our authorities are fully committed to implement the EU product market regulations, especially the new services directive. The new government declared to reinvigorate the privatization process. Last but not least, the authorities plan to improve business confidence. In January 2008, a parliamentary commission called "Friendly State" was created, with the objective to eliminate the onerous administrative regulations and procedures that hamper the conduct of business. Currently, work is underway on the amendment of the act on 
accounting. A simplified tax and business law, reduced red tape and improved judicial procedures for settling business disputes will also be covered by the reforms.

The authorities will submit the National Reform Program for 2008-2011, whose main objective will be to boost labor productivity and improve competitiveness. The key element of the program will be measures to support the innovation and R\&D in high value added sectors and highly competitive industries. Moreover, the program will aim at providing competitive services and sufficient infrastructure in the network sectors.

\section{Financial markets}

The separate financial supervision authorities were consolidated into one office - the Polish Financial Supervision Authority (KNF). The long lasting consolidation has been completed by integrating the banking supervision with the KNF on January 1, 2008. The continuity of the vigilant banking supervision was maintained and the introduction of Basel II regulations is progressing. Despite some concerns noted in the staff's report, in the authorities' opinion the current supervisory activities and fulfillment of the statutory objectives by the KNF was not impaired by political influence.

The Polish banking sector has not been exposed to the sub prime credit crisis as the sector was virtually not exposed to mortgage-based structured products. The sector continues to be very profitable with a low level of non-performing loans and a very low recourse to securitization. Although there was a significant increase of mortgage lending in 2007, the level of total indebtedness remains low in relation to GDP and the rate of growth was still lower than the one of regional peers. It should be noted that the sub prime mortgage market does not exist in Poland and the borrowers are usually upper and middle income professionals. In the meantime, as a result of stabilization of the housing market in the fourth quarter of 2007 and tightening of lending standards in the second half of 2007, the demand for mortgage lending decreased.

However, recognizing the increasing share of long-term mortgages in the banks' portfolios, a significant majority of which is denominated in foreign currencies, the Commission for Banking Supervision (predecessor of the KNF) two years ago introduced a recommendation on good practices in mortgage-secured lending. The banks are recommended to run stress tests assuming a sharp depreciation of the zloty and a simultaneous interest rate increase. In effect, a borrower requesting a foreign currency denominated loan can obtain a smaller loan compared to a zloty denominated loan. Moreover, in March 2007 the Commission for Banking Supervision issued a regulation, which promoted more vigilant practices of banks' liquidity management. 